\title{
RECONSTRUCTING MEMORY: RECONSIDERING THE ORIGINS OF A LATE MEDIEVAL EPITAPH FROM WIENER NEUSTADT ${ }^{1}$
}

\begin{abstract}
The Christian Museum in Esztergom preserves an epitaph depicting the Death of the Virgin Mary. The panel painting, dated by its inscription to 1498, was ordered by Stephan Geinperger, then burgher of Wiener Neustadt, for his deceased wife, Dorothea Gerolt. The donor's name was for a long time misread as "Heinperger", thus hindering his identification. The correct transcription made it possible to reveal information about the person of the donor and detect his family and their kinship network in the contemporary written documents. Based on the inscription and the archival material in Wiener Neustadt, Knittelfeld, Nuremberg, Passau and other related towns, the lives of Geinperger and his wife could be reconstructed and a stepfamily could be identified. In addition, the original placement of the epitaph was determined as was the social topography of the related families in Wiener Neustadt, including their economic and social importance. Moreover, art historical analysis placed the painting in the artistic milieu of the wider region.

Keywords: kinship, gender, step family, university networks, economic relations, social topography, epitaph, panel painting, fifteenth century, Liebfraukirche, Wiener Neustadt, Knittelfeld, Passau, Nuremberg, Schwäbisch-Gmund, Memmingen, Vienna, Padua, Geinperger, Gerolt, Glockengiesser, Funk/Funck, Lower Austria, Christian Museum, Esztergom
\end{abstract}

\section{Introduction}

A painted wooden epitaph of large dimensions depicting the Death of the Virgin Mary and the donor's family is on display in the Christian Museum in Esztergom (Fig. 1). ${ }^{2}$ The painting is a memorial panel that was known in the previous literature as "the epitaph of Stephan Heimperger's wife". ${ }^{3}$ It had been documented for a long time as part of the former collection of the artist and art collector Blasius Höfel (1792-1863), long active in Wiener Neustadt. Consequently, it was considered - correctly, as it will be seen - to have originated in Wiener Neustadt. ${ }^{4}$ A considerable part of the Höfel collection was sold to Karl Lemann in Vienna ${ }^{5}$ in 1839, and there it was acquired by Arnold Ipolyi (1823-1886), bishop of Besztercebánya/Banská

\footnotetext{
* Judit Majorossy PhD, Institute for Austrian Historical Research, University of Vienna; e-mail: judit.majorossy@univie.ac.at Emese Sarkadi Nagy PhD, Christian Museum, Esztergom; e-mail: sarkadie@gmail.com
}

Bystrica (1871-1886) and later of Nagyvárad/Oradea (1886). A few decades after the bishop's death in Nagyvárad, his collection, together with the epitaph in question, arrived in the Christian Museum in Esztergom. ${ }^{6}$

The painting shows the Virgin in the centre of the composition, lying with closed eyes on her deathbed. The elegant bed has a red baldachin and a brocadedecorated headboard painted in gold and dark green. The dying mother of God is covered with the same type of brocade. The bed is surrounded by the twelve apostles. A window can be seen on the right side of the image, its opening filled with a golden brocade pattern. The composition of the whole painting, the arrangement of the figures in the room, follows in the smallest details an engraving (Fig. 2) dated to 14701474 by Martin Schongauer (c. 1445/1450-1491). The only difference between the two works is the missing candelabrum in the foreground. Its omission was necessary in order to place the small-sized donors and the members of the family at the bottom of the 


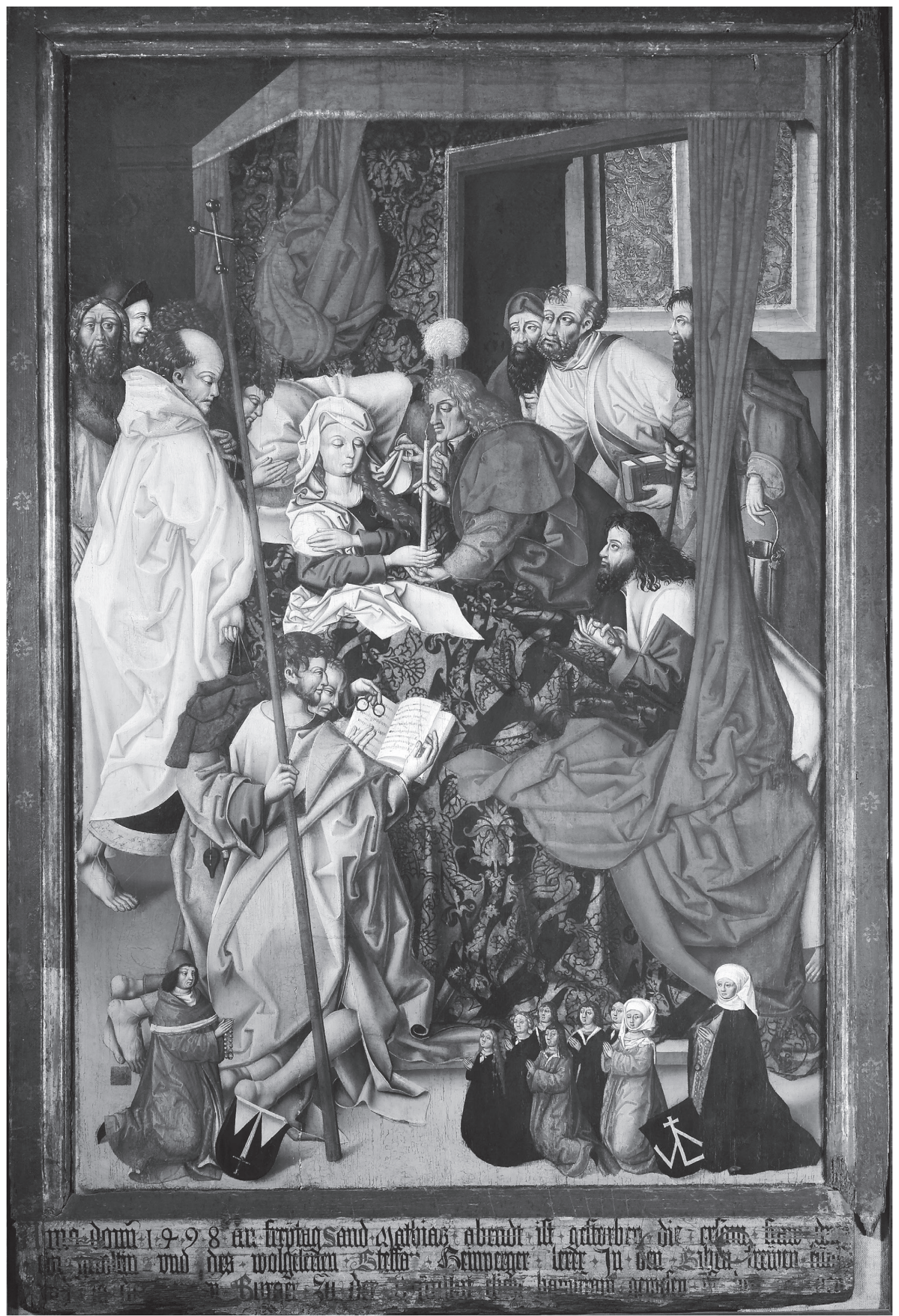

Fig. 1. The Geroltin epitaph; Esztergom, KM, inv. no. 56.509 (photo: Attila Mudrák, Esztergom Christian Museum) 


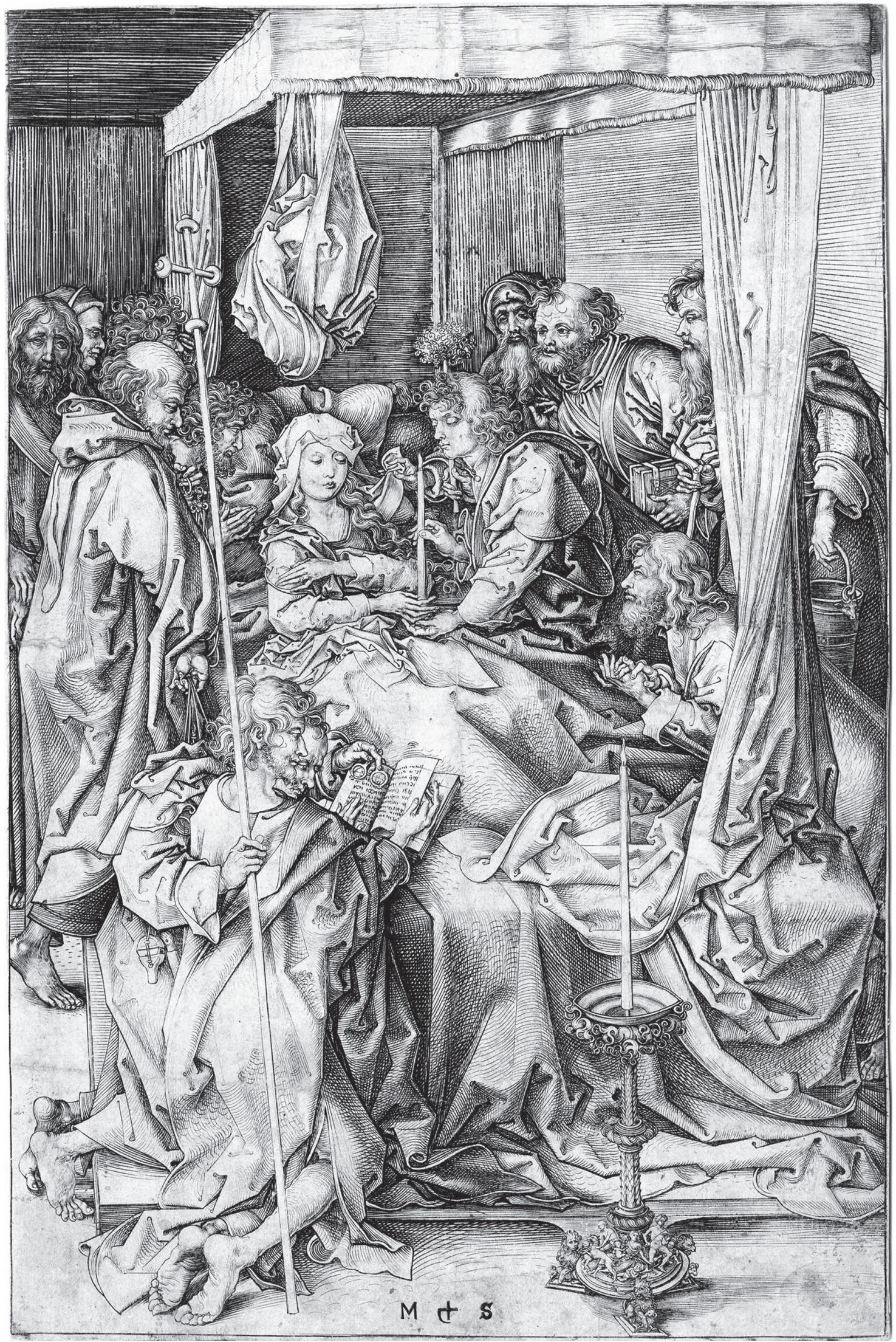

Fig. 2. Martin Schongauer's Death of the Virgin used as a pattern for the Geroltin epitaph; London, BM, inv. no. 1868,0822.153 (photo: London British Museum) 
image. On the heraldic right-hand side (Fig. 3), at the feet of two apostles, a man (the husband) is depicted kneeling, with his hands clasped in prayer, holding a short string of beads, a rosary. He wears a red mantle with a white fur-edged collar and a red academic cap (biretta) on his head, both types of clothes alluding to university studies. ${ }^{7}$ In front of him is a heraldic shield presenting a silver double-edged long dagger (bicellus $)^{8}$ in a dark, piled composite (damask) field, with its tip between two identical, hanging golden spikes or wedges. The shield itself is carefully depicted, giving the impression of a real object with a shadow, its recurving upper edge also casting its own shadow. Opposite the male figure, on the heraldic left (Fig. 4), a woman (the wife) is kneeling in prayer, holding a long rosary between her clasped hands. She is wearing a red dress that is almost completely covered by her black cloak and, indicating her married status, a white headdress (with a typical medieval veil). In front of her is another heraldic shield displaying a golden house mark (Hausmarke) $)^{9}$ on a dark field. All seven of the children, both girls and boys, are kneeling in front of the woman and only two of them are wearing red robes while the rest are presented in black. One of the children in red, a daughter, also wears a veil, indicating that at the time the painting was made - according to its inscription in 1498 - she was already a married woman.

In the upper left - now rather dark - corner of the painting, the careful observer will notice the ciphers 1498 , directly under the profiled cornice of the room's back wall. In the corner of the room, beneath the ciphers hangs a carved replica of a shield showing the same coat of arms with the dagger as seen in the escutcheon in front of the kneeling male figure. The panel painting is preserved in its original frame. The lower board contains the inscription that allows us to identify the epitaph and the individuals represented in it:

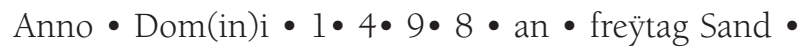
Mathias $\bullet$ abendt [13 Mai] $\bullet$ ist $\bullet$ gestorben $\bullet$ die $\bullet$ ersam $\bullet$ fraw $(\bullet)$ Do[rothea] // [e]in $\bullet$ Geroltin $[\bullet]$ vnd $[\bullet$ des $\bullet$ wolgelërten $\bullet$ Steffa[n] $\bullet$ Geinperger $\bullet$ lerer $\bullet$ in $\bullet$ den $\bullet$ siben $\bullet$ frewen $\bullet[k]$ ün[sten] // [v]nd $\bullet$ in[n] - de[r] [artzney/ertzney $]^{10}[\bullet]$ Burger $\bullet$ zu $\bullet$ der $[\bullet]$ $\mathrm{N}[$ e] ünstat $[\bullet]$ eli $[\mathrm{ch}]$ e $[\bullet]$ hawsfraw $\bullet$ gewesen $\bullet$ ist $\bullet$ de[r Got] $\bullet \operatorname{gen}[\mathrm{ad}]$.

There are only a few known surviving examples of late medieval epitaphs from Wiener Neustadt, and only a small number of them are for women. ${ }^{11}$ Thus, our

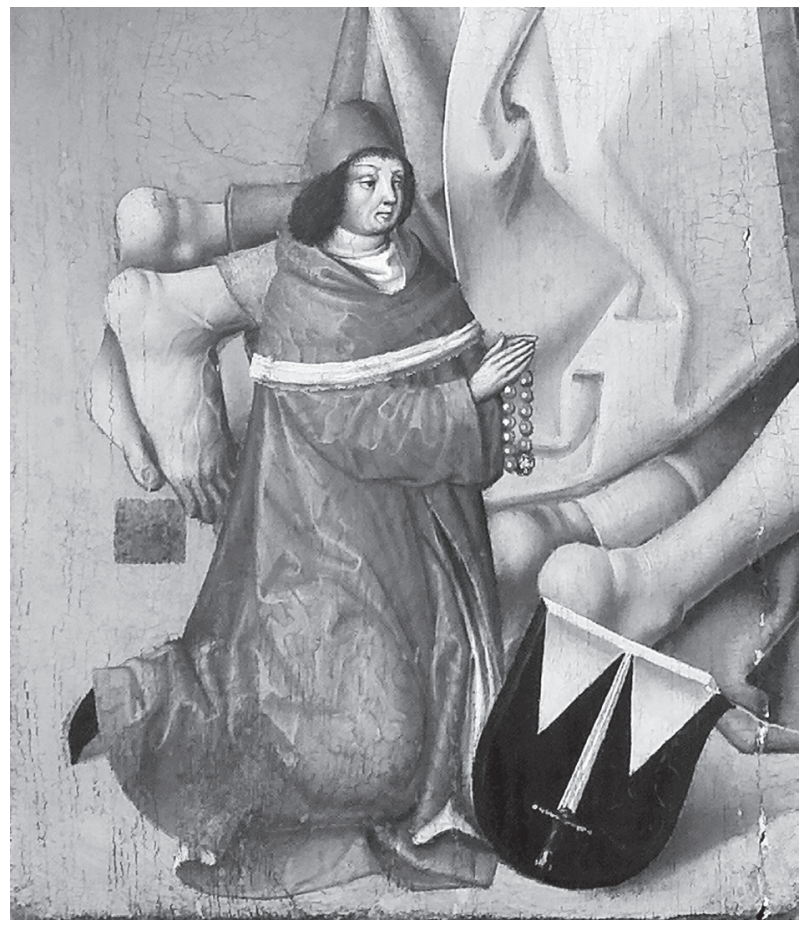

Fig. 3. Stephan Geinperger - detail of the Geroltin epitaph; Esztergom, KM, inv. no. 56.509

(photo: Attila Mudrák, Esztergom Christian Museum)

intention is to provide a complex and interdisciplinary investigation of this artwork, especially given some of its striking features; its exceptional dimensions, the dominance of the husband's attributes in an epitaph for his wife, the method in which information about the deceased woman is provided, and its style, which does not conform with other paintings attributed to late fifteenth-century Wiener Neustadt workshops.

With regard to its artistic qualities, this epitaph fails to distinguish itself from other known paintings of the time from Wiener Neustadt. Nevertheless, it possesses several seemingly insignificant but rather notable features that inspired us to further explore the social context in which it was ordered and made, a line of research that promised to be more fruitful. Who were these people depicted in the epitaph? Why are we confronted with an unusual arrangement of male and female children? Can we ascertain the donor's intentions concerning the style, arrangement and nuances of the image? How does this epitaph fit in with the religious practices of the families involved? Can we determine its original location within the church where it was displayed? Does the social position of the urban woman represented explain the large size of the epitaph? How do we reconcile the late fifteenthcentury date provided by the inscription and the old- 


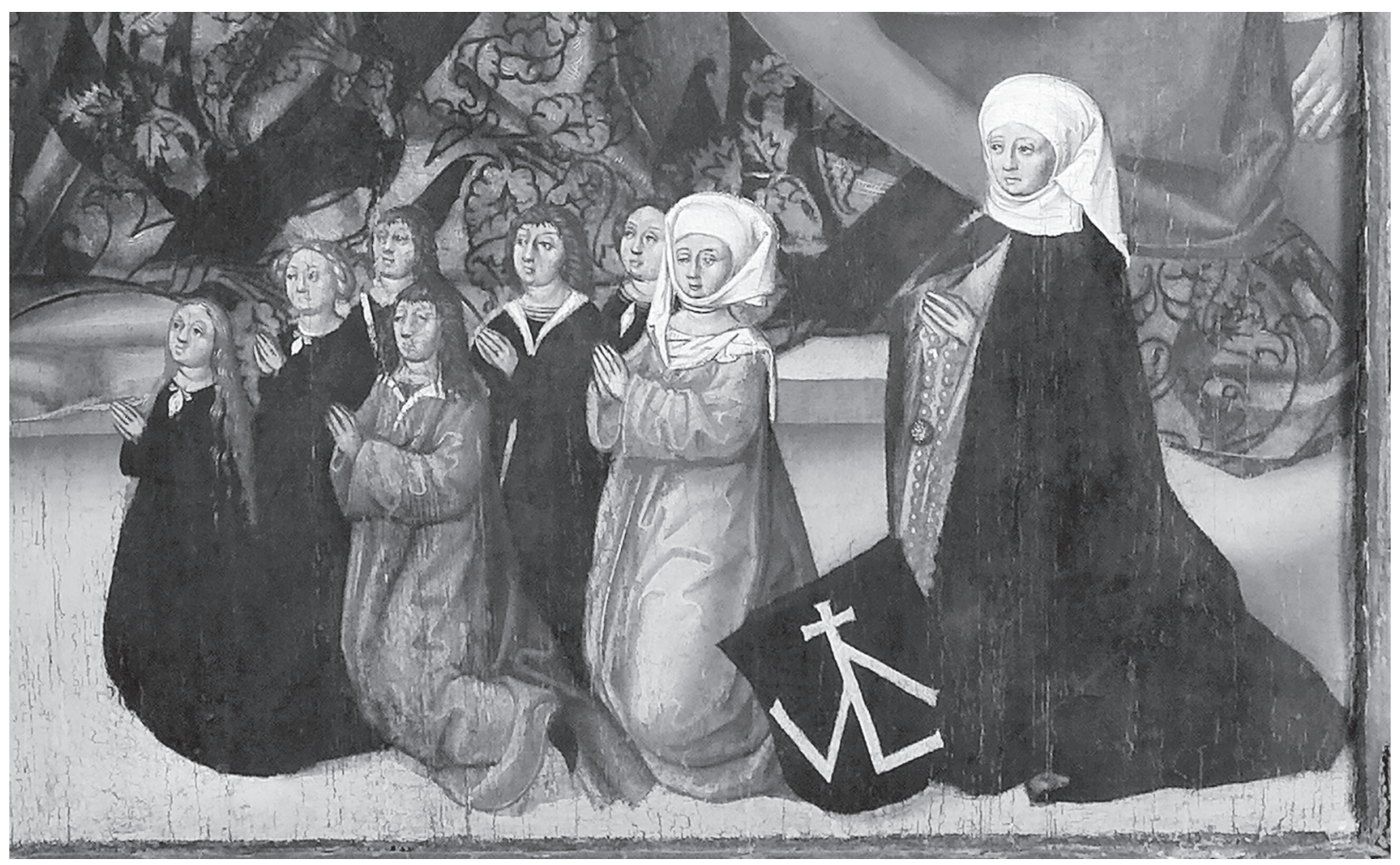

Fig. 4. Dorothea Gerolt with children - detail of the Geroltin epitaph

Esztergom, KM, inv. no. 56.509 (photo: Attila Mudrák, Esztergom Christian Museum)

fashioned style of the painting? These questions are what inspired us to embark on our investigation.

Although the latest short description of the epitaph summarized a few things about Stefan Geinperger, ${ }^{12}$ the scholarly literature so far has left the family background essentially untouched, and no attempts have been made to contextualize the painting itself. Our aim, therefore, was to investigate both the historical and art historical context of this artwork as well as to reveal the wider geographical framework (Fig. 15) and the family's kinship history (Fig. 16) by bringing together a collection of available source material and information from the scholarly literature that had never been used and cited in connection with this epitaph, although it had been applied to related matters.

\section{The historical context of the epitaph}

The starting point for our research was the abovequoted text on the frame of the epitaph. The way in which the inscription refers to the deceased woman is striking, even at first glance. Before she is identified by her - as it will be proven, second - husband, his occupation and citizenship, she is declared "eine Geroltin". For the medieval urban audience reading this text on the epitaph in the parish church, such reference to her family background must have been meaningful, and for the widowed husband who was most probably charged to complete the epitaph, it seems to have been rather important to highlight his wife's kinship. Does this mean the Gerolt/Gerold ${ }^{13}$ family was well known within the Wiener Neustadt urban community or at least rather influential at that time? An additional question that arises in connection with the text and the image in the epitaph is the personality of the widower himself. Consequently, after the geographical, social and economic network of the female side, the Gerolt family, is discussed together with a few facts revealed about the religious life of the family members, we will turn our attention to the male side. The "biography" of the husband(s) will be presented as well as a reconstruction of the men's "physical" (topographical) and social position in the life of the late fifteenth-century Wiener Neustadt.

\section{The Gerolts of Knittelfeld}

The Gerolt family network expanded from Styria to Swabia (NW) and to Wiener Neustadt (NE) basically through the iron trade (Eisenhandel). ${ }^{14}$ The original 


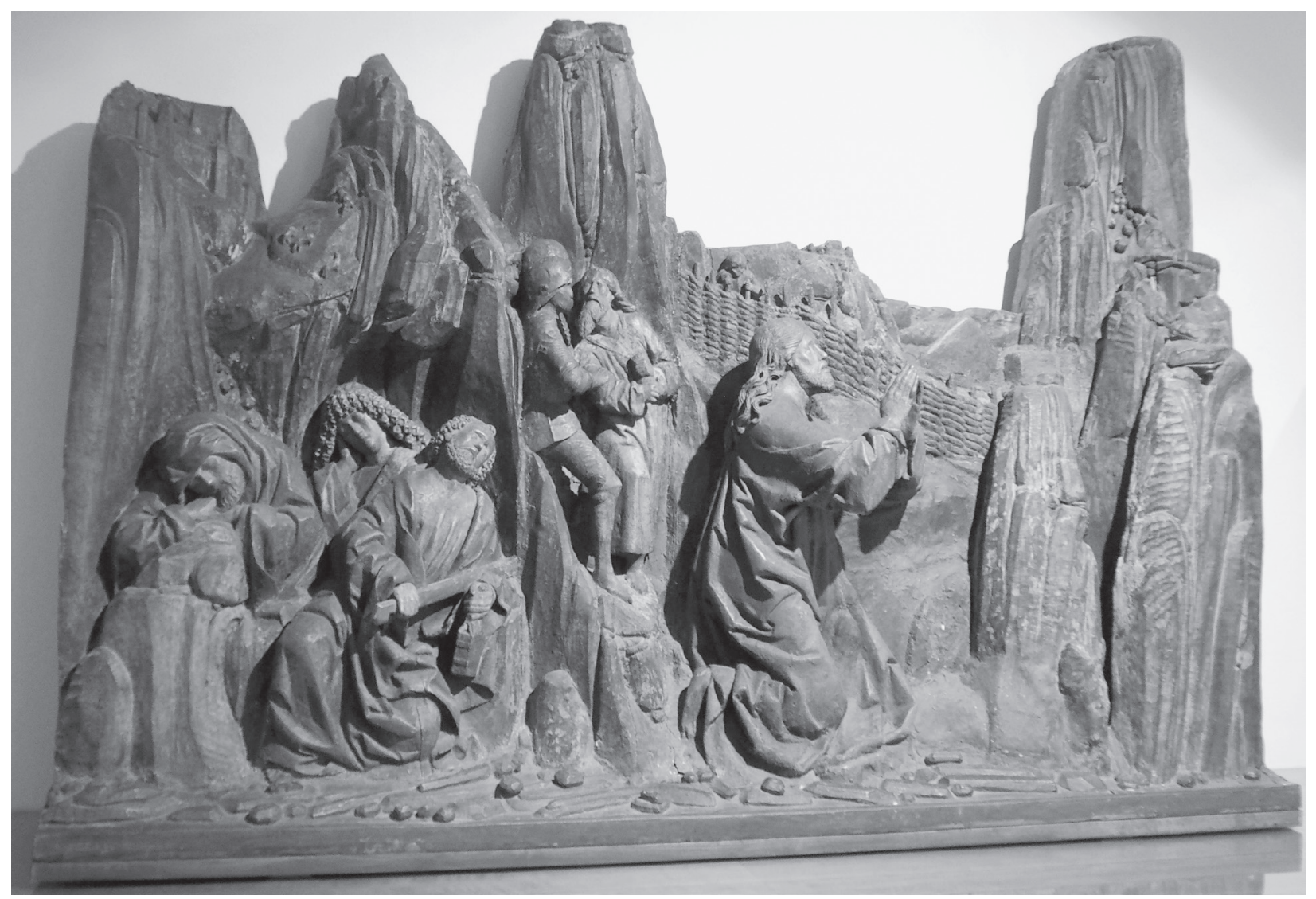

Fig. 5. The wooden relief of Christ's Agony in the Garden of Gethsemane, in the parish church of St John the Baptist in Knittelfeld (photo: Judit Majorossy)

residence of the kin (Geschlecht) was the small ducal town (landesfürstliche Kleinstadt) of Knittelfeld, situated a few kilometres away to the north of Judenburg, which benefited from its iron ore smelting, forging and trading opportunities. This defining economic background is well represented in a late Gothic wooden relief showing Christ's agony in the Garden of Gethsemane, which was originally placed by the chapel of St Catherine $^{15}$ in the local parish church. The terrain depicted in the background reminds the viewer of the iron-rich mountains of the region (Fig. 5). ${ }^{16}$ The Gerolts belonged to the highest circle of the old and influential burgher families of Knittelfeld, ${ }^{17}$ and they frequently appear in discussions of the economic, trade and social context of medieval Styria. ${ }^{18}$ Knittelfeld itself was located along the Venedigerstrasse ${ }^{19}$ which headed through Villach and Wiener Neustadt towards Vienna, branching further on in different directions (Fig. 15). Although it was a rather small town in the overwhelming shadow of Judenburg, ${ }^{20}$ through its participation in iron production and trade by the mid-fifteenth century it - or at least a few of its patrician families - was able to benefit significantly from the economic wealth generated along the Venetian road. Knittelfeld - whose name first appeared in a charter in 1224 and whose earliest known seal is from 1288 - was established by the duke of Babenberg, Leopold VI of Austria and Styria "the founder of the town", but it received significant support from Duke Rudolf III of Habsburg, who granted it all the rights of the neighbouring Judenburg21 in 1302. Later, several other rights were conferred on the settlement, among them the right to levy tolls and taxes (1344) and have its own court day (1365) as well as further privileges granted by Frederick III, such as the right to administer criminal justice (Blutgerichtsbarkeit, 1447), hold weekly markets (1447), sell wine (1453) and eventually distribute it in the neighbouring settlements (1476). Nevertheless, the burghers were not able to elect their own town judge until the late date of 1476. Previously, the judge and the Ratsfreunde had been appointed by the duke. A little over a decade later, a member of the Gerolt family (Valentin Gerolt, 1489/1490) was elected to this position. ${ }^{22}$ Soon enough, the urban hospital - dedicated to St Anthony and later to St Leonhard - and the parish school (first mentioned in 1471) were also established. ${ }^{23}$ Most 
likely, those first Gerolt family members, namely the brothers of Dorothea Gerolt who had pursued university studies in Vienna in the 1470s, were among the first students to have attended this local parish school.

"Jacobus Gerold von Chnuttlveld", who later (between 1479 and 1492) was the parish priest of Knittelfeld, ${ }^{24}$ matriculated together with his brother, Bernhard, in 1472 (14 April) and both received baccalaureus artium degrees in 1475 (2 January). Jakob himself also achieved the title magister artium in 1478 (3 March), 25 and after his university years in Vienna, he first returned to Knittelfeld, where he certainly became the priest of the local church (1479). ${ }^{26}$ However, later he continued his studies in law, and by 1484 he was already at the university of Padua, ${ }^{27}$ where he was then appointed as rector of the law faculty $(1487-1488){ }^{28}$ During his time in Italy, a vicarius ${ }^{29}$ must have filled in for him in Knittelfeld, since in his correspondences he still used his title as the parish priest of the church of St John the Baptist in Knittelfeld. ${ }^{30}$ As part of the local elite and also university educated, he prepared several land conscription registers ${ }^{31}$ during his time in office in Knittelfeld. In them, he documented not only the urban properties of the inhabitants of this market town but also recorded several details about Dorothea Gerolt's many brothers and sisters, together with the significant altar and perpetual mass foundations established during the 1440s and 1480s. ${ }^{32}$ Similarly, it was Jakob Gerolt who in 1489 noted that "der paw der pharrkirche zu gut maßen vollbracht", 33 which also indicates that he actually took an active part in initiating and conducting construction works. The documents suggest that Dorothea's brother, the priest lived his final days in the Augustinian (Austin) canonry of Seckau (in 1492 he was mentioned as a provost there) but was finally buried in his hometown, although the date of his death is unknown. ${ }^{34}$

The town's heyday, however, must have come to an end by the late-fifteenth century for several reasons, among them the attacks and destruction carried out by Ottoman raiders in the outskirts (1480) and a great fire (1510), events recorded by Jakob Gerolt himself in one of his liturgical books, in a Missal (Fig. 6-8). ${ }^{35}$ Other contributing factors were a severe locust invasion (1477/78) and the ensuing famine as well as repeated outbreaks of the plague (in 1461, 1466, 1481, and later also in 1495). ${ }^{36}$ Nevertheless, before the decline of the market town, both the Gerolt family and the settlement had certainly played an integral role in the trade of iron and iron products. ${ }^{37}$ The family's forefathers had mines around Knittelfeld and were involved in iron processing itself, as documentation of their ownership of iron hammers (Hammerhaus, Hammer) and sledgehammers (Streckhammer) from the mid-1440s onwards indicates. ${ }^{38}$ The later generation seemingly also took part in other trades, especially meat and leather. ${ }^{39}$ Consequently, the family intermarried with several important merchant families in the wider region. Generally, it is interesting to investigate the family's kinship network, as far as it can be established from the investigated sources. In the town itself, the Gerolts and the Muerers belonged to the most influential old families, ${ }^{40}$ and they also established family ties with one another (Fig. 16). Of the generation active in the 1430s-1450s, Gotthard Muerer (ratsfreund 1434, whose house mark of 1442 has survived) and Jakob Gerolt the Elder (first mentioned in 1435, owner of the documented iron foundry in 1445) might have been brothers-in-law. ${ }^{41}$ The house mark (Fig. 9A) shown on the female side of Dorothea Gerolt's epitaph ${ }^{42}$ might date to this generation of the family. The offspring of Jakob Gerolt the Elder, Leonhard/Lienhart - and probably also his brother, Hans - already had strong ties to Wiener Neustadt, as Leonhard had taken Margaretha of the Werdl family as his wife (Fig. 16); her father, Hans (I) Werdl, was a member of the Wiener Neustadt merchant guild. ${ }^{43}$ In a wider context, Leonhard had business contacts mainly with Bavaria at that time as well. In 1477, Emperor Frederick III's attention was drawn to Augsburg because of a claim by the widow of Leonhard Gerolt, ${ }^{44}$ burgher of Knittelfeld in Styria against a burgher of Augsburg (Jakob Bodsund) concerning a steel delivery. ${ }^{45}$

Because of his economic contacts, Leonhard Gerolt and his sons managed to widen the family's network through the marriages of their children. According to the data gathered from the sources, Leonhard had three daughters (Dorothea, Anna and Elisabeth) as well as four sons (Bernhard, Andreas, Valentin and Jakob) (Fig. 16). As we have seen, Jakob Gerolt chose an ecclesiastical career, but his brothers continued the family business in Knittelfeld. ${ }^{46}$ They took an active part in the social, political and ecclesiastical life of the town; Jakob as the parish priest and Andreas as the church warden (czechmaister Sand Johanns pharrchirchen) during the same period, ${ }^{47}$ while Valentin as town councillor and later also town judge (1489/1490). ${ }^{48}$ Around the turn of the century, however, Valentin moved to Judenburg, where he most probably married a member of the Anngrer family. Once he had obtained citizenship (sometime around 1492), ${ }^{49}$ he also became the town judge of Judenburg 


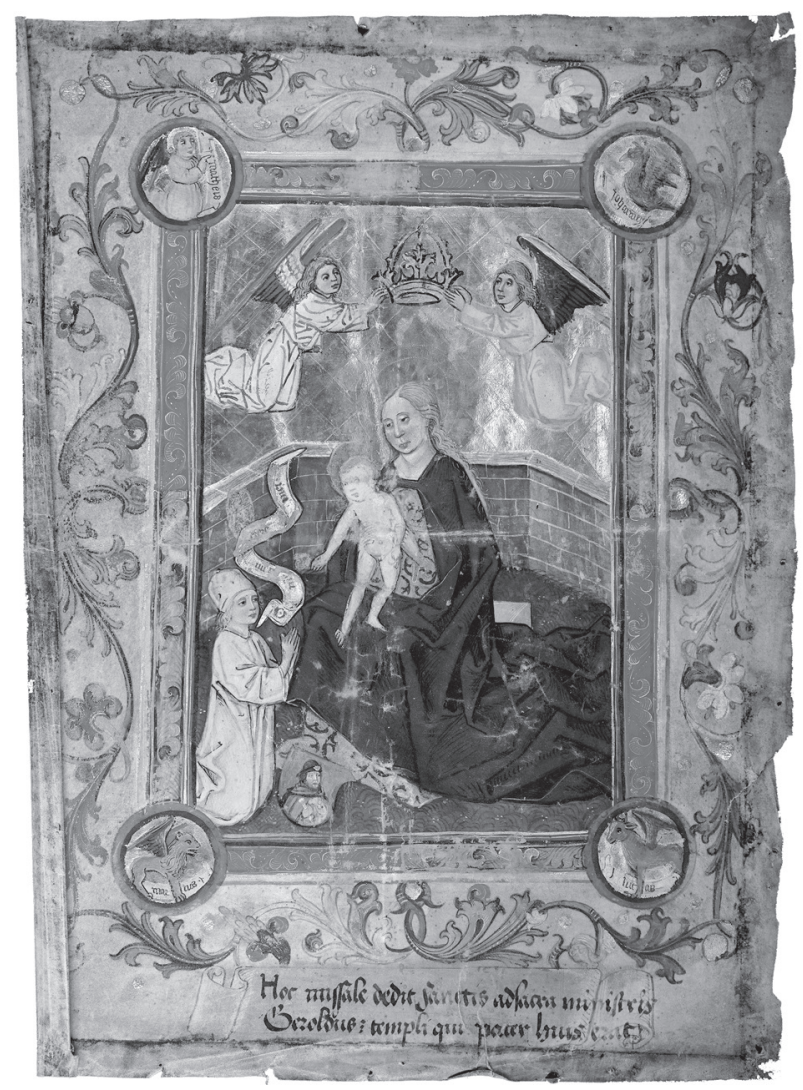

Fig. 6. The cover page of the missal once owned by Jakob Gerolt; Graz, UB, MS 74, fol. 1r (photo: Graz Universitätsbibliothek)

in $1503 / 1504 . .^{50}$ Afterwards he either left the town or died, since he disappeared from the sources. ${ }^{51}$

The sisters of this generation, however, married away from their hometown. Details about Dorothea's marriage(s) will be discussed later; here it should be noted only that with her marriage (sometime in the 1470s), she moved to Wiener Neustadt. Her younger sister, ${ }^{52}$ Anna, might have lived for a while in Knittelfeld, as she still had landed properties there in 1489, ${ }^{33}$ but around 1495, a long-distance merchant company member, Hans (II) Funk of Memmingen, took her as his wife. ${ }^{54}$ In addition, according to the secondary literature, Dorothea's other sister, Elisabeth, also married a Funk, a certain Rembold. ${ }^{55}$ The Funk company (officially established in 1495) was formed mainly from the members of the Funk/Funck trading family originating from Schwäbisch Gmünd. They were simultaneously involved in businesses in Augsburg and Nördlingen and also in Austria, partially in the region of Knittelfeld/Judenburg and mainly in Wiener Neustadt. ${ }^{56}$ Andreas Funk (died 1506) led the company between 1495 and 1499, but he had already owned a trading house in Styria, in Murau in 1494, where he had stored steel. ${ }^{57}$ It was his nephew, Hans (II) Funk (died 1513), who took over the leadership of the company. Hans first married locally but then took Anna Gerolt as his second wife and also became strongly involved in the steel and iron trade. ${ }^{58}$ In the early years of the sixteenth century, he appeared in Wiener Neustadt, ${ }^{59}$ where his brother Alexius (died 1521) had already been living for decades because of his role in the family business ${ }^{60}$ and had become a renowned personality. ${ }^{61}$ In 1497, Alexius had married Margarethe, the daughter of Hippolyt Steiner, whose family already had kinship ties to the Gerolts. ${ }^{62}$ The Funks had their own family chapel in the church of St Martin in Memmingen, where an epitaph of Hans (II) Funk and Anna Gerolt was displayed (Fig. 10). ${ }^{63}$ Like the Gerolts, the Funk family made their fortune in the iron trade, but their company also exported cloth to Austria, salt to Switzerland and wine to several lands. From Venice, the company imported nonferrous metals, spices and other goods. The family was present in the iron-towns of Styria, in Vienna, Buda, Wiener Neustadt, Linz, Nördlingen, Augsburg, Frankfurt, Salzburg, Schaffhausen, Zurich, probably Basel, and Northern Italy. Alexius Funk also had ties to the imperial court of Maximilian I. ${ }^{64}$ The kinship ties between the Funks and the Gerolts continued during the early sixteenth century; Wilhelm Funk moved first to Knittelfeld, he was burgher there between 1517 and 1519 and later moved to Radkersburg. ${ }^{65}$ Another relative, Hans Rembold Funk, married one of the granddaughters of Leonhard Gerolt, Elisabeth, in 1535. ${ }^{66}$ Two years later, Leonhard Gerolt the Younger - most probably the son of one of Dorothea's brothers $^{67}$ - took Margaretha Gienger from Ulm as his wife and was finally accepted into the closed circle of the urban patrician families (Geschlechtergesellschaft) of Memmingen, since the already named Hans Rembold Funk had paid the entrance fees for him even though he remained a guest and did not become a member of the Burghers' Guild (Großzunft) itself. ${ }^{68}$

More information is available on the religious life of the Gerolt family in Knittelfeld than on any other families in the town thanks to the already mentioned missal of Dorothea's brother, Jakob. ${ }^{69}$ As the parish priest of the community, ${ }^{70}$ Jakob Gerolt noted all the important perpetual masses in the calendar part of the missal (Fig. 7), ${ }^{71}$ numbering them and providing a detailed description of each on empty pages at the end of the manuscript (Fig. 8). ${ }^{72}$ Many of these obligations on the anniversaries of deaths were related to his own family members, especially to the deceased parents. ${ }^{73}$ In addi- 


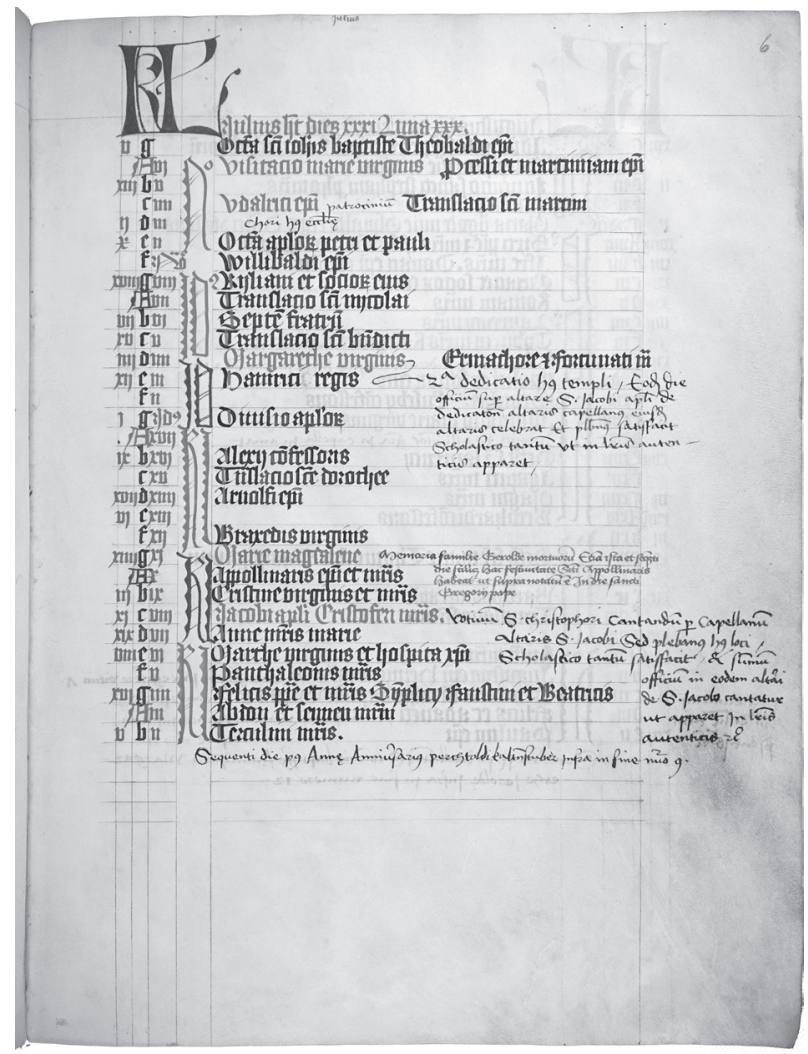

Fig. 7. A page of the missal of Jakob Gerolt with notes on perpetual masses in the calendar; Graz, UB, MS 74,

fol. 6r (photo: Graz Universitätsbibliothek)

tion, on the first folio of the missal, a devotional picture shows him as a donor kneeling in front of the Virgin. ${ }^{74}$ In Knittelfeld, the altar, chapel and eternal masses founded by the Muerers and the Gerolts are the best documented, ${ }^{75}$ and until the early nineteenth century a few family gravestones - that of the father Leonhard and the priest Jakob - were also preserved there. ${ }^{76}$ The family established a significant foundation in the parish church of St John the Baptist of Knittelfeld in 1489. All the living children of Leonhard Gerolt, including Dorothea, commissioned together the construction of an altar in honour of Sts James (the Apostle), Christopher (the martyr), Leonhard and Wolfgang, and All Saints in the church by the column standing opposite the pulpit. ${ }^{77}$ In addition, the children ordered several perpetual masses to be performed at the altar: first of all, a chaplain was commissioned to sing the matins (Frühambt), then a mass was to be sung on the anniversary day of the consecration of the altar, another one on the Monday after the octave of Easter, which was the anniversary of the founder's - the father, Leonhard Gerolt's - death (Jahrtag) and finally one on the Monday following the feast day of the church patron, in memory of the mother, Margaretha. From the text, it is

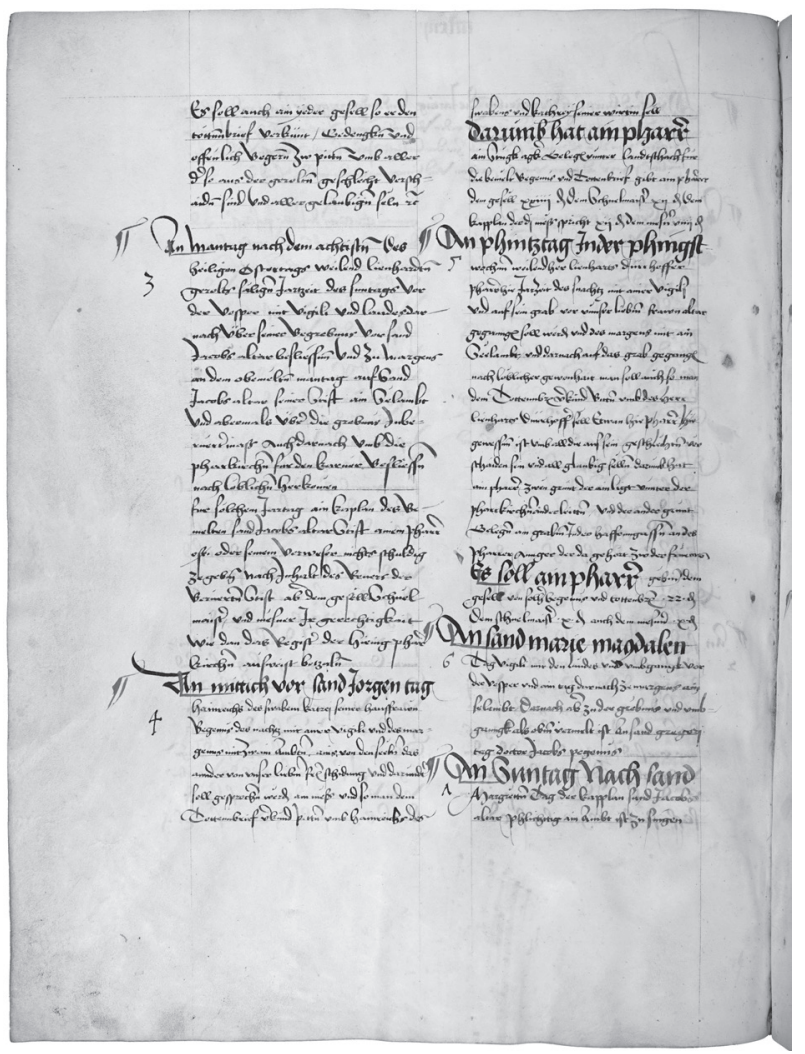

Fig. 8. Another page of the missal of Jakob Gerolt with additional notes on the mass foundations; Graz, UB, MS 74, fol. 359v (photo: Graz Universitätsbibliothek)

also clear that the parents were buried close to the altar, and there on Sunday evenings, before the given dates, a vigil was to be sung before vespers and after lauds. Afterwards, on Mondays the chaplain, the schoolmaster and the sacrist would make a procession with the Corpus Christi to the parish cemetery by the town walls (to the charnel house). This whole process was then to be repeated on the feasts of Sts James, Wolfgang and Leonhard. The charter also explains that Jakob Gerolt used the family's legacy to renew and enlarge the parsonage (Pharrhof) situated next to the parish cemetery, and in this complex, a prebendary house (room) was also built for the altar priest.

In addition, the family members were also present in the oldest - and most probably rather elite - confraternity of Knittelfeld, the Corpus Christi brotherhood. ${ }^{78}$ Its preserved Raydt-Register (containing the membership lists and several accounts of the confraternity) was written in a booklet bought in Venice by a family member in 1477 , as indicated by the presence of the family house mark (see Fig. 9B-C) visible both on the edge and on the verso of its cover. ${ }^{79}$ The Corpus Christi confraternity must have also played an important role in the religious life of Dorothea Gerolt herself in 


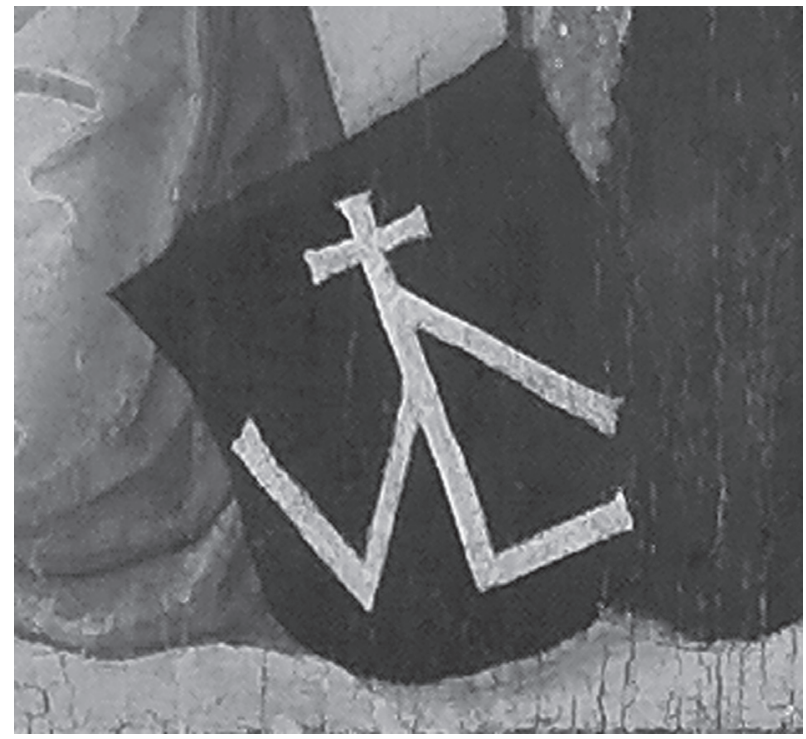

A: The Geroltin epitaph

(photo: Attila Mudrák, Esztergom Christian Museum)

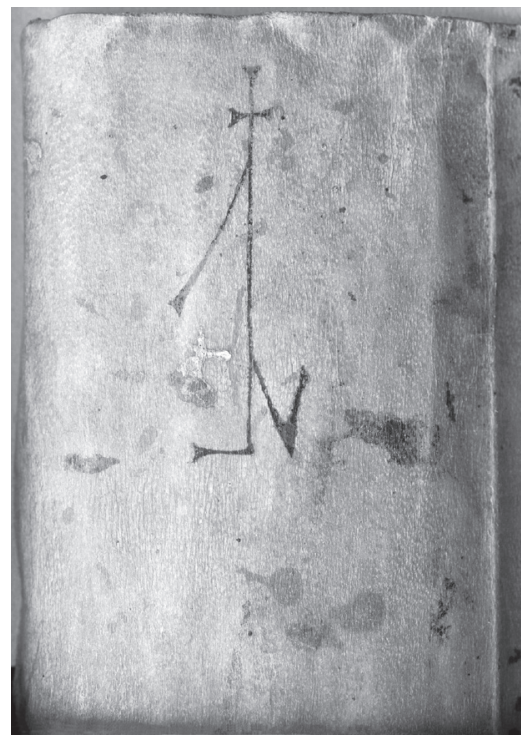

B: The Corpus Christi confraternity register of Knittelfeld (photo: Graz Steiermarkisches Landesarchiv)

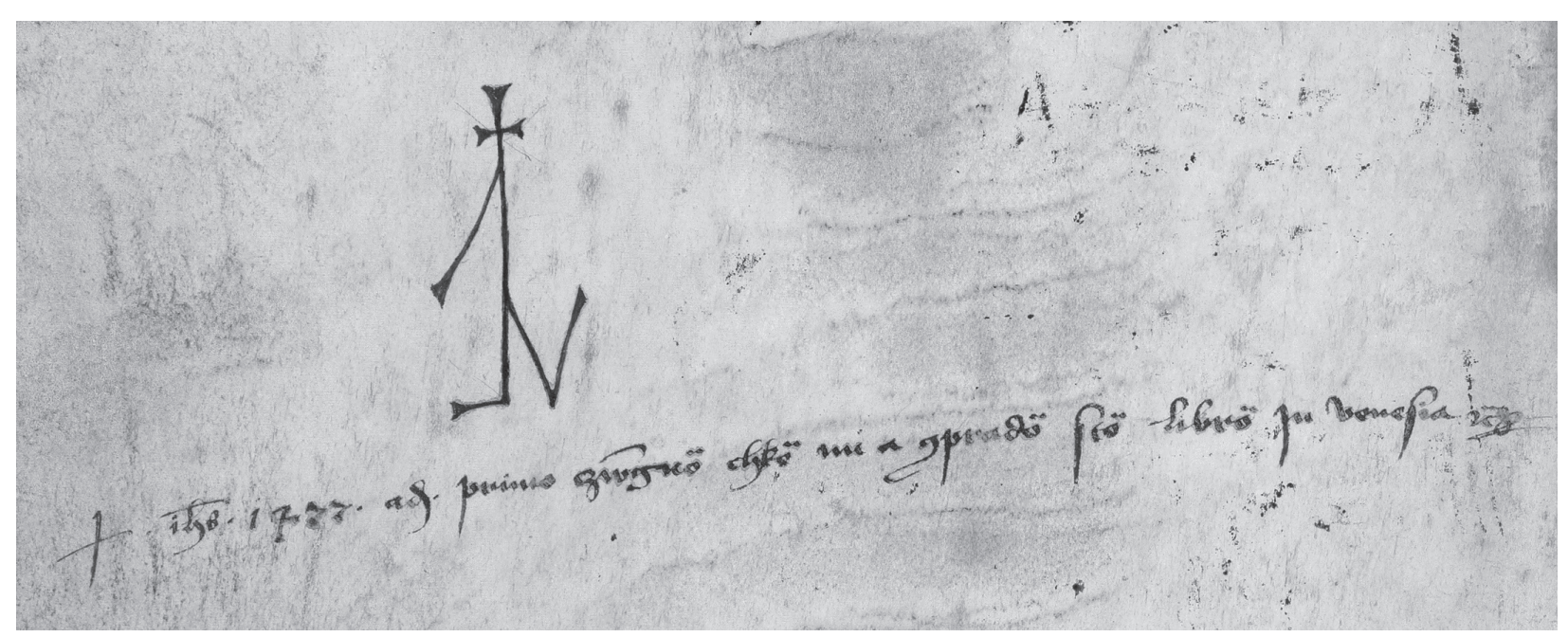

C: The Corpus Christi confraternity register of Knittelfeld (photo: Graz Steiermarkisches Landesarchiv)

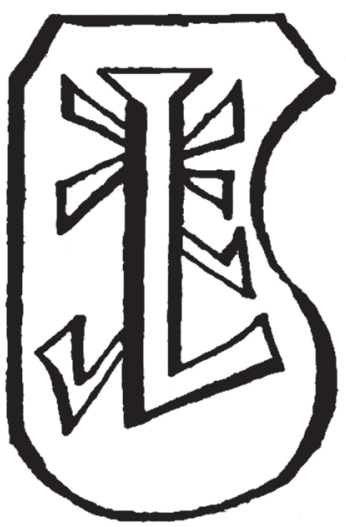

D: The gravestone carving of Jakob Gerolt (published: SONNTAG 1844, 70)

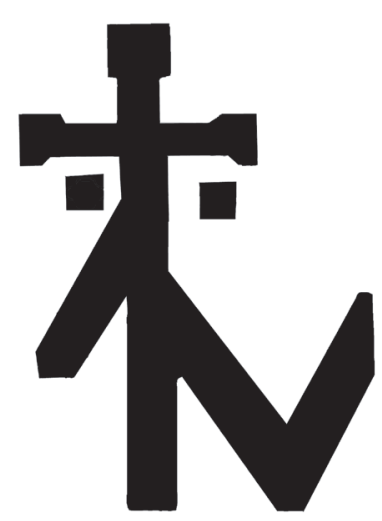

E: The seal of Andre Gerolt, the judge in Judenburg (published: Mell 1896, 26)

Fig. 9. The Gerolt family house mark identified on different artworks of the fifteenth century (see note 42). 
Wiener Neustadt, since both her husbands were also members of the Fronleichnamzech there. ${ }^{80}$

As demonstrated, the Gerolt family must have played an extensive, multifaceted role in the wider region through their involvement in iron production and regional trade. Their business activities even helped them to secure connections to the imperial court in Wiener Neustadt, and the family was obviously well established in the local and regional social milieu. Contemporary families of the same social rank, therefore, would have found it desirable to form kinship relationships with the Gerolts through marrying the daughters of the family, as seen, in the immediate region (the Muerers, the Werdls and the Steiners) and in more distant lands (the Funks) connected through trade routes. Consequently, as the example of Dorothea will show, the Gerolt daughters might also have been considered marriage prospects for families from even greater distances which were less well-connected through trade, who were looking to establish kinship ties to Wiener Neustadt.

\section{Dorothea Gerolt and her husbands in Wiener Neustadt}

As demonstrated above, through their kinship and also through their economic networks, the Gerolts were present in Wiener Neustadt, too. On the one hand, as the few early facts about the members of the Gerolt family prove, a certain Hans Gerolt of Knittelfeld moved there around the end of the 1440s. ${ }^{81}$ He might have been a brother of Leonhard Gerolt, the father of the "epitaph-owner" Dorothea Gerolt, but no direct evidence could be found to prove the exact character of their relationship. On the other hand, as mentioned earlier, the father, Leonhard Gerolt, married a certain Margaretha, ${ }^{82}$ a daughter of the Werdl merchant family, also from Wiener Neustadt. ${ }^{83}$ In the last will of Hans Werdl the Younger, it is stated that his niece's husband was a certain Hans Glockengiesser. ${ }^{84}$

But who was this niece he refers to? It was the daughter of Hans Werdl's sister, the subject of the epitaph, Dorothea Gerolt. This fact, however, can be reconstructed from a much later note in the Gewährbuch of Wiener Neustadt, which refers to Stephan Geinperger and his wife, Dorothea (Gerolt, as it is known from the epitaph), who at that time took possession of a certain corner house situated in the Neunkirchnerstrasse (Fig. 17). The relevant entries concerning the history of this urban corner plot tell us that Dorothea - after she inherited this huge corner house from her first husband - was "motivated by love and trust" to grant Stephan Geinperger co-ownership after their marriage. ${ }^{85}$ On the same day, in another town

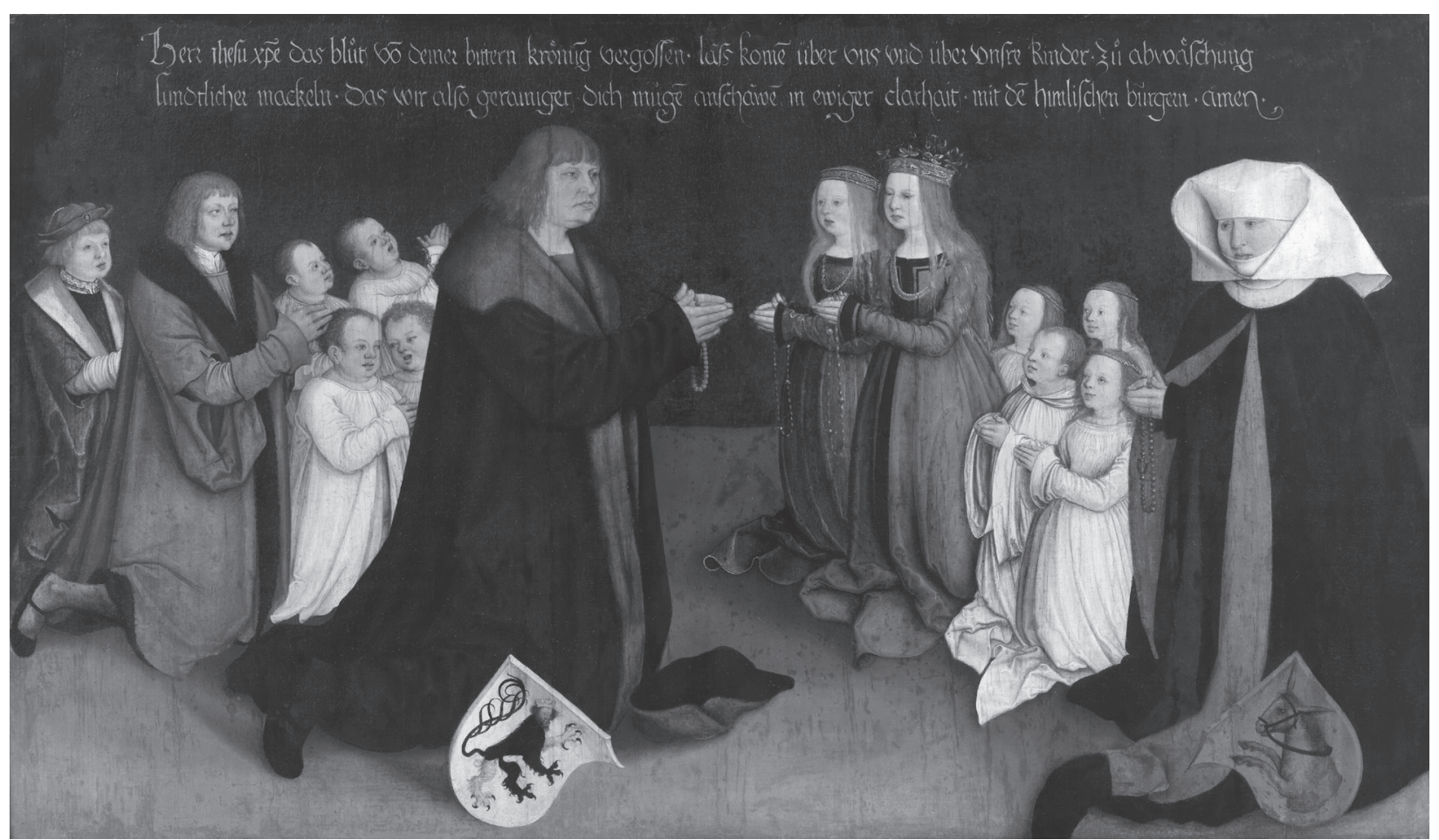

Fig. 10. The epitaph of Hans (II) Funk and Anna Gerolt, originally placed in the church of St Martin in Memmingen; Schaffhausen, MA, inv. no. A637 (photo: Schaffhausen Museum zu Allerheiligen) 
record book (the Satzbuch) it was noted that according to the former marriage contract (Heiratbrief) between the deceased husband, Hans Glockengiesser, and Dorothea, Geinperger as the new husband had to pay two hundred golden florins to the surviving children (Magdalena, Christopher and Barbara) of the deceased in order to later gain full ownership of the house. ${ }^{86}$ Consequently, the children who inherited certain vineyards according to the above-mentioned last will of the merchant Hans Werdl were the same children compensated by Stephan Geinperger, who moved into the said corner house.

Next, we will try to introduce the first husband of Dorothea Gerolt to the extent the sources allow. It seems that he was the one who laid the foundations for the wealth (properties) and reputation of Dorothea within the Wiener Neustadt urban community. Josef Mayer, in his monograph on the town, stated that the Hans Glockengiesser in question had the same grandmother as the above-mentioned Hans Werdl, but according to the sources he referred to, it must be a mistake. ${ }^{87}$ Furthermore, as it will soon be demonstrated, Glockengiesser was most probably also a newcomer to the town, like the second husband, Stephan Geinperger. Nevertheless, from the beginning of the 1470s, the given master Hans Glockengiesser appeared in the urban sources of Wiener Neustadt rather often. ${ }^{88}$ What we know about him from these sources relates to his profession and position in society and to his properties in the town. Whenever his name crops up, it is always mentioned that he was a licentiatus in canon law (geistliche recht). Concerning his landed properties, in 1471 he paid Emperor Frederick III 3000 Hungarian ducats for the right to use the tower of Peusching (today Peisching, part of Neunkirchen) during his lifetime. ${ }^{89}$ In two years' time, he bought a house in Wienergasse (27 August 1473), ${ }^{90}$ and finally in 1476 (6 February) he became the owner of that corner plot in Neunkirchnerstrasse (No. 9), ${ }^{91}$ which was later inherited by his widow and, through her, acquired by Stephan Geinperger, for whom it would have had particularly high value as he had arrived in Wiener Neustadt without any landed properties. In addition, Glockengiesser had several other pieces of immovable property in the town (Fig. 17): two houses, one behind the other, in the Frauenviertel, in the new Judengasse (1479);92 a vineyard near the village of Höflein (Hungarian: Kishöflány), next to Eisenstadt (Hungarian: Kismarton); 93 and a mill in Eggendorf (northeast of Wiener Neustadt), which in 1479 was seriously damaged in a fire. ${ }^{94}$ It is not known when he married Dorothea Gerolt, although all the above purchases were conducted alone as the entries in the town books demonstrate. Consequently, the marriage may not have taken place before 1479/1480. At the time of the wedding, he was already a member of the social and political elite; in 1468, when as a result of the council reforms of Emperor Frederick III the new town book (Ratsbuch II) was started in Wiener Neustadt, he was listed among the rather limited circle of the "Genannten". ${ }^{95}$ In 1485 he was the "Anwalt der Münze", ${ }^{96}$ and during the coming years (between 1484 and 1486), he was three times inner councillor. ${ }^{97}$ In 1488 his name was again written among the "Genannten", and next to the note, the text states that he was dead ("obiit"). ${ }^{98}$ During this period, he appeared several times as a secular witness in testaments, and it is known that he was the secular patron of the perpetual mass foundation for Frederick Sechsperger at the altar of St Andrew in the parish church of Our Lady. Later, Alexius Funk expressed his wish to be buried there, next to his brother-in-law, Hippolyt Steiner. ${ }^{99}$ In 1482 the emperor himself commissioned Hans Glockengiesser and the mayor, Wolfgang Schandl, to take care of the properties of the deceased Hans Mitterpacher (town council meeting, 23 May 1482). ${ }^{100}$ Nevertheless, Glockengiesser's social position and status should also be (re)considered in light of his origins, which are rather difficult to establish.

According to Josef Mayer, Hans Glockengiesser, as a bell founder, probably migrated from the neighbouring Unter-Eggendorf to Wiener Neustadt, where it is known that he had a mill. After immigrating to Wiener Neustadt, he made his fortune there in the second half of the 1460s. ${ }^{101}$ This argument, however, is a little vague. Moreover, the other, already discussed pieces of information point to a more "plausible" place of origin. First of all, we should consider where he did his university studies and received his degree in canon law. ${ }^{102}$ Secondly, one should also keep in mind his valuable properties with their central location in the neighbourhood of noble and courtly plots. These both suggest that he was a much more influential personality. Concerning the origins of Hans Glockengiesser, Paul-Joachim Heinig, in his monograph on the court, rule and politics of Emperor Frederick III, suggested that there was a certain Hans Glockengiesser among the proctors active in 1470/1471 in the imperial court (Kammergericht) in Wiener Neustadt. In the first two decades of his reign, Emperor Frederick had the same three procurators named in the sources, but between 1459 and 1470 at least seven new people worked for 


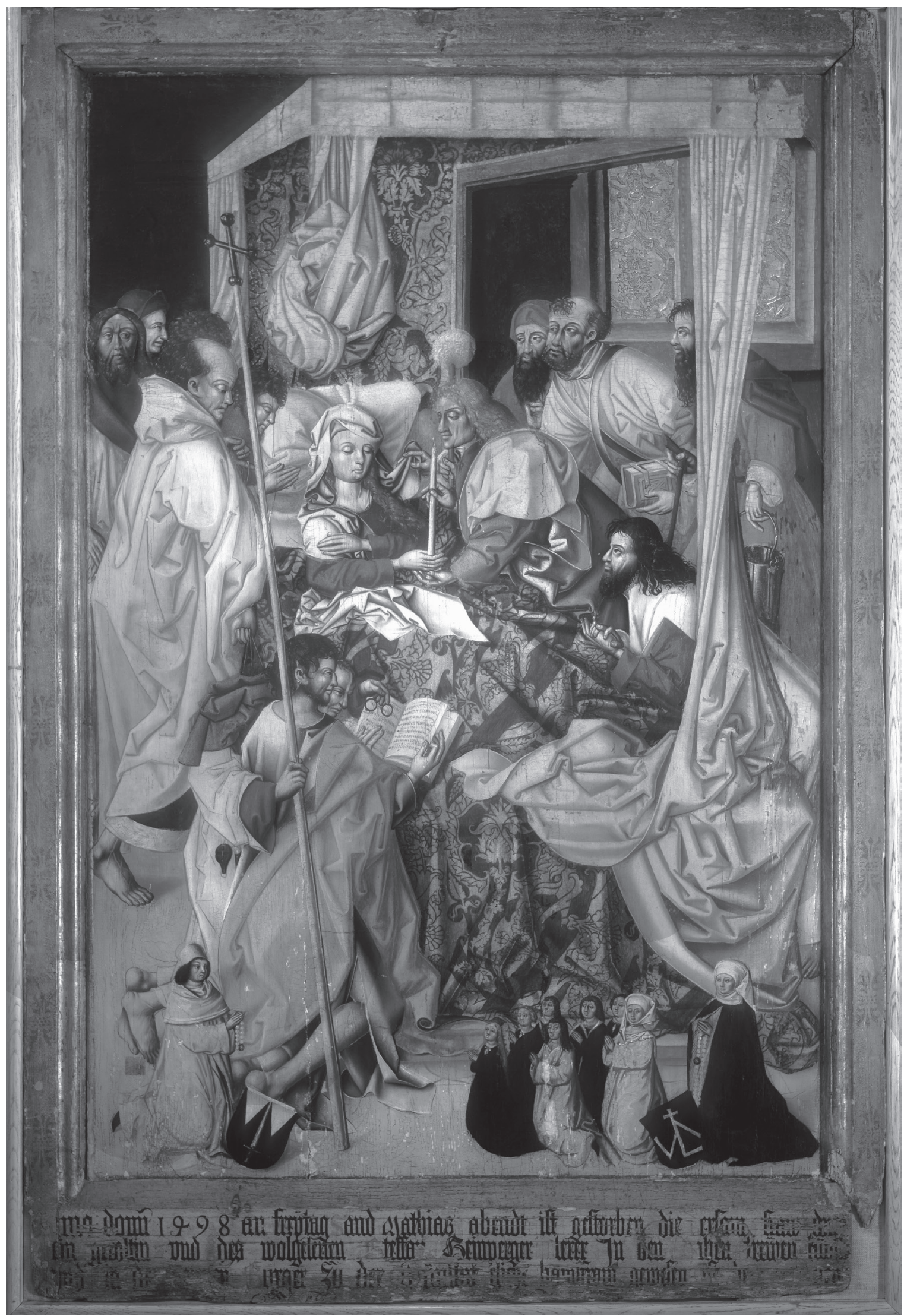

Fig. 11. Infrared reflectogram (IRR) of the Geroltin epitaph, Esztergom, KM, inv. no. 56.509 (photo: Attila Mudrák, Esztergom Christian Museum) 


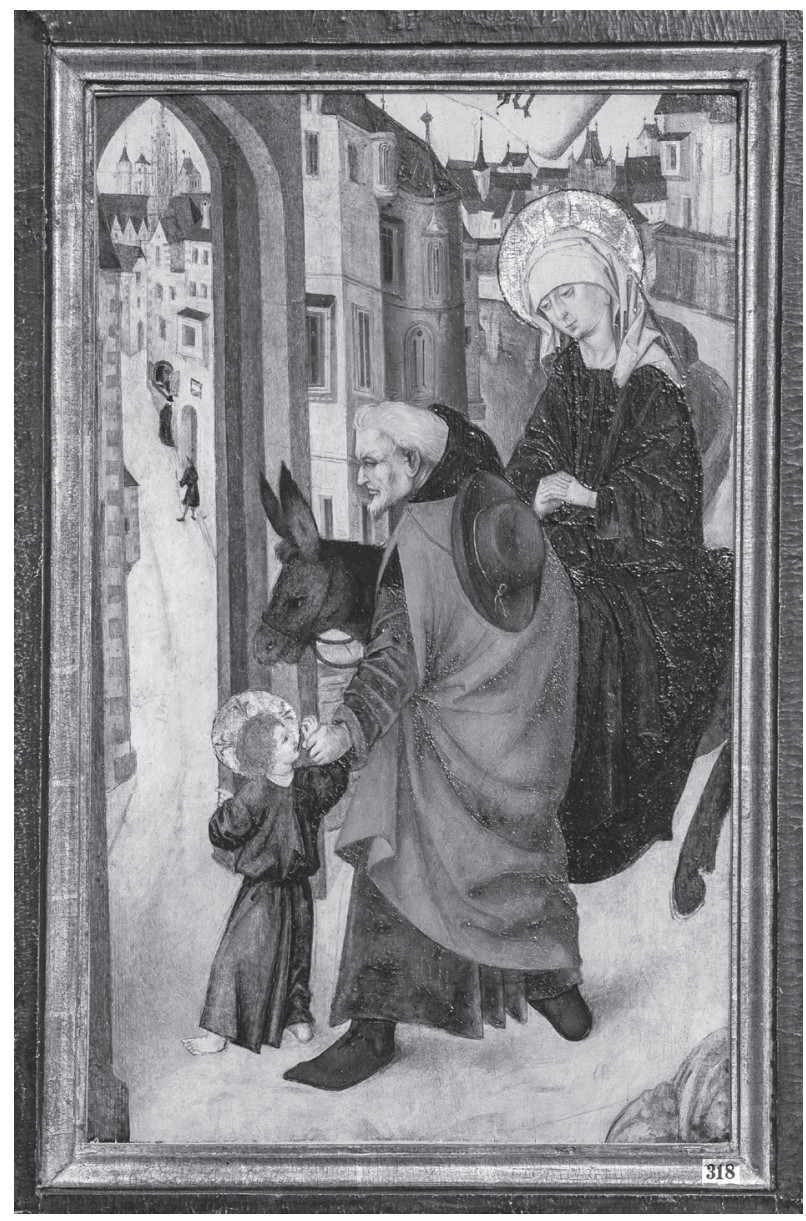

Fig. 12. The Return of the Holy Family from Egypt from the Cistercian Neukloster monastery of Wiener Neustadt; Heiligenkreuz, KSH, inv. no. 318 (photo: Stift Heiligenkreuz)

him, while around the 1470s an additional dozen were hired who were well-educated in law. A certain Hans Glockengiesser was among them. ${ }^{103}$ There is a high probability that he is the same person as the one mentioned by Josef Mayer. Even though this fact is accepted by many, there is no unanimous opinion among scholars whether he originally came from the neighbourhood of Wiener Neustadt, from Sankt Gallen, or from Nuremberg. ${ }^{104}$ Nevertheless, it seems that the university study period of the son of a Nuremberg patrician family fits well into the later data available on "our" Hans Glockengiesser in Wiener Neustadt and thus strongly supports the idea of his Nuremberg origin. The Hans Glockengiesser of Nuremberg was born sometime around 1443, as the second oldest son of the bell and brass founder, master Konrad Glockengiesser (died 1486), and his wife, Catherina Sternecker (died 1469). He did not continue the family craft and business, but instead pursued an intellectual career. He matriculated in 1459 in the university of Leipzig (newly founded in 1409), and he most likely received his degree in artes liberales there. Then he continued his studies in Padua (2 June 1464), where he received his licenciate in canon law (28 June 1465). ${ }^{105}$ The earliest found reference to the first husband of Dorothea Gerolt in Wiener Neustadt - as mentioned above is from 1468, when he was listed among the thirtyseven "Genandt"106 and was named as an "Anwalt und Prokurator" in the Kammergericht. ${ }^{107}$ In 1470/1471 he was an imperial court procurator and also that year (1471) he was granted ownership of the tower of Peusching for his lifetime by the emperor. ${ }^{108}$ From that time onwards, he invested in the immovable properties mentioned above. Another telling fact concerning his patrician ("noble") origins is that, as a member of the Corpus Christi brotherhood of Wiener Neustadt, in 1477 his name was listed among the knights (ritter) immediately after the emperor and before the confraternity master and the burgher members. ${ }^{109}$

As mentioned, the year he married Dorothea Gerolt in Wiener Neustadt cannot be established from the sources, but because all the landed properties he bought between 1471 and 1479 in Wiener Neustadt were mentioned only under his name and were not purchased by him and his wife together, we can suppose that the marriage perhaps took place around 1480. ${ }^{110}$ The data related to Wiener Neustadt suggest that he moved his residence and life from his birthplace to this town, but as was common in the region in the late Middle Ages, he must have kept his family contacts. This is very much likely, as the Glockengiessers were an influential and known family in Nuremberg. Because we have no last will, we can only speculate about his funerary bequests. Nevertheless, such a practice described below would not be an unusual or outstanding case. According to the sources related to Hans (Johannes) Glockengiesser of Nuremberg, he died in 1488 (September), ${ }^{111}$ and a funerary ceremony with the ringing of church bells was ordered for him by his kin in two parish churches in Nuremberg: in St Sebald, where his elder brother, Andreas Glockengiesser (died 1480), was buried and in St Lawrence, where his father was buried in the chancel. ${ }^{112}$ This date (the year of death) corresponds to the town record of the death of Councillor Hans Glockengiesser in Wiener Neustadt. This, along with the information we have about his above-mentioned university studies, supports the argument that the two people were actually the same. If Nuremberg was indeed his place of origin, it means he might have died in Wiener Neustadt, but it is also possible that he died while visiting his hometown and 
wished to have his funeral liturgy and ceremonies performed there. ${ }^{113}$ This could also be one additional explanation for the absence of his figure in the epitaph depicting his children with Dorothea Gerolt. ${ }^{114}$

Turning our attention back to the epitaph, the inscription there explicitly states that when it was created, Dorothea was the wife of a certain university professor, Stephan Geinperger. The relevant sources clearly show that she had remarried rather soon after the death of Hans Glockengiesser. According to the entries concerning the huge corner house and plot on Neunkirchnerstrasse (Fig. 13; Fig. 17) mentioned above, Dorothea and Stephan were already married by December 1489. As we shall see, Geinperger received his last university degree in Vienna in the spring of 1488 , the period of his studies partially corresponds to that of the Gerolt brothers. He became a member of the medical faculty during the autumn of the same year, while in the next academic year (1489/1490), he was mentioned as a professor residing in Wiener Neustadt. Consequently, he must have moved to the town before that. The question of how he became acquainted with Dorothea in Wiener Neustadt remains open. Perhaps it was through her brothers, Jakob and Bernhard Gerolt, whom Geinperger probably knew from his studies at the university in Vienna, since they were in the faculty of arts at the same time. Or perhaps, as a medicus, he was invited by the town authorities, or by his colleague Heinrich Hopf, ${ }^{115}$ who also had a business relationship with the Gerolts. It is also possible that he was attracted to the town by the presence of the court of Emperor Frederick III. Nevertheless, through his marriage he arrived both topographically and socially in the elite centre of Wiener Neustadt.

In the epitaph's inscription, he identifies himself as a learned man, a lecturer in the seven liberal arts and also in medicine. Unfortunately, the surviving university sources do not tell us when exactly Stephan Geinperger matriculated at the Viennese university, but he ("Stephanus Gainperger ex Patavia") received his bachelor of arts degree in 1472 (2 May) and his master of arts in 1476 (8 March). ${ }^{116}$ In the coming years (1477-1486), at the same time that the famous historiographer and professor of medicine Johannes Tichtel was also teaching at the university in Vienna, he held lectures with the following titles during the winter semesters: "Arithmetricam", "De anima", "Elencorum", "Algorismum", "Parva naturalia" (twice), "De sensu et sensato" (twice) and "Metheororum". In addition, he was a member of a few baccalaureate committees, first for the Saxon and then for the Rhineland "nationes". 117

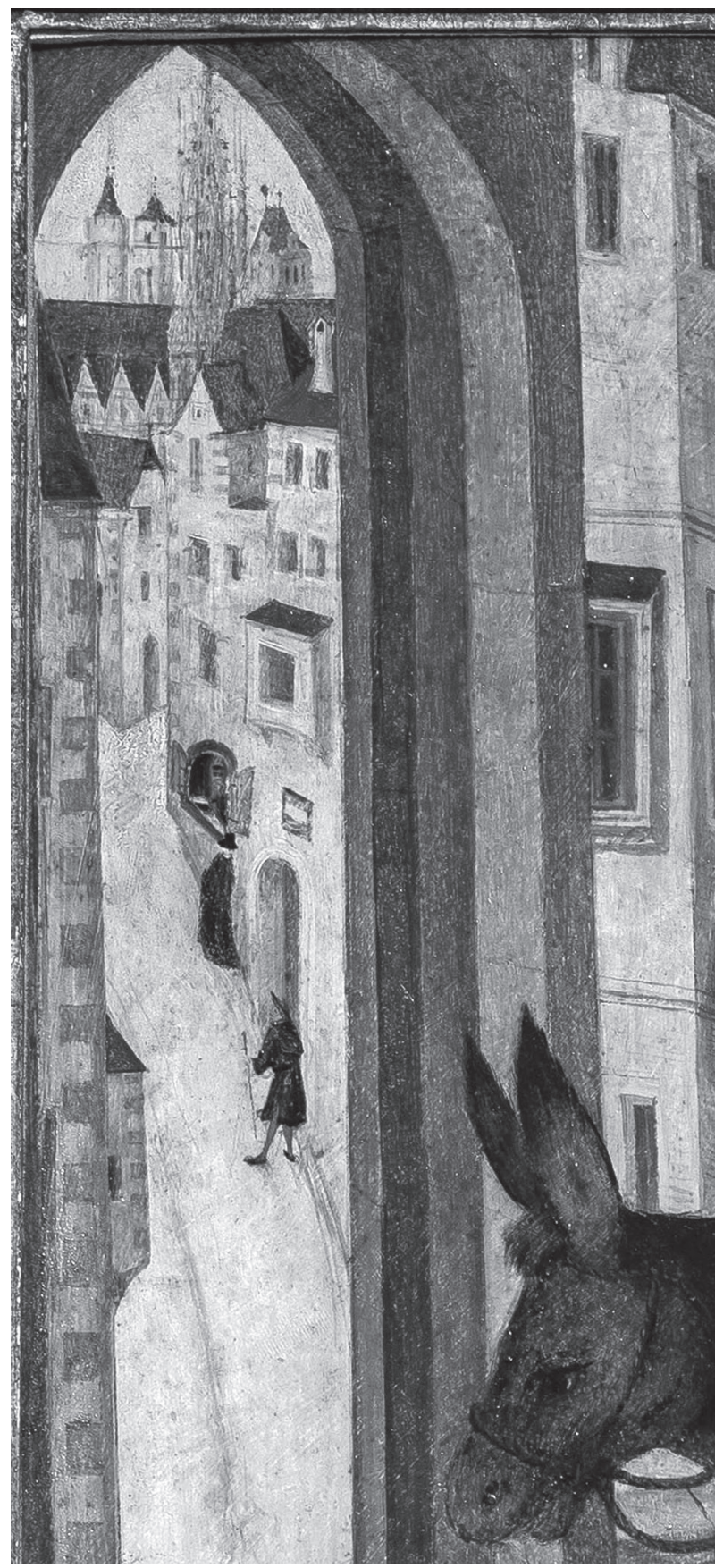

Fig. 13. A detail of the Neunkirchnerstrasse from the panel The Return of the Holy Family from Egypt, formerly in the Cistercian Neukloster monastery of Wiener Neustadt; Heiligenkreuz, KSH, inv. no. 318 (photo: Stift Heiligenkreuz)

While teaching at the faculty of arts, he also started his further studies at the faculty of medicine in 1480 , where he had his determination in 1486 and finally received his degree as a doctor medicus in the spring of 1488. In October of the same year, he was accepted as a member of the faculty. ${ }^{118}$ In 1489/1490, during the tenure of Dean Voberger, he was listed in the tenth 
position as Steffanus Geinperger ex Patavia in Novacivitate Austriae residet in the "Ärztekollegium", 119 which was the last year in which we encounter his name in the Viennese university context. ${ }^{120}$

The university sources in Vienna make it clear that Geinperger came from Passau and, since he started his studies around 1470, he must have been born around the mid-fifteenth century. Until now, in contemporary Passau, only one Geinperger had been identified in the urban source material, a certain Friedrich/Frederick Geinperg. He was mentioned in the 1440 s several times and was named as a "Salzfertiger". He also appears in the guild book of the "salcz vnd der scheflewt zech zu Pazzaw", ${ }^{121}$ inscribed in 1441 and again in 1448 among the "zechleut". 122 In another document from 1441 (27 June), Frederick Geinperger, as a burgher of Passau, was also named in relation to the "Salzfertiger zu Hallein". ${ }^{123}$ The family itself most probably originated from a smaller settlement called Geinperg, just to the south of Passau and situated along the road that led through Salzburg towards Hallein. ${ }^{124}$

During the fifteenth century, salt production in the entire region was strongly controlled and administered by salt chambers. The mining activity and cooking of the "white gold" was outsourced by princely privileges to entrepreneurs (Hallinger) who in many cases received trade rights, too. The next phase of salt transport and trade was similarly in the hands of a special group of families (Fertiger) with ducal privileges, who would first reapportion the salt that arrived in bigger barrels (Fuder) from the mining areas into smaller ones (Küfel/Kufe). Their privileges then allowed them to transport it, mainly by river. On the Danube, from Passau upstream to Regensburg or downstream to Vienna, while the other half of the salt was sent along land paths ("Goldener Steig") towards Prague, and areas beyond. The main cargoes were salt from the towns of Hallein, Berchtesgaden, Reichenhall and Traunstein. These Fertiger families (such as the Geinpergers), who also had trade privileges and were thus allowed to take part in salt trade, could accumulate rather great wealth. In Passau, those with such a privilege had formed their guild in the earlier years of the fourteenth century (1306), when the production and transportation of salt gained impetus in the context described above. ${ }^{125}$

The fragments of information uncovered about the Geinperger family suggest that Stephan Geinperger came from a middle-ranked burgher family of Passau who had accumulated their wealth from the salt trade. At that time that was the most profitable business, thus they were able to send their son to study at an univer- sity. As nothing more about the family is known and preserved, they may not have belonged to the highest economic or political elite of the town. Their name does not appear among the known councillors, judges or influential donors. Therefore, it is not completely without reason to suggest that Stefan Geinperger's coat of arms in the epitaph was not necessarily a family coat of arms brought from Passau, and it does not look like the other urban Hausmarken known from Passau. Rather, it was later granted by the duke in Vienna or when he entered another social circle in Wiener Neustadt. If this was so, it is interesting that his choice was not a symbol related to his profession (for example a book, a flask, or a serpent), but a double-edged dagger. ${ }^{126}$

Nevertheless, after his marriage to Dorothea Gerolt, the widow of Hans Glockengiesser, Stefan Geinperger very soon became a member of the council and later on held several offices in Wiener Neustadt. Already in 1491, he was inner councillor. Consequently, he must have become a member of the circle of the "Genannte" in either 1489 or 1490, since without membership he could not have been elected to the inner council, according to the above detailed new order of Emperor Frederick III. He remained in the inner council ${ }^{127}$ until 1493, when he was elected ${ }^{128}$ mayor for the first time (1493/1494). ${ }^{129}$ Before that, he had also been the town chamberlain for a year (1492). ${ }^{130} \mathrm{He}$ was reelected mayor several times: according to the available sources, first in 1499, and afterwards several years in a row between 1504 and 1507. ${ }^{131}$ For four years prior to his last period as lord mayor, he had been one of two "Gruntherren", serving as a member of the inner council in 1500 and as a "Genannter" from 1501 to 1503. ${ }^{132}$ With regard to his administrative and leading urban positions in Wiener Neustadt, it is interesting to note that in 1498, on the epitaph completed for his wife, he identified himself with his university titles and did not mention his councillorship or lord mayorship. However, as it was already noted in the case of Jakob Gerolt or Hans Glockengiesser, these highly educated people were prouder of their university degrees - these were mentioned even in the property register entries than of the temporary positions they held in the town administration. ${ }^{133}$

During his third term as lord mayor, in 1504 (26 June), he invested in a new house, buying a property in the same quarter, behind the corner house he had owned since 1489, first together with Dorothea, and later as a widower. This entire island of houses (behind Neunkirchnerstrasse) had earlier been a ducal property, which Emperor Frederick III had partially 


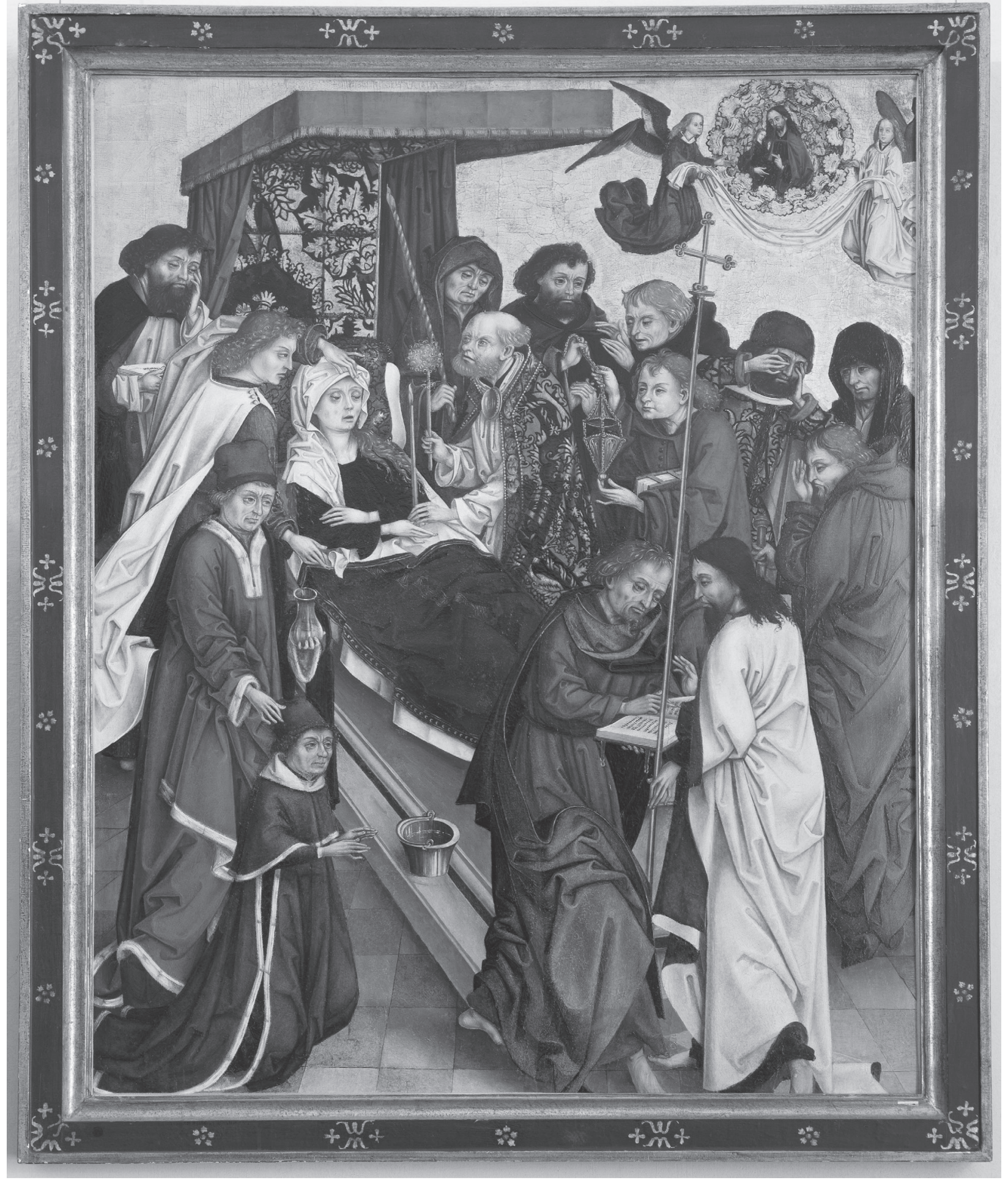

Fig. 14. The Death of the Virgin with a medicus donor from the Cistercian Neukloster monastery of Wiener Neustadt; Heiligenkreuz, KSH, inv. no. 316 (photo: Stift Heiligenkreuz)

given to the provostry. Later it became the property of the Order of St George (Kreutzherrhof), which moved its headquarter from Millstatt to Wiener Neustadt. ${ }^{134}$ Also on this island of parcels, on the farthest corner from the urban castle (Burg) was the house ${ }^{135}$ belonging to the parish priest of the church of Our
Lady of Zemendorf/Zemingdorf (a suburb - Vorort - of Wiener Neustadt). ${ }^{136}$ Thus, it was possible to reconstruct the location of this newly acquired house in the Kesslerstrasse/Hofgasse, exactly behind the corner house in which Geinperger lived (Fig. 17). ${ }^{137}$ His house must have been the site of several significant 


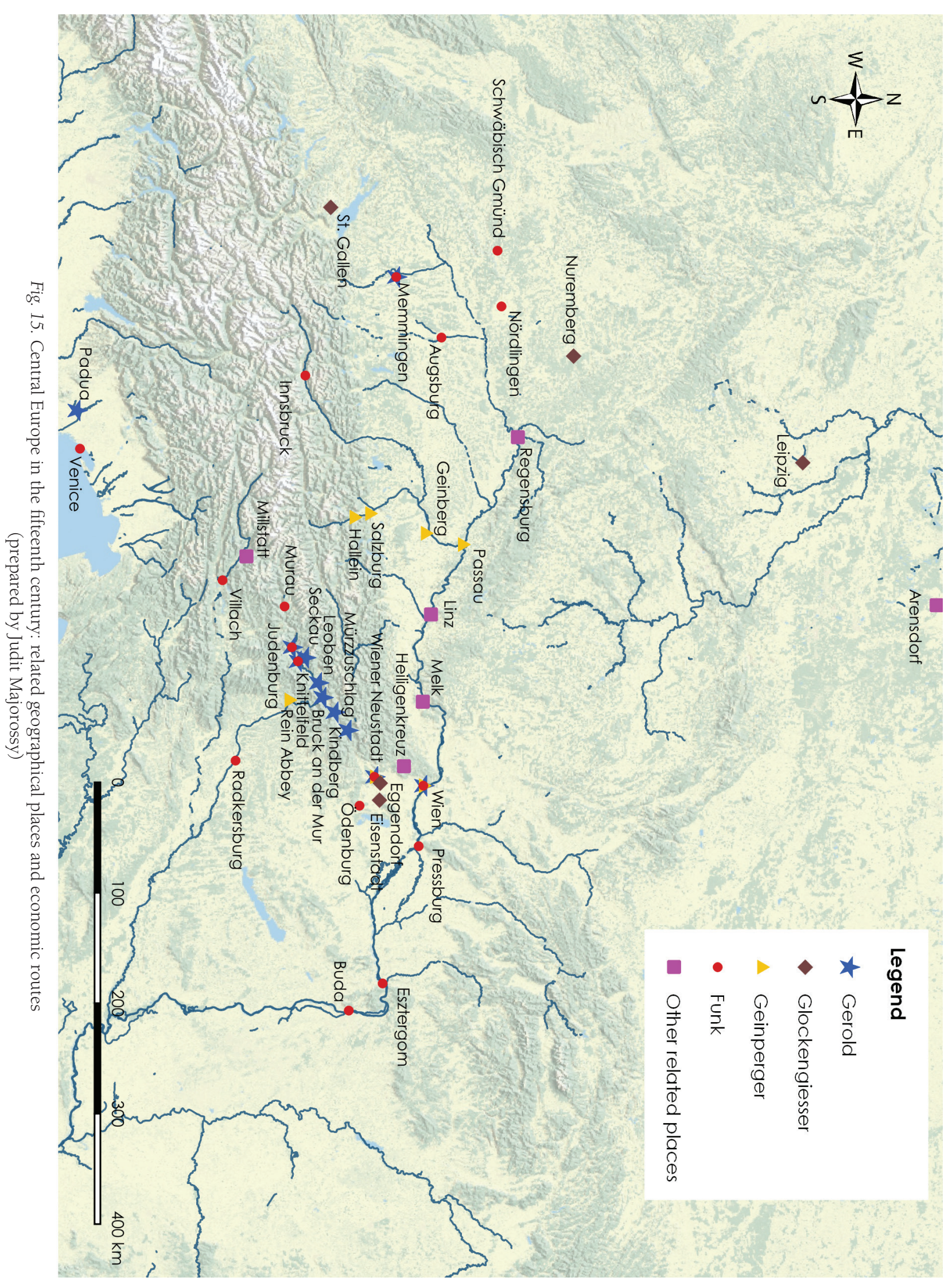




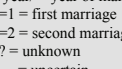

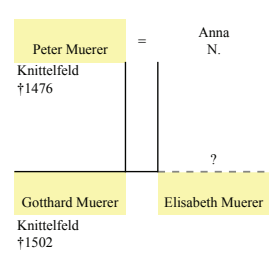

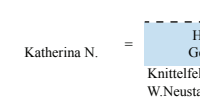

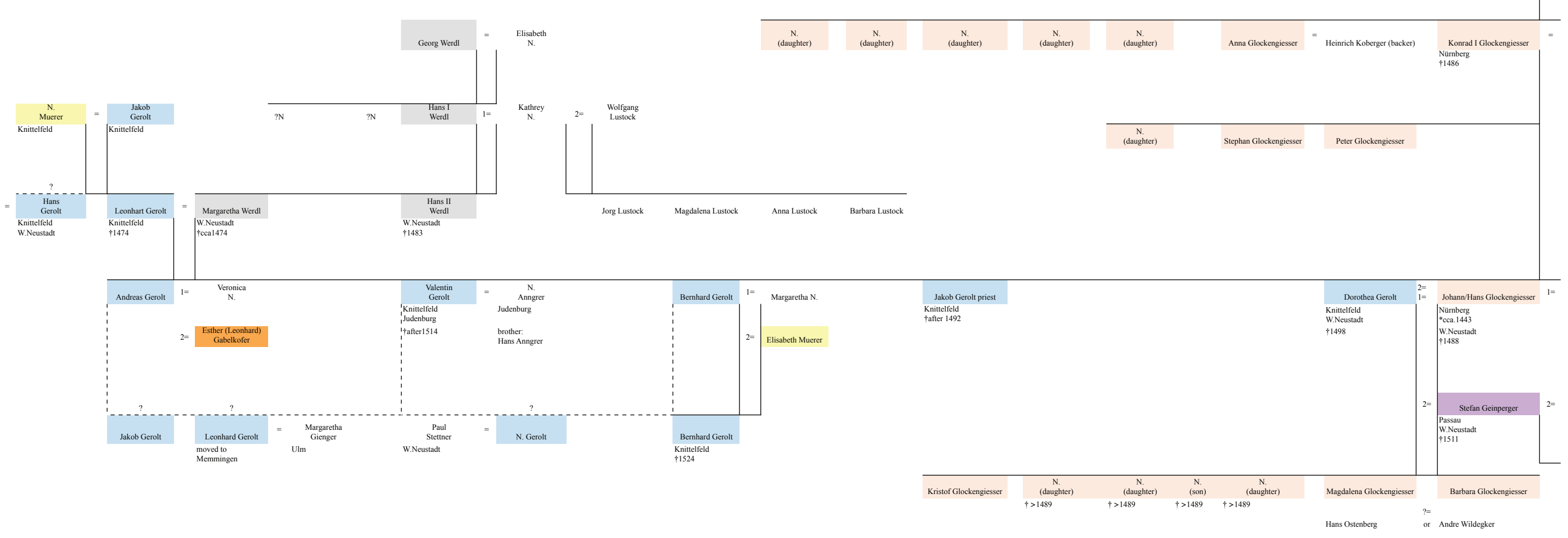

Fig. 16. The reconstructed kinship network of the Gerolt family

genealogies used: HARL 1954; PICKL 1966; EIIICH 1971; GrIEB 2007) 



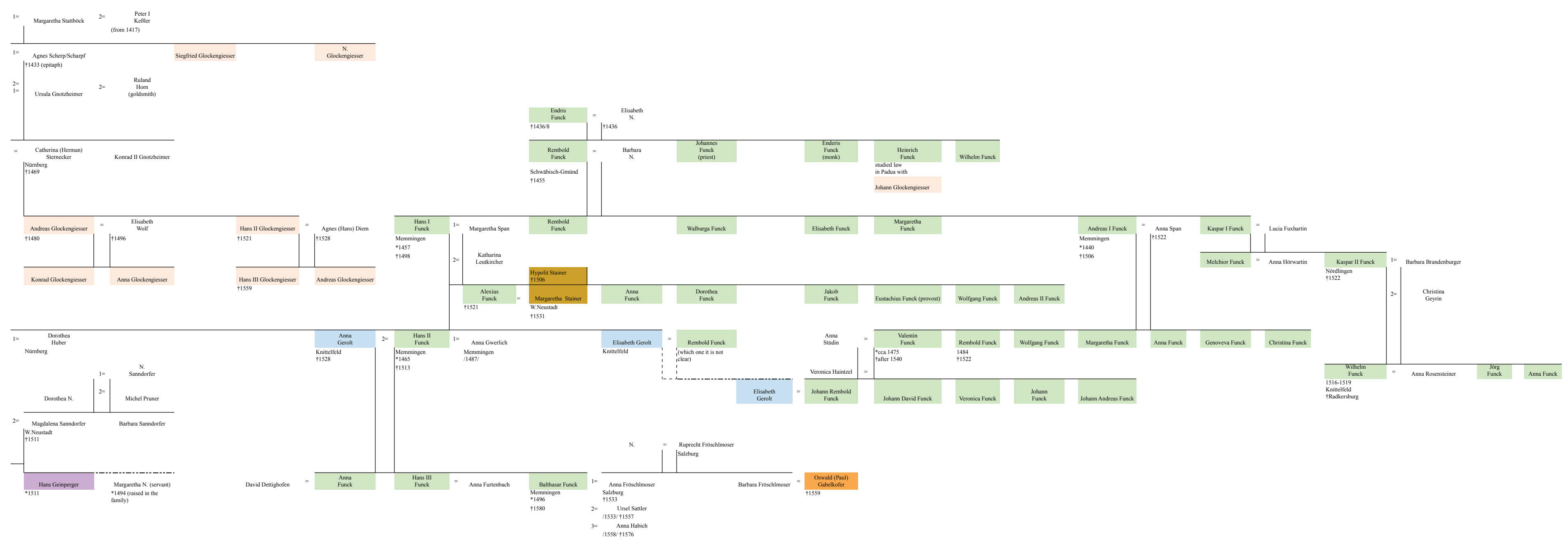





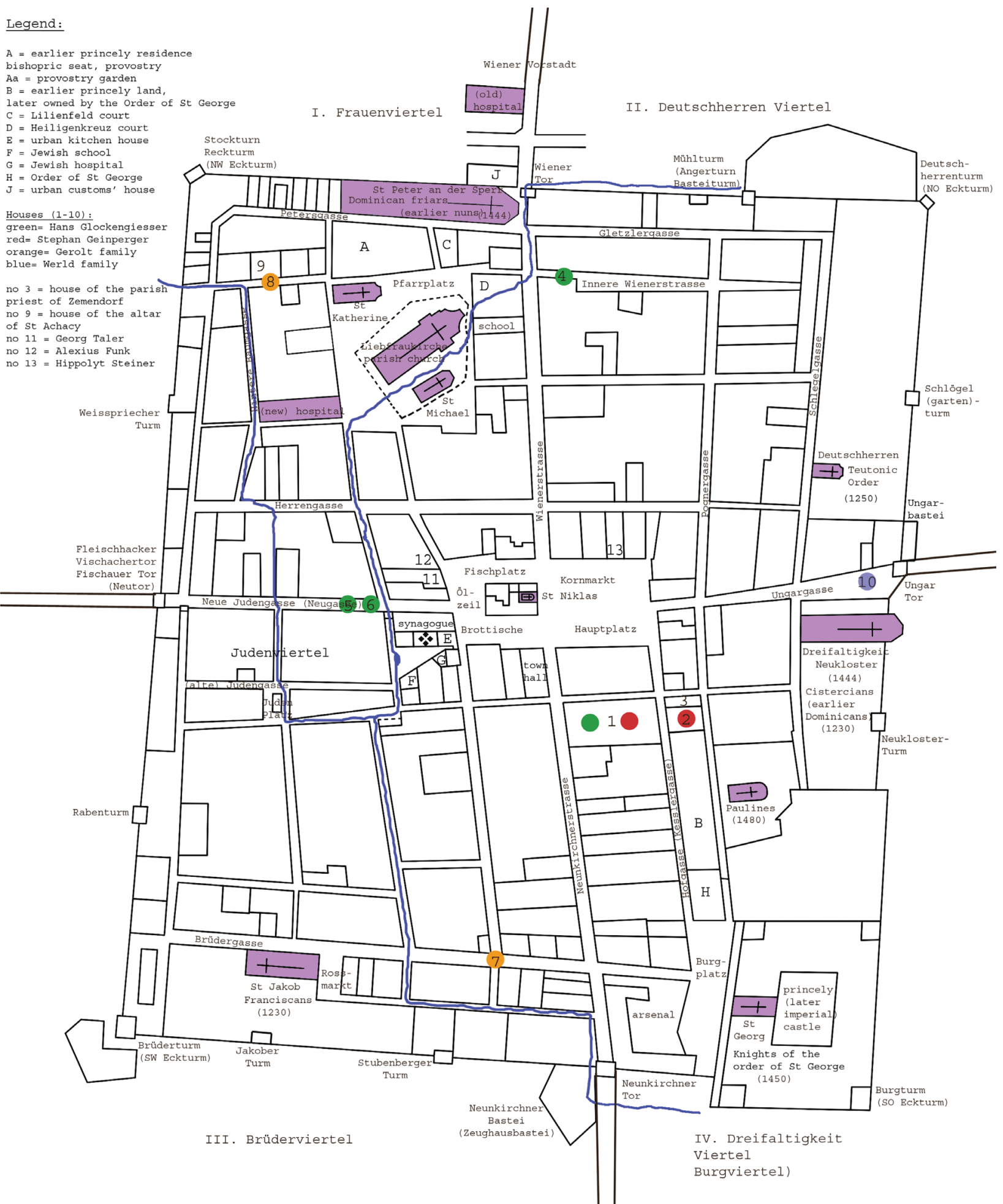

Fig. 17. The medieval town map of Wiener Neustadt, 1480-1500 with the related locations and plots indicated (reconstructed and prepared by Judit Majorossy with the help of Márton Sarkadi; maps used: Mayer 1924-1928, I/2. Tafel VII; KlaAr 1963, Tafel VI; Czeike et al (Hgg.) 1982) 


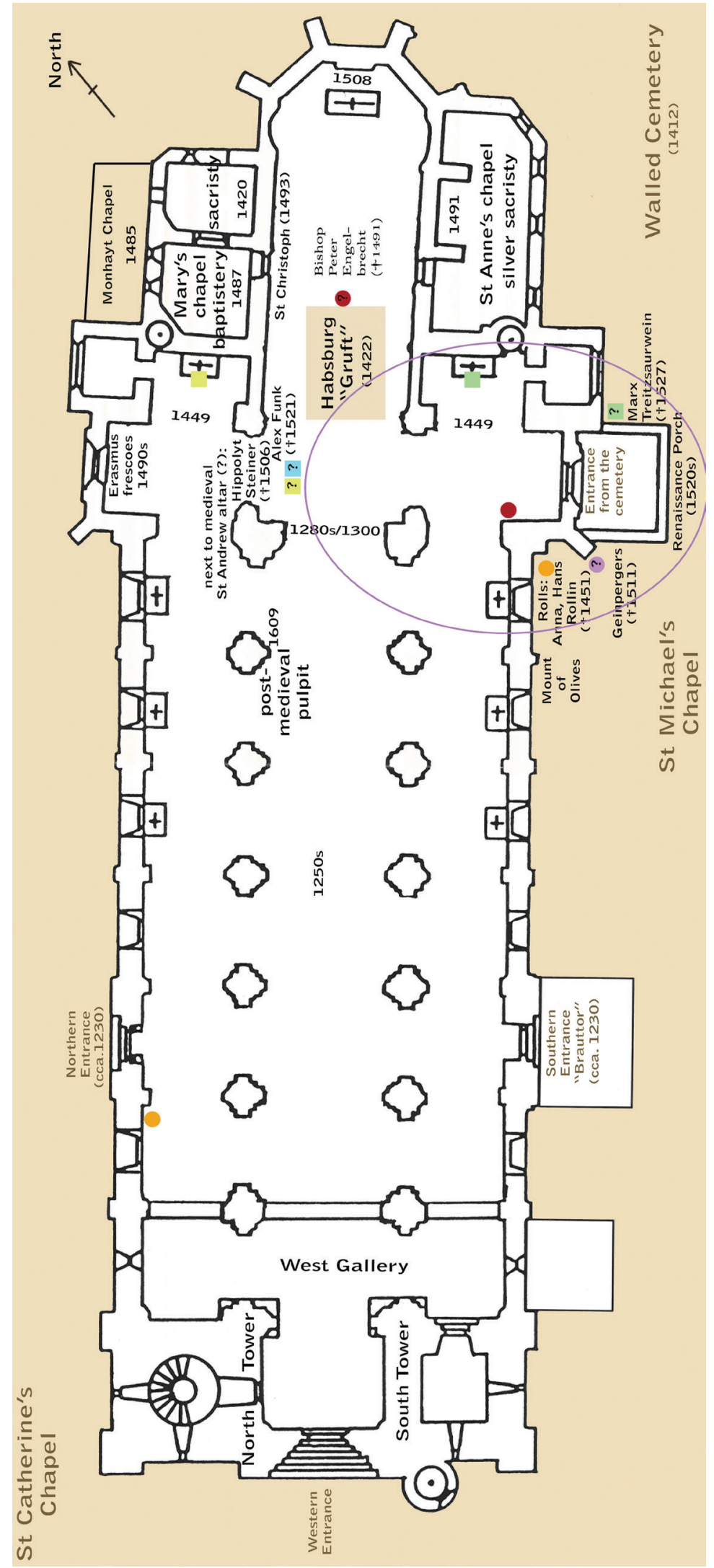

Fig. 18. The groundplan of the parish church of Our Lady (and cathedral church) of Wiener Neustadt with the suggested location of the Geroltin epitaph indicated (prepared by Judit Majorossy; based on: KoHN 1998, Appendix 3; REIDINGER 2001², 274) 
social events among which only one was documented in 1507, when as lord mayor he welcomed an illustrious company, invited on the order of Emperor Maximilian I. At this gathering, the issue of the handover of the cathedral church of Wiener Neustadt - with all its belongings - to the Order of St George was discussed as was the latter's quarrel with the Austin Canons. ${ }^{138}$

After the death of the first wife, Dorothea, in 1498 (13 May), most probably only after 1504 - since he purchased the above-mentioned second house alone - Stephan Geinperger was remarried to a certain Magdalena (born Sanndorfer). Her widowed mother - according to the extant last will of Magdalena ${ }^{139}$ was also remarried to Michel Pruner, while her sister Barbara became the wife of Hans Ottenberg. Later, the text also mentions him as Hans Ostenberger, and he was most probably a relative of the first husband of the woman from whom Geinperger bought his second house. As far as it can be established from the sources, Stefan Geinperger probably had no children with Dorothea Gerolt. The fate of the two stepchildren - according to the colour of their clothing in the epitaph - still alive at the time of Dorothea's death is not known either. What we know is that the stepdaughter was already a married woman since her head is covered in veils. However, with Magdalena Sanndorfer they had a son. The above mentioned last will of Magdalena makes it clear that in 1511 this boy - in the text referred to only as "mein lieber sun" - was still a small baby. Since his father was already dead, his legacy and the task of raising him was left to a guardian, Michel Pruner, the second husband of Magdalena's mother. He received 400 guldens "laut meins [the mother's] heyrat und gemechtbriefs" for that purpose. The name of this little boy is only known from a much later, brief entry in the property register in which Hans Geinperger, the son of Stephan Geinperger - upon becoming an adult ${ }^{140}$ - inherited the house that his father had bought in 1504. Supposing that he received the given house as part of his inheritance as an adult in 1528, he must have been born around 1510, not long before his parents' deaths. In addition, it seems that his inheritance from his parents was withheld from him for a while. By that time, the corner house on Neunkirchnerstrasse, once owned by the Geinpergers, was in other hands, which means that it was most likely sold by his guardian (some time before 1517). ${ }^{141}$ Hans did not keep the house in Kesslerstrasse for long either, since according to another entry in the same town book, he sold it a few years later (1531). ${ }^{142}$ Perhaps he moved away from Wiener Neustadt, although discovering his reason for doing this and tracing his further fate would require additional research. From his mother's last will, however, it is also clear that before his birth, the couple brought up a young girl named Margaretha or Gredl, who was mentioned as a servant in the household and was 17 years old in 1511. ${ }^{143}$

As for some pious considerations of the couple, Magdalena Geinperger's will tells us where her burial was (next to members of the Roll family) ${ }^{144}$ and what kind of donations she wished to make. ${ }^{145}$ Although no mention of her husband's wishes concerning his own burial or pious bequests. It is not known whether he ever prepared a will, if so, it was certainly lost. The only lifetime donation from Stefan Geinperger that is known - besides the creation of the epitaph - was made two years after the death of Dorothea Gerolt in 1500, and it supported the chaplain of the altar of St Elisabeth in the old hospital of the Viennese suburb (Fig. 17). ${ }^{146}$ In addition, like the first husband of Dorothea Gerolt and a few non-blood relatives (such as Hyppolit Stainer or Alexius Funk), he was among the few members of the Corpus Christi confraternity. Besides the confraternity's support, he also had an intercessor from his own family in the monastic world, a monk whom he might have supported during his lifetime. A certain Andreas Geinperger died as a mönch in the Cistercian monastery of Rein (17 December) in the last quarter of the fifteenth century. He might have been a brother (or a cousin) of Stefan and it is a telling fact that he lived in a Styrian monastery not far from Knittelfeld. ${ }^{147}$

The widow's will also helps us to reconstruct the approximate time of Stephan Geinperger's death. He must have died before 30 July 1511, when the widow Magdalena prepared her last will, purportedly in rather a hurry, since she was mentioned as being seriously ill ("der geschaffterin grausamen krankhait"), and died within a month. ${ }^{148}$ Yet, Geinperger was still mentioned as a living neighbour on a plot in Kesslerstrasse on 10 January in the same year; ${ }^{149}$ thus he must have died during the spring or early summer of 1511. In the seventeenth century his gravestone was still visible in the parish cemetery, and its carving testifies to the widow's inability to have it finished properly; the date of death was missing. ${ }^{150}$ Magdalena must have fallen ill and died soon after the passing of her husband, ${ }^{151}$ and the guardians - or the older stepsister and stepbrother - of the only child seemingly did not care about it either. Nevertheless, within the church walls, after his death, his memory was preserved for several centuries in his first wife's epitaph. 


\section{Art historical considerations}

Stephan Geinperger was already an important member of the Wiener Neustadt urban community when his first wife, Dorothea, after ten years of marriage died in 1498. The epitaph might have been ordered around this year, although - as we shall see - Dorothea Gerolt might have seen the memorial panel herself or might have even commissioned it.

The type of image fits well into the category of late medieval painted epitaphs that became widespread during the fifteenth century. The distinction between a painted epitaph and any kind of devotional/memorial painting (commissioned to commemorate votive gifts, altarpiece donations, military campaigns, various lifetime events, and so on) is sometimes hard to pin down. The exact function of such an image can usually be identified only with help of the inscription, if preserved. The structure and role of these types of images are basically the same: the painted memorials in the category to which our image belongs were not meant primarily to preserve the memory of the deceased in contrast to tomb slabs above graves. Instead their main purpose was to seek the protection of the holy patrons, to gain the advocacy of the heavenly sphere; they were a sort of guarantee for the future of the soul after death, and last but not least, were an important form of representation for the family as a whole or for those members depicted. ${ }^{152}$

The epitaph of Dorothea Gerolt belongs to a widespread type of late Gothic wooden memorial paintings that usually included three parts: an image field with the representation of saints or religious scenes, a depiction of the kneeling donor (alone or together with family members) with heraldic elements, and a third part with an inscription referring to the deceased and the date of death. This third part was usually placed on the frame of the painting. During the fifteenth century, lay donors were most often depicted in a separate field, thus marking them as earthly in contrast to the heavenly figures of the saints in the main image field. However, after 1480 it became more common for lay people to be included in the main field itself. This happened in our case as well. Still, this type of memorial does not integrate the person commemorated into the central representation, since the emphasis is still on the holy image, whose aim is to evoke feelings of piety.

The range of topics available for these votive or devotional images was wide, but there were undoubtedly a number of favourite scenes, for example, Christ on the Mount of Olives, the Virgin with Child or various depictions in relation to the Death of Christ. Among these scenes, the Dormition of the Virgin certainly had a dominant role. As an allegory of Good Death, it formed the central image of numerous epitaphs, and not only of those for women. ${ }^{153}$

Martin Schongauer's print on this theme (Fig. 2) was one of the most beloved graphic sources during the 1480s and even beyond, ${ }^{154}$ as it introduced a new compositional solution, a new way of representing the topic in contrast to the old pictorial tradition. ${ }^{155}$ An infrared reflectograph (IRR) of the Geroltin epitaph confirms what is also visible to the naked eye: the painter followed the composition of the print rather faithfully (Fig. 11). The underdrawing makes his determination obvious, to reproduce each and every detail, each fold and pleat of the original print. Yet, it is exactly this level of accuracy that reveals the discrepancy between the style and the quality of the two works; where the painting diverges from Schongauer's drawing is thereby more apparent. At the same time, because of the accuracy of the copy, it is difficult to analyse the composition and identify details such as the characteristic gestures and positions of the figures as elements of the painter's own style. His personal notes can only be detected in those few features that differentiate the painting from the etching. One of these is the underdrawing, which can be interpreted as the master's own drawing style. In contrast to the virtuosity of the print in its use of forms - especially with regard to the folds of the robes and curtains the underdrawing is quite simple, almost laconic. The lines break strongly and sharply, as if they had been drawn with a ruler. The hachures used for shading are rarely applied, and if so, they are rigid and parallel. Nevertheless, the most striking difference can be seen in the forming of the figures and faces, in the physiognomies of the people depicted and the handling of their backgrounds. Principally, it is the faces that reveal the personal style of the painter: grotesque, harsh physiognomies with deep, sometimes even forced wrinkles, large, goggle-eyes with sharp eyebrows, and fat lips characterizing the apostles. Some of their faces even appear somewhat puffed-up or swollen. The hair of the figures is modelled with dense white brush strokes, forming undulating curls. The application of the complete Schongauer composition, the golden backgrounds instead of a landscape seen through the window, which would have been more characteristic of a late fifteenth-century piece and the overall stiff style of the epitaph creates a conservative, somewhat outdated impression. Even the applied background patterns are 
known mainly from the 1460s and 1470s. The use of colours and nuances can also be considered a personal decision of the master. For the depiction of lights and shadows on the fabrics, he uses surfaces with changing nuances of rather dark and warm colours, a technique already known in paintings from South German and Austrian territories during the fifteenth century, although it only became more general in Dürer's age, at the beginning of the sixteenth century.

For a stylistic evaluation and placement of the Geroltin epitaph in its original artistic milieu, a short overview of the known paintings produced in or for Wiener Neustadt during the last quarter of the fifteenth century is necessary. The works that we know about from this period reflect the stylistic tendencies of the circle of the Viennese Master of the Scots' monastery, the Schottenmeister and the Nuremberg painting workshops strongly linked to the Schottenmeister. The painter who first comes to mind when we think of the last decades of fifteenth-century Wiener Neustadt artistic production is obviously the so-called Master of the Winkler epitaph. ${ }^{156}$ The eponymous panel painting, that is, the epitaph of Florian Winkler, ${ }^{157}$ is among those works that once decorated the parish church of Our Lady in Wiener Neustadt and are attributed to the master and his workshop. Others include the now scattered panels of the altarpiece dedicated to the Twelve Apostles (the so-called Zwölfbotenaltar), ${ }^{158}$ the prophet panels preserved to this day on the columns in the parish church of Our Lady (Liebfrauenkirche), ${ }^{159}$ and the wall painting depicting the Martyrdom of St Erasmus on the northern wall (above the entrance) of the transept. ${ }^{160}$ A closer look at these works reveals a remarkable diversity both in the elaboration of certain details and artistic quality. ${ }^{161}$ The leading master had obviously worked with a larger workshop - bringing together several painters - for quite a long time in the town. ${ }^{162}$

There is also another group of panel paintings preserved from this period which is believed to have originated in Wiener Neustadt, from its Holy Trinity (Dreifaltigkeit) Cistercian monastery, the so-called Neukloster. ${ }^{163}$ Two panels depicting the Flight to Egypt and the Return of the Holy Family from Egypt (Fig. 12-13) almost certainly belonged to the same altarpiece. A depiction of the Death of the Virgin (Fig. 14) and another one representing the Annunciation are also considered to have the same provenance. ${ }^{164}$ In the scholarly literature all these panel paintings are known as works of the followers of the Viennese Schottenmeister without any further discussion of the exact differences, although there are quite a few stylistic variations, even among details from the same panel. ${ }^{165}$

The painting depicting the Death of the Virgin (Fig. 14) is worth a more detailed analysis here. Unlike the Geroltin epitaph, this composition is not based on Martin Schongauer's print, but it does borrow various elements from the Schottenaltar's corresponding panel, which is stylistically related. The physiognomies of this Neukloster painting also indicate that several painters contributed to the piece. Most of the apostles standing in the back row have face types well known from the Schottenmeister's works. Meanwhile, the two men in the lower right corner, for example, are of lower quality and the formation of their figures overall somewhat recalls certain apostles from the Esztergom panel. Furthermore, there is another interesting detail with regard to the Geroltin epitaph, and it is the figure of the donor that appears in this Death of the Virgin panel from the Cistercian monastery of Wiener Neustadt (Neukloster). ${ }^{166} \mathrm{He}$ is shown kneeling in the lower left side, with his patron saint (Cosmas or Damian) standing behind him. Therefore, we can identify him with considerable confidence as a physician, a supposition further supported by the fact that he wears the same type of clothes (red academic cap and cloak with a white collar) as the other university professors. This brings the panel into the same exact social milieu as the one ordered by Stefan Geinperger for his wife.

During the fifteenth century, a few surgeons (barbers and Wundärzte) are known from Wiener Neustadt, but only three were formally educated physicians (Buchärzte) with degrees in medicine (as the sources say: "Lizentiat in der Arznei"), and consequently could be portrayed in the above-mentioned red clothes. ${ }^{167}$ Heinrich Hopf appeared in the sources in the 1460s, bought a house on the Main Square not far from the Glockengiesser-Gerolt couple at that time. According to his will, he died at 1491. His widow, Anna, the daughter of Hans Weinberger was remarried to another physician, Georg Taler, who like Geinperger was "meister der freien Künste und der Artznei Lehrer". ${ }^{168}$ After completing his studies in Vienna, he also taught in the faculty of arts at the time when Geinperger was pursuing his own studies. In 1489/1490 they were both members of the faculty of medicine at the university in Vienna; Taler this time resided in Melk, and Geinperger was already in Wiener Neustadt. ${ }^{169}$ Finally, as a married man, Georg Taler also moved to Wiener Neustadt, where, like Geinperger, he became mayor a few years later, in $1500 .{ }^{170}$ 
Were the two couples in close contact with each other? Geinperger was certainly in contact with Taler at the university first as a student, and later as a colleague at the faculty of medicine. Thus, they most probably kept in touch in Wiener Neustadt, too, where they sat on the same town council. Whether Geinperger, after his arrival to the town, developed a closer friendship with Hopf cannot be established from the sources, although his testament indicates that Hopf had a credit relationship with the Gerolts. ${ }^{171}$ The question naturally arises; could this panel (from the Neukloster), commissioned by a colleague from the town somewhat earlier, have served as a kind of example for Geinperger? This remains, however, an open question for the time being. Because its original framing and perhaps also its inscription were lost, it is not even clear whether this panel painting from the Cistercian monastery served as an epitaph for the physician depicted, in this case probably Heinrich Hopf. ${ }^{172}$ Or, it was another type of devotional image, in this case the figure might also be Georg Taler. Furthermore, it is also uncertain whether it was originally placed in the Neukloster or was only later taken there, during the "Baroque cleaning" of the parish church of Our Lady, or bought perhaps elsewhere and reached the Neukloster with the above-mentioned collection. ${ }^{173} \mathrm{Nev}-$ ertheless, the work reveals that the topic of the Virgin Mary's death was a fairly fashionable choice for memorial panels in Wiener Neustadt as well, if we consider not only the Geroltin epitaph but the somewhat later Funk epitaph, too. ${ }^{174}$ This brief overview of the artistic milieu of Wiener Neustadt - the context in which all the above-discussed artworks were made - allows us to conclude that the painter of the Geroltin epitaph does not fit well into this stylistic environment. Several differences can immediately be discerned. However, there are a few general elements that do point to the stylistic circle described above. Previous literature on the works of the Master of the Winkler epitaph mentions a sharp drawing style as well as a sharp rendering of ugly, caricature-like faces with heavy eyelids as specificities of the workshop. Such basic features all turn up in our epitaph as well, yet the general effect is different, the faces are plumper, more bloated. The quality is certainly lower and the entire work strikes us as a mere aftertaste of the Master of the Winkler epitaph's style.

A more objective connection to the circle of the Schottenmeister is indicated by the motif of the applied brocade patterns. ${ }^{175}$ The muster of the bedspread turns up in various paintings from this stylistic milieu: in the
Schottenaltar itself in various scenes and, for example, on the throne of King Chlothar in a panel preserved in the Hungarian National Gallery. This latter work illustrates a scene from the legend of St Eligius and is attributed to the same workshop. ${ }^{176}$ At the same time, our epitaph and its various details (especially the Virgin's face) overall evoke the Nuremberg-Bamberg works of art of the 1470s and 1480s; art from the painting environment in which the Schottenmeister and the Master of the Winkler epitaph were schooled, such as the works of Hans Pleydenwurff and Wolfgang Katzheimer. In general, the Geroltin epitaph points to a low skilled painter who had not received his training in the circles of the Master of the Schottenaltar or the Master of the Winkler epitaph, but came from abroad and could have begun the work at a later time in the Wiener Neustadt workshop.

\section{The location of the epitaph}

According to historical evidence, the church of Our Lady (Liebfrauenkirche), as the main parish church of the town and cathedral of the bishopric (which functioned between 1469 and 1785), served as a chosen burial place for the most important burghers of Wiener Neustadt. ${ }^{177}$ In her book on the historical inscriptions collected for the town, Renate Kohn has already discussed the Geroltin epitaph as obviously originating from the parish church of Wiener Neustadt, ${ }^{178}$ basing her opinion - as well as the transcription of the inscription - on a seventeenth-century codex (Codex 9221) preserved in the Austrian National Library. ${ }^{179}$ Recently this manuscript has been thoroughly analysed and identified as a collection of inscriptions compiled by the genealogist and historian Valentin Preuenhueber (died 1642) with certain parts possibly recorded by others at his request, and accordingly it can be dated approximately to $1630 .{ }^{180}$ It is striking and may be of importance from our perspective that the collection does not mention inscriptions on painted epitaphs, ${ }^{181}$ although we know of at least two - in addition to the Geroltin memorial - that must have been in the church at that time, namely the epitaphs of Florian Winkler and Alexius Funk. ${ }^{182}$ Preuenhueber's failure to pay any attention or attribute importance to these perhaps reflects his view that it was only grave slab inscriptions - documenting the time of death and burial place of people - as written sources. Only these were of interest to him, while painted epitaphs were excluded of the collection. However, it is also possible 
that these painted wooden memorials were no longer in the church at the time of his activity. In any case, the inclusion in the collection of the death inscription relating to Dorothea Gerolt suggests that her grave, at least, must have still been visible in the church. ${ }^{183}$ It is also quite possible, that the late Gothic painted memorials in the church interior were removed to make space for Baroque ones. ${ }^{184}$ We know that a number of interventions were carried out in the inner space of the late medieval church around the year 1628 and also that a large number of epitaphs and various other pieces of new liturgical furnishing were made and placed in the church in the early years of the seventeenth century. ${ }^{185}$ Consequently, it is worthwhile to consider how and where Valentin Preuenhueber himself, or the person charged to collect the inscriptions for him saw the text related to Dorothea Gerolt and the inscription cited from the gravestone of her second husband, Stefan Geinperger. ${ }^{186}$ Did the copyist see only the tombstone or both the slab and the epitaph?

Another significant piece of information that could be - at least indirectly - deduced from Codex 9221 is the approximate location of the memorial (be it the gravestone or the epitaph) within the church itself. The whole structure of the collection of inscriptions - at least with regard to the church of Our Lady in Wiener Neustadt - suggests that the collector documented the texts in a certain topographical order, beginning with the Habsburg memorial (Habsburg Gruft) in the chancel erected by Ernst the Iron for his children and for himself. ${ }^{187}$ (Ernst der Eiserne was the father of Emperor Frederick III, who claimed for a while to be the head of the Leopoldian line of the Habsburg family.) The next inscription, following the long description of the Habsburg memorial is from the gravestone of Petrus Engelprecht, first bishop of Wiener Neustadt (1476-1491). According to the later literature, that gravestone must have been somewhere in the sanctuary (in the vicinity of the Gruft, either behind or in front of it) by the main altar, and was later moved to the location where it is still visible today. ${ }^{188}$ The third inscription is from the memorial dedicated to Dorothea Gerolt. Thus, we can posit that the epitaph/grave must have been placed in a fairly prominent place in the newly enlarged cathedral church, in the immediate neighbourhood of the sanctuary, most probably in the transept (Fig. 18). Assuming the gravestone of the first bishop was moved only a short distance from its original late medieval place in the sanctuary to its present-day location in the transept wall, the Geroltin grave/epitaph could have been somewhere around the transept crossing. That would place it near the first main composite columns of the southern aisle. At the same time, it is also possible to picture it rather close to the southern entrance of the church, which leads to the cemetery. ${ }^{189}$ An additional consideration should also be mentioned: if the location of the epitaph was chosen by the deceased Dorothea Gerolt herself, we should recall the already detailed family tradition from her hometown parish church of Knittelfeld. There, the parents were buried by the column standing opposite the pulpit, where the altar founded by their family was also located.

Unfortunately, the hasty archaeological excavations done in 1977/1978 only noted the almost complete absence of the late-fifteenth or early-sixteenth-century graves among the findings. Moreover, only a few contemporary (early sixteenth-century) gravestones were identified in secondary usage. For example, as steps to the Baroque altars in the side chapels by the sanctuary. ${ }^{190}$ During the construction of the new Baroque floor, this level might have been cleared away. In addition, it was also mentioned in the archaeological report that around the post-medieval pulpit (constructed in 1609), no elements of an earlier (late Gothic) structure were found; therefore, it is still not known exactly where the medieval pulpit might have been.

Nevertheless, the presumably prominent location of the Geroltin grave and/or epitaph ${ }^{191}$ could be explained by the obviously special social position occupied by Hans Glockengiesser and his family in the life of Wiener Neustadt. Thus, it is also plausible that his burial place might have been somewhere in the transept, ${ }^{192}$ as was the resting place of Hippolyt Steiner and the nearby epitaph of Alexius Funk. The practice of burying a remarried widow next to her first husband was not unusual; numerous examples are known. There could have been a variety of reasons for this decision, either simple practical ones or more complex ones concerning personal interests in modes of representation, as a first marriage was socially of greater importance. ${ }^{193}$ A prominent place of burial was clearly Dorothea Gerolt's due given not only her own family background but also the fame and social position of her first husband. Moreover, it was not yet clear where Stefan Geinperger (the second husband) would be able to have his burial place. ${ }^{194}$ Consequently, the ordering and placement of an epitaph for Dorothea in a highly prominent place inside the church must have presented a perfect opportunity for him to promote his own reputation.

We do not know of any written regulations or documented decisions by the town or the church on 
who was allowed to be buried inside the church of Our Lady, or if there were any conventions concerning which church was used by which social class for burial. ${ }^{195}$ However, some kind of unwritten norm or practice must have existed. Geinperger - as a newcomer with no influential lineage in the town - might have used his wife's epitaph as a chance to preserve his own memory within the church, in a most prominent place.

\section{Conclusion}

The overall analysis of the epitaph in all its details reflects Geinperger's intentions and opportunities. The panel has large dimensions and conforms to other preserved epitaphs from the town, ${ }^{196}$ although its artistic quality remains well behind the general standards of the other known Wiener Neustadt panel paintings. Even with these dimensions, a painted, wooden epitaph would probably not have required serious financial sacrifice by the donor, given that even the best quality painted epitaphs of the period cost around 20-25 guldens. ${ }^{197}$

A survey of late medieval female memorials - an outstanding number of which were preserved in Nuremberg - in general clearly reveals that just as in life, so too in death were women almost inconceivable without their husband(s). The husband is usually represented on the heraldic right-hand side, thus in the more important position, in memorials to the wife. Children in most of the cases were also depicted, partially as attributes of the marriage itself, and their usual arrangement was gender based. During the late fifteenth century, these epitaphs thus became a common form of family memorials. ${ }^{198}$ Previous husbands were considered as belonging to the history of the family, to the "life history" of the deceased woman. Given this way of thinking, it is thus understandable why female epitaphs often contained representations of both husbands. ${ }^{199}$ Including the spouse from a previous marriage was not a Nuremberg speciality; this custom can be observed in various epitaphs from other geographical regions. ${ }^{200}$ In this respect, it is remarkable that Stephan Geinperger omitted a representation of Hans Glockengiesser from the epitaph commissioned for Dorothea, placing only himself in the position of husband of a "Gerolt daughter". Unfortunately, we have no information on the last will of Dorothea regarding this matter, nor on the wishes of the children from her first marriage to Hans Glockengiesser, although they were still alive at the time the epitaph was commissioned. There are such examples of stepchildren urging that a depiction of their father be included in the image, but this does not seem to be the case with this epitaph. ${ }^{201}$

Given the rather old-fashioned style of the painting analysed above, it is extremely tempting to consider an earlier date than the one suggested by the inscription beneath the image. Experience shows that generally one has to be cautious when dating an epitaph based on its inscription. The inscription only records the date of death, but the epitaph was often ordered some time later, ${ }^{202}$ or conversely, during the life of the deceased. ${ }^{203}$ However, neither of these could be considered a general rule. Moreover, there are known examples when the epitaph was later updated, documenting changes in the family, ${ }^{204}$ and it was quite a general practice that those who died after the memorial was completed are later indicated as such on the painting. ${ }^{205}$ However, in our case there is no sign of any later intervention; not even the infrared reflectography (Fig. 11) has pointed in this direction. ${ }^{206}$

Naturally, the identification of the blazon is crucial in order to be sure that the painting was not ordered at an earlier point with only the inscription added by the second husband. Unfortunately, the depicted coat of arms has not been found in any other place in Wiener Neustadt (or in Passau) nor in the written source material so far. However, the coat of arms of the Glockengiesser family is clearly known for the Nuremberg branch of the family. ${ }^{207}$ This could mean that probably the painted blazon really belongs to the second husband. In addition, there are other telling facts that offer strong support for the identification of Stephan Geinperger in the image, even without proving indisputably who the owner of the coat of arms was. First, the figure's robe, as discussed above, was typical for a physician having studied at the university in Vienna; this detail thus corresponds perfectly to the titles listed in the inscription. Second, the position of all the children on one side also corresponds to the information known about Geinperger. In contrast to the general practice of grouping descendants according to gender, namely the boys with the father and the girls with the mother, in this case all are gathered around the mother. This suggests that they are Dorothea's descendants, and none of them is related by blood to the man depicted. Consequently, they must have been the children from the first marriage. ${ }^{208}$

It cannot be completely excluded though, that the painting was commissioned by Dorothea Gerolt herself and even begun during her lifetime, which would 
explain to a certain extent the somewhat outdated character of the painting. Even if, it must have been completed only after her death, with the painting of at least some figures of the family and the addition of the inscription. Questions such as who had the initial idea for the epitaph, who determined the iconographic programme, what Dorothea herself thought about this, and what the intentions, opinions and wishes of the surviving two Glockengiesser children - Christopher and either Magdalene or Barbara - were remain open for the time being. Nevertheless, the final version of the painting and the ideas transmitted by the image and text surely complied with the concept and intentions of Stephan Geinperger. A son of a Salzfertiger from Passau, he was proud of his own achievements at the university in Vienna, as his garment and his own titles on the epitaph show. At the same time, he might have been a kind of newcomer in Wiener Neustadt and did not necessarily belong to the old regional Geschlecht community or Nuremberg patrician circles. Therefore, the given memorial, placed in a prominent location inside the urban parish church of Our Lady - which was already at that time the episcopal cathedral church - must have been a perfect opportunity to strengthen his own social position. The intention of emphasizing himself - as opposed to his wife, for whom the epitaph was made - is striking not only in the formulation of the inscription but also in the appearance of his blazon twice in the painting, at his feet and in the upper left corner of the room.

The above analysis, at first glance, reveals an individual family history, a case study of the late fifteenth century. However, it also sheds light on more general issues, such as the evidently frequent occurrence and presence of step and patchwork families in late medieval civic society, ${ }^{209}$ the kinship and networking strategies of the economic and political elites as well as the newly emerging intellectual elite within these circles, and as a consequence the growing popularity of university studies and its increased importance within these urban elite circles. It is because of our unconventional approach that such a variety of conclusions can be drawn from our analysis of a single "family portrait". Instead of examining the subject from the usual male angle, we did so from the female one. Moreover, we took as our starting point not the above-discussed social phenomena themselves but rather a single artwork, the epitaph.

All this proves that the interpretation of a painting needs and deserves more than just a stylistic, iconographic analysis, which is the norm in art historical research. What should be employed instead is a complex set of various methods (several including diverse, non-destructive investigations, methods borrowed from the natural sciences) and historical approaches. Nevertheless, this has also shown that a piece of art that is of lesser artistic quality can, in certain cases, provide us with much more information on the everyday (religious, social, economic and political) life of contemporary people than one of superior quality that relates to a rather narrow social milieu of royal courts or the highest social circles.

Finally, the analysis and research presented here hopefully demonstrate that such a pictorial object can also serve as an additional source, complementing written historical documents. Its fortunate survival and the proper identification of the figures depicted are what prompted us to investigate and allowed us to uncover a smaller and wider regional kinship network that otherwise might have remained hidden.

\title{
ABBREVIATIONS \\ Archives, manuscripts
}

\author{
ÖNB, HS-AltD \\ Cod. 9221 \\ ÖStA, HHStA \\ AUR \\ PStA \\ II.A. 25 \\ II.A. 15 \\ III.6 \\ StLA \\ AUR \\ A. Knittelfeld Stadt \\ Österreichische Nationalbibliothek, Sammlung von Handschriften und alten Drucken, Vienna \\ Inscriptiones variae sepulcrales (Unbekannt). [ohne Jahresangabe]. Vorwiegend Grabinschriften \\ in Oberösterreich (Historia: Archeologia) \\ Österreichisches Staatsarchiv, Haus-, Hof-, und Staatsarchiv, Vienna \\ Urkunden (Wiener Neustadt) \\ Stadtarchiv Passau, Passau \\ Zechenbuch der Salzfertiger und Schiffleutzeche, 1422-1576 \\ Beschau der Stadtmauer, um 1400 \\ Gemainer Stat Passaw Recht und Freyhaiten sambt allten und neuen verträgen, mit Handwerks- \\ ordnungen, 1258-1539 \\ Steiermärkisches Landesarchiv, Graz \\ Urkunden (Knittelfeld) \\ Archivalien - Stadt Knittelfeld
}




\author{
K. 77 . H. 341 \\ K. 77 . H. 342 \\ K. 77. H. 349 \\ K. 77 . H. 350 \\ K. 77 . H. 351 \\ K. 82 . H. 382 \\ K. 82 . H. 383 \\ K. 84. H. 406 \\ A. Judenburg Stadt \\ K. 321. H. 669 \\ UBG \\ MS 74 \\ WNStA \\ Ratsbuch II \\ Gewährbuch I \\ Satzbuch A \\ Schrin CXIX, Nr. 45.
}

Die Auswirkungen der Reformation und Gegenreformation in Knittelfeld und dem übrigen Bereiche des Stiftes Seckau, von dr. Paul DeDIC 1943

Verzeichnis der Geistlichkeit in Knittelfeld, 1231/1674, zusammengestellt von Lois HAMmER 1951

Urbar, 1483

Urbar, 1489

Urbar, 1490

Urkunden - Gerolsche Stiftung

Urkunden - Muerersche Stiftung

Gottsleichnamsbruderschaft, 1478-1662

Archivalien - Stadt Judenburg

Kirchenrechnungen, 1504-1514

Univeritätsbibliothek, Graz

Missale, vor 1477 (Alte Sign. 37/18)

Archiv der Stadt Wiener Neustadt, Wiener Neustadt

Ratsbuch II (Band 8), 1467-1525

Gewährbuch I (Band 573), 1430-(1465)-1555

Satzbuch A, 1456-1645 (Sätze 1456-1591; Geweren 1453-1464)

Gottsleichnamsbruderschaft, 1460-(1477)-1607

\section{Published sources}

UAW

AFA III/1

AFA III/2

AFM II

AFM III

Matrikel Wien

$\mathrm{UPa}$

AGA I/1-3

AGA II/1

AGA II/2

AGA II/3-6

Universitätsarchiv der Universität Wien, Vienna

Bracher, Andreas - Maisel, Thomas - MatschinegG, Ingrid (Hgg.): „Wiener Artistenregister“ 1447 bis 1471. Acta Facultatis Artium III (UAW Cod. Ph 8), Teil 1: 1447 bis 1471, Wien: Universität Wien, 2007

Bracher, Andreas - Maisel, Thomas - Matschinegg, Ingrid (Hgg.): „Wiener Artistenregister“ 1471 bis 1497 . Acta Facultatis Artium III (UAW Cod. Ph 8), Teil 2: 1471 bis 1497, Wien: Universität Wien, 2007.

SChrauf, Karl (Hg.): Acta Facultatis Medicae Universitatis Vindobonensis. Band II: 1436-1501. (UAW Cod. Med 1.2 AFM 1436-1501), Wien: Verlag des Medicinischen Doktorencollegiums, 1899

SCHRAUF, Karl (Hg.): Acta Facultatis Medicae Universitatis Vindobonensis. III: 1490-1558. (UAW Cod. Med 1.3 AFM 1490-1558), Wien: Verlag des Medicinischen Doktorencollegiums, 1904. SOukup, Kurt - Szaivert, Willy - Gall, Franz - PaulHart, Hermine - Szaivert, Marta - et al: Die Matrikel der Universität Wien (1377-1659) (Publikationen des Instituts für Österreichische Geschichtsforschung, 6. Reihe: Quellen zur Geschichte der Universität Wien, 1. Abt.), GrazWien-Köln, 1956-1993.

Universitá di Padova, Padua

ZontA, Gasparo - Brotto, Giovanni (eds.): Acta Graduum Academicorum Gymnasii Patavini. I/1-3: Ab anno 1406 ad annum 1450, 3 vols, Padova: Editrice Antenore, 1970.

GHezzo, Michele Pietro (ed.): Acta Graduum Academicorum Gymnasii Patavini. II/1: Ab anno 1451 ad annum 1460, Padova: Editrice Antenore, 1990.

GHezzo, Michele Pietro (ed.): Acta Graduum Academicorum Gymnasii Patavini. II/2: Ab anno 1461 ad annum 1470, Padova: Editrice Antenore, 1992.

Martellozzo Forin, Elda (ed.): Acta Graduum Academicorum Gymnasii Patavini. II/3-6: Ab anno 1471 ad annum 1500. 4 vols. (Fonti per la Storia dell' Universitá di Padova 17), RomaPadova: Editrice Antenore, 2001.

\section{Museums}

BM

DMW

GNM

HNG

$\mathrm{KM}$

$\mathrm{KSH}$

MA
British Museum, London

Dom Museum (earlier: Dom- und Diözesanmuseum), Vienna

Germanisches National Museum, Nüremberg

Magyar Nemzeti Galéria / Hungarian National Gallery, Budapest

Keresztény Múzeum / Christian Museum, Esztergom

Kunstsammlungen des Stiftes, Heiligenkreuz

Museum zu Allerheiligen, Schaffhausen 
MFA

NGP

ÖGB

StMWrN
Museum of Fine Arts, Boston

Národní Galerie v Praze / National Gallery of Prague, Prague

Österreichische Galerie Belvedere, Vienna

Stadtmuseum, Wiener Neustadt

\section{BIBLIOGRAPHY}

Aichinger-Rosenberger et al (Dehio) 2003 - AichingerRosenberger, Peter - Benedik, Christian: Niederösterreich südlich der Donau (Dehio-Handbuch: Die Kunstdenkmäler Österreichs; Topographisches Denkmälerinventar), Horn-Wien: Berger, 2003.

AlbreCher 1997 - AlbreCHER, Anton: Die landesfürstliche Visitation und Inquisition von 1528 in der Steiermark. Edition der Texte und Darstellung der Aussagen über die kirchlichen Zustände (Quellen zur geschichtlichen Landeskunde der Steiermark 13), Graz: Selbstverlag der Historischen Landeskommission für Steiermark, 1997.

ANDRITSCH 2001 - ANDRITSCH, Johann: Rechtsquellen zur Geschichte der Stadt Judenburg (Quellen zur Geschichtlichen Landeskunde der Steiermark 16), Graz: Selbstverlag der Historischen Landeskommission für Steiermark, 2001.

ANkwicz-KleEHOVEn 1955 - Ankwicz-KleEHOVEn, Hans: Alexius Funk, Bürgermeister von Wiener Neustadt, Unsere Heimat 26. 1955. 44-52.

BALDASS 1963 - BALDASS, Ludwig: Die Tafelmalerei, in Die Gotik in Niederösterreich. Kunst, Kultur und Geschichte eines Landes im Spätmittelalter, Hg. DwORSCHAK, Fritz - KüHNEL, Harry, Wien: Druck und Verlag der Österreichischen Staatsdruckerei, 1963. 81-91.

BASTL 1984 - BASTL, Beatrix: Fuggersche Kupfertransporte durch Neustadt und die wirtschaftlichen Beziehungen zum Handelshaus Alexius Funck, Unser Neustadt 28/4. 1984. 7-12.

BAtTenberg 1978 - BAtTenberg, Friedrich: Eine Darmstädter Manuskript zu Kammergerichtsordnung Kaiser Friedrichs III. vom Jahre 1471, Archiv für Hessische Geschichte und Altertumskunde NF 36. 1978. 37-62.

BAUCH 1976 - BAUCH, Kurt: Das mittelalterliche Grabbild: Figürliche Grabmäler des 11. bis 15. Jahrhunderts in Europa, Berlin-New York: De Gruyter, 1976.

Benesch 1930 - Benesch, Otto: Der Meister des Krainburger Altars, Wiener Jahrbuch für Kunstgeschichte 7. 1930. $120-200$.

BoeHEIm 1886 - Boeneim, Wendelin (Hg.): Urkunden und Regesten aus dem Stadt Archive zu Wiener Neustadt, Jahrbuch der Kunsthistorischen Sammlungen Bd. 4/2. 1886. 3-66.

BoeHeIm 1889 - BoeHeim, Wendelin: Maler und Werke der Malerkunst in Wiener-Neustadt im XV. Jahrhundert, Berichte und Mittheilungen des Alterthums-Vereines zu Wien 25. 1889. 75-102.

Boshof et al (Hgg.) $2003^{2}$ - Boshof, EGON - et al (Hgg.): Geschichte der Stadt Passau. (Revised from the original edition Regensburg: Pustet, 1999), Regensburg: Pustet, 2003.

Boskovits-Mojzer-Mucsi 1964 - Boskovits, Miklós MoJzer, Miklós - Mucsi, András: Az esztergomi Keresz- tény Múzeum képtára [Das Christliche Museum von Esztergom/Gran], Budapest: Akadémiai Kiadó / Verlag der Ungarischen Akademie der Wissenschaften, 1964 $\left(1967^{2}\right)$.

BRINKMANN-KEMPERDICK 2002 - BRINKMANN, Bodo - KEMPERDICK, Stephan: Deutsche Gemälde im Städel (Kataloge der Gemälde im Städelschen Kunstinstitut Frankfurt am Main IV), Mainz: Philipp von Zabern, 2002.

Burger (Hg.) 1961 - Burger, Helene (Hg.): Nürnberger Totengeläutbücher I: St. Sebald, 1437-1517 (Freie Schriftenfolge der Gesellschaft für Familienforschung in Franken 13), Neustadt/Aisch: Degener \& Co., 1961.

Burger (Hg.) 1967 - Burger, Helene (Hg.): Nürnberger Totengeläutbücher II: St. Lorenz, 1454-1517 (Freie Schriftenfolge der Gesellschaft für Familienforschung in Franken 16), Neustadt/Aisch: Degener \& Co., 1967.

Buttlar 1991/1992 - Buttlar, Gertrud: Das Epitaph des Wiener Neustädter Goldschmiedes Sigmund Walach (gest. 1450), Unsere Heimat: Zeitschrift für Landeskunde von Niederösterreich 62. 1991/1992. 217-229.

ButTlar 1995 - ButTlaR, Gertrud: Stadtmuseum Wiener Neustadt, Katalog, Wiener Neustadt: Merbod-Verlag, 1995.

Buttlar-ElberberG 1997 - Buttlar-ElberberG, Gertrud: Der St Leopolds-Altar im Dom zu Wiener Neustadt und seine Stifter, Jahrbuch des Stiftes Klosterneuburg NF 16. 1997. 23-39.

Chmel 1853 - Chmel, Joseph: II. Oesterreichische Geschichtsquellen. 5. Salzburgische Urkunden und Urkunden-Auszüge von 1440 bis 1457 aus dem k.k. Haus-, Hof- und Staatsarchive, in Notizenblatt. Beilage zum Archiv für Kunde österreichischer Geschichtsquellen, Wien: K.K. Hof- und Staatsdruckerei, 1853. 225-228.

CSENDES 1969 - CSENDES, Peter: Die Straßen Niederösterreichs im Früh- und Hochmittelalter (Dissertationen der Universität Wien 33), Wien: Verlag Notring, 1969.

Csendes-Opll (Hgg.) 2001 - Csendes, Peter - Opll, Ferdinand (Hgg.): Wien. Geschichte einer Stadt. Band 1: Von den Anfängen bis zur Ersten Türkenbelagerung, WienKöln-Weimar: Böhlau Verlag, 2001.

CsOrBA 1975 - CsOrBA, Csaba: Tulajdonjegyek, mesterjegyek, polgári címerek a középkorban [Eigentumszeichen, Meisterzeichen und Bürgerwappen im Mittelalter], A Hermann Ottó Múzeum évkönyve 13-14. 1975. 143-189.

Czeike et al (Hgg.) 1982 - CzEIKE, Felix - BAnIK-SChweItZer, Renate - Meissl, Gerhard - Opll, Ferdinand (Hgg.): Wiener Neustadt (Bearb. Gertrud GeRHARTL) (Österreichischer Städteatlas, 1. Lieferung), Wien: Wiener Stadt- und Landesarchiv - Ludwig Boltzmann Institut für Stadtgeschichtsforschung, 1982.

Czeike et al (Hgg.) 2002 - Czeike, Felix - BAnik-Schweitzer, Renate - MeISsL, Gerhard - Opll, Ferdinand (Hgg.): Judenburg. (Bearb. Wilhelm DeuER) (Österreichischer Städteatlas, 7. Lieferung), Wien: Wiener Stadt- und 
Landesarchiv - Ludwig Boltzmann Institut für Stadtgeschichtsforschung, 2002.

CZEIKE 1992-2004 - CZEIKE, Felix: Historisches Lexikon Wien, I-VI, Wien: Kremayr und Scheriau, 1992-1997, 2004.

DRASKÓCZY 2018 - DraSKóczy, István: A magyarországi kôsó bányászata és kereskedelme (1440-1530-as évek) [Salt Mining and Trade in Hungary (1440s-1530s)] (Magyar történelmi emlékek. Értekezések), Budapest: MTA BTK TTI, 2018.

DreXler 1955 - DreXler, Elfriede: Beiträge zum Bruderschaftswesen, mit besonderer Berücksichtigung der Fronleichnamsbruderschaft zu Wiener Neustadt, Dissertation, Universität Wien, 1955.

EICHHORN 1995 - EICHHORN, Gertraud: Die Passauer Bruderschaft Unser Lieben Frauen der Salzfertiger- und Schiffleutzech (Lampl-Bruderschaft). Ein Beitrag zu ihrer Geschichtsschreibung und Überlieferung, Ostbairische Grenzmarken 37. 1995. 81-102.

EICHLER 1906 - EICHLER, Ferdinand: Aus steirischen Missalien des 14. und 15. Jahrhunderts, Mitteilungen des Österreichischen Vereins für Bibliothekswesen 10/2. 1906. 53-69.

EIRICH 1971 - EIRICH, Raimund: Memmingens Wirtschaft und Patriziat von 1347 bis 1551. Eine wirtschafts- und sozialgeschichtliche Untersuchung über des Memminger Patriziat während der Zunftverfassung, Weißenhorn: Kommissionsverlag Anton H. Konrad Verlag, 1971.

ERHARD 1862-1864 - ERHARD, Alexander: Geschichte der Stadt Passau, I-II, Passau: Keppler, 1862-1864.

Facciolati 1757 - Facciolati, Jacobo (1682-1769): Fasti Gymnasii Patavini, Padova: Typis Seminarii, 1757.

FARKA 1977 - FARKA, Christa: Fundbericht: Wiener Neustadt, Fundberichte aus Österreich 16. 1977. 550-557.

FARKA 1978 - FARKA, Christa: Zur Baugeschichte des Domes von Wiener Neustadt. Bericht über die archäologischen Untersuchungen 1977-1978, Fundberichte aus Österreich 17. 1978. 25-44.

FARKA 1979 - FARKA, Christa: Archäologische Untersuchungen im Dom zu Wiener Neustadt, in Die Zeit der frühen Habsburger, Dome und Klöster 1279-1379. Ausstellungskatalog Wiener Neustadt 12. Mai bis 28. Oktober 1979, Hg. RÖHRIG, Floridus (Katalog des Niederösterreichischen Landesmuseums NF 85), Wien: Amt der Niederösterreichischen Landesregierung, 1979. 137-142.

FRICK 2003 - FRICK, Michaela: Ornament und Stil: Musterschablonen in der österreichischen Tafelmalerei des 15. Jahrhunderts, Ungedr. Phil. Dissertation, Universität Innsbruck, 2003.

Friedrich III. Kaiserresidenz 1966 - Friedrich III. Kaiserresidenz Wiener Neustadt. Ausstellung - St Peter an der Sperr Wiener Neustadt, Katalog (Katalog des N.-Ö.-Landesmuseums NF 29), Wien: Amt der Niederösterreichischen Landesregierung, 1966.

Frimmel 1913-1914 - Frimmel, Theodor: Lexikon der Wiener Gemäldesammlungen, Band 1-2, München: G. Müller, 1913-1914.

FronNer 1836 - Fronner, Johann Nepomuk (1784-1849): Monumenta Novae Civitatis Austriae: eorumdemque inscriptiones tum in arce Caesarea, tum in templis, claustris, aedificiis, in coemeterio; concinnata in quatuor libros. Vol. 3. De ecclesia parochiali primaria olim cathedrali episcopali, Faks. nach d. Orig. 1836, Wiener Neustadt: Merbod, 1991.
GentHon (ed.) 1948 - GentHon, István (ed.): Magyarország múemléki topográfiája I. Esztergom 1. Esztergom müemlékei [Topography of Art Monuments of Hungary I. Esztergom 1: Art Monuments of Esztergom], Budapest: Múemlékek Országos Bizottsága, 1948.

GERHARTL 1967 - GERHARTL, Gertrud: Florian Winkler, ein kaiserlicher Söldnerführer und Bürger der mittelalterlichen Stadt Wiener Neustadt, Jahrbuch für Landeskunde von Niederösterreich NF 37. 1967. 104-131.

GERHARTL 1978 - GERHARTL, Gertrud: Wiener Neustadt. Geschichte, Kunst, Kultur, Wirtschaft, Wien: Wilhalm Braumüller Universitäts-Verlagsbuchhandlung, 1978.

Gerhartl 1979 - GerharTL, Gertrud: Der Dom zu Wiener Neustadt, 1279-1979, Wien-Köln-Graz: Hermann Böhlaus Nachf. Gesellschaft, 1979.

GRIEB 2007 - GRIEB, Manfred H.: Nürnberger Künstlerlexikon. Bildende Künstler, Kunsthandwerker, Gelehrte, Sammler, Kulturschaffende und Mäzene vom 12. bis zur Mitte des 20. Jahrhunderts, München: K.G. Saur, 2007.

HAinisCH-WoisetsChlägER (Dehio) 1977 - HainisCH, Erwin - WoisetschlÄger, Kurt (Hgg.): Oberösterreich (DehioHandbuch: Die Kunstdenkmäler Österreichs; Topographisches Denkmälerinventar), Wien: Anton Schroll, 1977.

HAMmER 1959 - HAMmer, Lois: Aus Knittelfelds Vergangenheit, Knittelfeld: Aichfelder Zeitungs- und Verlagsgesellschaft, 1959

Harl 1954 - Harl, Elfriede von: Genealogische und wirtschaftliche Beziehungen zwischen Obersteiermark und Memmingen, Zeitschrift des Historischen Vereines für Steiermark 45. 1954. 150-153.

Heinig 1997 - Heinig, Paul-Joachim: Kaiser Friedrich III. (1440-1493). Hof, Regierung und Politik, I-III (Forschungen zur Kaiser- und Papstgeschichte des Mittelalters Beihefte zu J. F. Böhmer, Regesta Imperii 17), KölnWeimar-Wien: Böhlau Verlag, 1997.

Hofmann 2010 - Hofmann, Klaus: »Also stet ez in dem statpuech«. Die Wiener Neustädter Ratsbücher als geschichtswissenschaftliche Quellen, Pro Civitate Austriae: Informationen zur Stadtgeschichtsforschung in Österreich 16. 2010. 11-40.

HofFmAnN 1931 - HofFmann, Edit: Über Altäre aus Ungarn im 15. und 16. Jahrhundert, A Múgyújtố 5/6-7. 1931. $162-168$.

Homeyer 1870 - Homeyer, Carl Gustav: Die Haus- und Hofmarken, Berlin: Verlag der Königlichen Geheimen Oberhofbuchdruckerei, 1870.

Horn 2001 - Horn, Sonia: Examiniert und approbiert: die Wiener medizinische Fakultät und nicht-akademische Heilkundige in Spätmittelalter und früher Neuzeit, Dissertation, Universität Wien, 2001

Horn 2003 - Horn, Sonia: Normative Quellen zum Niederösterreichischen Gesundheitswesen in der Frühen Neuzeit. Ergebnisbericht OeNB-Projekt Nr. 8706, Universität Wien, 2003. The document is available online: http:// www.sonia-horn.eu/wp-content/uploads/2014/03/ Ergebnisbericht-OeNBEndversion.pdf (last accessed: 15.11.2018)

HöFler 1976 - HöFler, Janez: Zum ehemaligen Zwölfbotenaltar aus Wiener Neustadt, Österreichische Zeitschrift für Kunst und Denkmalpflege 30. 1976. 163-172. 
Hülsen-Esch 2006 - Hülsen-Esch, Andrea von: Gelehrte im Bild. Repräsentation, Darstellung und Wahrnehmung einer sozialen Gruppe im Mittelalter (Veröffentlichungen des Max-Planck-Instituts für Geschichte 201), Göttingen: Vandenhoeck \& Ruprecht, 2006.

JAQUET-Verelst-DaWson (eds.) 2016 - JAQUet, Daniel Verelst, Karin - Dawson, Timothy (eds.): Late Medieval and Early Modern Fight Books: Transmission and Tradition of Martial Arts in Europe (14 $4^{\text {th }}-17^{\text {th }}$ Centuries), Leiden-Boston: Brill, 2016.

JARITZ 1973 - JARITZ, Gerhard: Die Konventualen der Zisterzen Rein, Sittich und Neuberg im Mittelalter, Dissertation, Universität Graz, 1973.

KemPerdick 2004 - KemPerdick, Stephan: Martin Schongauer. Eine Monographie (Studien zu internationalen Architektur- und Kunstgeschichte 32), Petersberg: Michael Imhof Verlag, 2004.

KlaAr 1963 - KlaAr, Adalbert: Die Stilformen der Gotischen Stadt, in Die Gotik in Niederösterreich. Kunst, Kultur und Geschichte eines Landes im Spätmittelalter, Hg. DworschaK, Fritz - KüHnel, Harry, Wien: Druck und Verlag der Österreichischen Staatsdruckerei, 1963. 69-78.

Klemm 2010 - Klemm, Susanne: Montanarchäologische Forschung in der Eisenerzer Alpen, Steiermark. Bronzezeit bis Neuzeit, Forum Archaeologiae 54/III. 2010. http://farch.net (last accessed: 08.11.2018)

KNOLLE 1965 - KNOLLE, Ulrich: Studien zum Ursprung und zur Geschichte des Reichsfiskalats im 15. Jahrhundert, Dissertation, Freiburg im Breisgau, 1965.

KoHN 1998 - KoHN, Renate (gesammelt und bearbeitet): Die Inschriften des Bundeslandes Niederösterreich. Teil 2: Die Inschriften der Stadt Wiener Neustadt (Die Deutschen Inschriften 48. Wiener Reihe 3/2), Wien: Verlag der Österreichischen Akademie der Wissenschaften, 1998.

KoHN 2005 - KoHN, Renate: Zwischen standesgemäßem Repräsentationsbedürfnis und Sorge um das Seelheil. Die Entwicklung des frühneuzeitlichen Grabdenkmals, in Macht und Memoria: Begräbniskultur europäischer Oberschichten in der Frühen Neuzeit, Hg. HenGERER, Mark, Köln-Weimar-Wien: Böhlau Verlag, 2005. 19-46.

Koller 1979 - Koller, Manfred: Ergebnisse der Innenrestaurierung des Wiener Neustädter Domes, in Die Zeit der frühen Habsburger, Dome und Klöster 1279-1379. Ausstellungskatalog Wiener Neustadt 12. Mai bis 28. Oktober 1979, Hg. RÖHRIG, Floridus (Katalog des Niederösterreichischen Landesmuseums NF 85), Wien: Amt der Niederösterreichischen Landesregierung, 1979. 143-151.

Kotkova 2007 - KotKova, Olga: National Gallery in Prague - German and Austrian Painting of the $14^{\text {th }}-16^{\text {th }}$ Centuries (Illustrated Summary Catalogue II/1), Prague: National Gallery, 2007.

Kovács S. 2010 - Kovács S., Tibor: Huszárfegyverek a 15-17. században [Cavalry Weapons in the Fifteenth-Seventeenth Century], Budapest: Martin Opitz Kiadó, 2010.

KUBINYI 1973 - KuBINYI, András: Bicellus. Adatok egy középkori fegyverfajta meghatározásához [Bicellus. Beiträge zur Bestimmung einer mittelalterlichen Waffe], Budapest Régiségei 23. 1973. 189-193.

KuBINYI 1992 - KUBinYI, András: Der Eisenhandel in den ungarischen Städten des Mittelalters, in Stadt und Eisen,
Hg. Opll, Ferdinand (Beiträge zur Geschichte der Städte Mitteleuropas 11), Linz/Donau: Österreichischen Arbeitskreis für Stadtgeschichtsforschung - Ludwig Boltzmann Institut für Stadtgeschichtsforschung, 1992. 197-206.

KüHnEl (Hg.) 1967 - KüHnel, Harry (Hg.): Gotik in Österreich (Ausstellung 19. Mai bis 15 Oktober 1967, Minoritenkirche Krems-Stein, Niederösterreich), Krems: Jasper, 1967.

LaKatos-Balla 2012 - LaKatos-Balla, Attila: Ipolyi Arnold püspök hagyatéka Nagyváradon [Bishop Arnold Ipolyi's Legacy in Oradea (Nagyvárad/Grosswardein)] (Miscellanea Historica Varadiensia 3), Nagyvárad: Nagyváradi Római Katolikus Püspökség - Varadium Script Kiadó, 2012

LANC 1983 - LANC, Elga: Die mittelalterlichen Wandmalereien in Wien und Niederösterreich (Corpus der mittelalterlichen Wandmalereien Österreichs 1), Wien: Verlag der Österreichischen Akademie der Wissenschaften, 1983.

LeCHNER 1965 - LeCHNER, Anneliese: Das Wiener Neustädter Bürgerspital während des Mittelalters und der Frühen Neuzeit (14., 15. und 16. Jahrhundert), Dissertation, Universität Wien, 1965.

LindECK-PozzA 1953-1954 - LindECK-PozZA, Erich: Wiener Neustadts Streben nach der Vorherrschaft im Eisenhandel des südöstlichen Niederösterreich (bis zur Eisenordnung Maximilians II. 1574), Jahrbuch für Landeskunde von Niederösterreich NF 31. 1953-1954. 113-132.

LiNDNER 1975 - LiNDNER, Eveline: Wiener Neustädter Bürgermeister im 17. Jahrhundert. Georg Christoph Preydl (16341641), Georg Holzner (1642-1647), Christoph Kischinger (1648-1663), Dissertation, Universität Wien, 1975.

LOIBL 1995 - LOIBL, Richard: Passau als Salzhandelsstadt, in Salz macht Geschichte. Aufsätze, Hgg. TremL, Manfred - JAHN, Wolfgang - BlockHofF, Evamaria (Veröffentlichungen zur Bayerischen Geschichte und Kultur 29), Augsburg: Haus der Bayerisches Geschichte, 1995. 304-313.

MAESTRO 1995 - MAESTRO, Lucia: Spätmittelalterliche Bürgertestamente in den Wiener Neustädter Ratsbüchern als Quelle zur Alltagsgeschichte, Diplomarbeit, Universität Wien, 1995.

MaIER 1965 - Maier, Franz: Der Passauer Salzhandel im Mittelalter und zu Beginn der Neuzeit, Diplomarbeit, Nürnberg, 1965.

MAjorossy 2011 - MAjorossy, Judit: »I wish my body to hallowed ground «: Testamentary Orders of the Burghers of Late Medieval Pressburg about their Own Burial, in On Old Age. Approaching Death in Antiquity and in the Middle Ages, eds. Krötzl, Christian - Mustakallio, Katariina (Studies in the History of Daily Life (800-1600), HDL 2), Turnhout: Brepols Publisher, 2011. 89-124.

MAYER 1924-1928 - MAYER, Josef: Geschichte von Wiener Neustadt, I-IV, Wiener Neustadt: Selbstverlag des Stadtrates Wiener Neustadt, 1924-1928.

MAYER 1886 - MAYER, Josef: Regesten aus dem Archive des k. k. Kreisgerichtes zu Wiener Neustadt, Jahrbuch der Kunsthistorischen Sammlungen Bd. 4/2. 1886. 67-91.

Mell 1896 - Mell, Anton: Judenburger Haus-, Hof- und Siegelmarken, Mittheilungen der K. K. Central-Commission für Erforschung und Erhaltung der Kunst und historischen Denkmale NF 22. 1896. 21-30. 
Mérai 2017 - Mérai, Dóra: Memory from the Past, Display for the Future: Early Modern Funeral Monuments from the Transylvanian Principality, Doctoral Dissertation, Central European University, Budapest, 2017.

MoraW 1986 - Moraw, Peter: Die gelehrten Juristen der deutschen Könige im späten Mittelalter (1273-1493), in Die Rolle der Juristen bei der Entstehung des modernen Staates, Hg. Schnur, Roman, Berlin: Duncker \& Humblot, 1986. 77-147.

MÜller 1993 - Müller, Albert: Universitätsbesuch und städtische Herkunft. Forschungsprobleme am Beispiel österreichischer Städte und der Wiener Universität, 1377-1554, in Aspekte der Bildungs- und Universitätsgeschichte, 16. bis 19. Jahrhundert, Hg. MÜHLBERGER, Kurt - Maisel, Thomas (Schriftenreihe des Universitätsarchivs. Universität Wien 7), Wien: Universitätsarchiv, 1993. 332-360.

MÜller 1994 - Müller, Albert: Machtpositionen und Ordnungen. Zwei oder drei Bausteine zu einer Sozialgeschichte von Wiener Neustadt im Spätmittelalter, in Die Wienerische Neustadt: Handwerk, Handel und Militar in der Steinfeldstadt. Hgg. HaHn, Sylvia - Flanner, Karl, WienKöln-Weimar: Böhlau, 1994. 425-470, 532-542.

MÜller 2009 - Müller, Mathias F.: Bernhard Strigel: das Funk-Epitaph für die Domkirche zu Wiener Neustadt. Ein stilgeschichtlicher Beitrag zum Werk des Memminger Malers, Unser Neustadt: Blätter des Wiener Neustädter Denkmalschutzvereines 53/2. 2009. 1-16.

MÜller 2011 - Müller, Mathias F.: Der Meister von Mühldorf und die Devotionstafel des Johann Geumann aus dem Kapuzinerkloster zu Wiener Neustadt. Zeitliche Einordnung und stilistische Charakteristik, Unsere Heimat. Zeitschrift für Landeskunde von Niederösterreich 82/3-4. 2011. 210-215.

NAsChenweng 2016 - NaschenWeng, Hannes P.: Eine römische Ablassurkunde für Balthasar Eggenbergers Spitalkirche zu Allen Heiligen in Graz (1477), Zeitschrift des historischen Vereines für Steiermark 107. 2016. 231-237.

Niemetz 1985 - Niemetz, Georg: Das Handelshaus Alexius Funck auf dem Fischplatz im 15.-16. Jahrhundert, Unser Neustadt 29/1. 1985. 1-4.

Niemetz (Hg.) $2003^{2}$ - Niemetz, Georg (Hg.): Dom Wiener Neustadt (originally published in Wiener Neustadt: Verein zur Erhaltung der Kunstdenkmäler in Wiener Neustadt, 1954), Regensburg: Verlag Schnell \& Steiner, 2003.

Oberhaidacher 2012 - Oberhaidacher, Jörg: Die Wiener Tafelmalerei der Gotik um 1400: Werkgruppen - Maler Stile, Köln-Weimar-Wien: Böhlau Verlag, 2012.

OfNer 1966 - OfNer, Josef: Ein Nürnberger Druck aus dem 18. Jahrhundert, Oberösterreichische Heimatblätter 20/1-2. 1966. 63-70.

Отто 1964 - Отто, Gertrud: Bernhard Strigel, MünchenBerlin: Deutscher Kunstverlag, 1964

Palme 1983 - Palme, Rudolf: Rechts-, Wirtschafts- und Sozialgeschichte der inneralpinen Salzwerke bis zu deren Monopolisierung, Frankfurt am Main: Verlag Peter Lang, 1983.

Perger 1979 - Perger, Richard: Der Stifter der Maria im Ährenkleid im Christlichen Museum in Esztergom, Österreichische Zeitschrift für Kunst und Denkmalpflege 33. 1979. 16-18.
Perger 1997 - Perger, Richard: Die Frueauf-Gemälde im Klosterneuburger Stiftsmuseum: im Kunsthandel erworben?, Jahrbuch des Stiftes Klosterneuburg NF 16. 1997. 177-183.

PICKL 1966 - PICKL, Othmar: Das älteste Geschäftsbuch Österreichs: die Gewölberegister der Wiener Neustädter Firma Alexius Funck (1516-ca. 1538) und verwandtes Material zur Geschichte des steirischen Handels im 15.-16. Jahrhundert (Forschungen zur geschichtlichen Landeskunde der Steiermark 23), Graz: Verlag der Historischen Landeskommission, 1966.

PICKL 1967 - PICKL, Othmar: Die Memminger Handelsgesellschaft Funck und ihr Handel mit dem Südosten, Südostdeutsches Archiv 10. 1967. 108-131.

PICKL 1984 - PICKL, Othmar: Der Eisenhandel und seine Wege, in Erz und Eisen in der Grünen Mark. Beiträge zum steirischen Eisenwesen, Hg. RotH, Paul Werner (Beitragband zur Steirischen Landesausstellung "Erz und Eisen in der Grünen Mark", Eisenerz, 12. Mai bis 14. Oktober 1984), Graz: Kulturreferat der Steiermärkischen Landesregierung, 1984. 345-365.

PICKL 1992 - PICKL, Othmar: Die Rolle der österreichischen Städte für den Handel mit Eisen und Eisenwaren, in Stadt und Eisen, Hg. OplL, Ferdinand (Beiträge zur Geschichte der Städte Mitteleuropas 11), Linz/Donau: Österreichischen Arbeitskreis für Stadtgeschichtsforschung - Ludwig Boltzmann Institut für Stadtgeschichtsforschung, 1992. 171-196.

Pigler 1934 - Pigler, Andor: »Evagationes spiritus«. Egy képmagyarázat és adatok az esztergomi Keresztény Múzeum festményeinek történetéhez [Explonation to an image and data to the history of the paintings in the Christian Museum of Esztergom], Archaeologiai Értesitô (1932-1933) NS 46. 1934. 121-136, 207-208.

ReIDINGER 2001² - ReIDINGER, Erwin: Planung oder Zufall. Wiener Neustadt 1192 (originally published in Wiener Neustadt: Merbod-Verlag, 1995), Wien-Köln-Weimar: Böhlau Verlag, 2001².

Rausch (Hg.) 1988 - RAusch, Wilhelm (Hg.): Stadt und Salz (Beiträge zur Geschichte der Städte Mitteleuropas 10), Linz/Donau: Österreichischen Arbeitskreis für Stadtgeschichtsforschung - Ludwig Boltzmann Institut für Stadtgeschichtsforschung, 1988.

RinOFNER 2006 - RinOFNER, Hans: Die ehemalige Stadtpfarrkirche, Aus dem Stadtarchiv Knittelfeld. Geschichte und Geschichten von Knittelfeld 15. 2006. Februar. Available as online publication: https://knittelfeld.gv.at/leben-in-knittelfeld/home/servicemenue/gut-zu-wissen/ wissenswertes/historisches/archivbeilagen-stadtmagazin/ (last accessed: 30.08.2018)

RÖHrig (Hg.) 1979 - RöHRig, Floridus (Hg.): Die Zeit der frühen Habsburger, Dome und Klöster 1279-1379. Ausstellungskatalog Wiener Neustadt 12. Mai bis 28. Oktober 1979 (Katalog des Niederösterreichischen Landesmuseums NF 85), Wien: Amt der Niederösterreichischen Landesregierung, 1979

Popelka 1951-1963 - PopelkA, Fritz: Geschichte der Stadt Judenburg, Bände I-II, Unveröffentlichtes Manuskript (as a copy: ÖNB, 1.096.978/1-2), Judenburg, 1951-1963.

Rist 1994 - Rist, Helga: "Anna, Barbara, Christina...". Lebensbedingungen von Frauen im 14. und 15. Jahrhundert in Wiener Neustadt, Dissertation, Universität Wien, 1994. 
RIST 1998 - RIST, Helga: Leben für den Himmel. Spätmittelalterliche bürgerliche Seelgerätstiftungen aus Wiener Neustadt, in du guoter tốt. Sterben im Mittelalter - Ideal und Realität, Hg. Wenninger, Markus J. (Schriftenreihe der Akademie Friesach 3), Klagenfurt: Wieser Verlag, 1998. 215-235.

Rist 2005/2007 - Rist, Helga: Rechtssystem und Stadtgericht in Wiener Neustadt im Jahr 1604, Unsere Heimat. Zeitschrift des Vereins für Landeskunde von Niederösterreich 76/2-4. 2005/2007. 137-161.

SARKADI NAGY 2017 - SARKAdi Nagy, Emese: The Christian Museum's Online Catalogue of Medieval Works from Hungary and the German and Austrian Territories, Esztergom: Christian Museum, 2017. http://www.keresztenymuzeum.hu/collections.php? mode $=$ intro\&cid $=11 \& v t=$ (last accessed: 10.10.2018)

Scheutz et al (Hgg.) 1997 - ScheutZ, Martin - SCHMUtZER, Kurt - SPevak, Stefan - StÖger, Gabriele (Hgg.): Wiener Neustädter Handwerksordnungen (1432 bis Mitte des 16. Jahrhunderts) (ÖAW Philosophisch-historische KlasseKommission für Rechtsgeschichte Österreichs Fontes Rerum Austriacarum Dritte Abteilung: Fontes Iuris 13), Wien-Köln-Weimar: Böhlau, 1997.

SCHLEIF-SCHIER 2009 - SCHLEIF, Corine - SCHIER, Volker: Katerina's Windows: Donation and Devotion, Art and Music, as Heard and Seen through the Writings of a Birgittine Nun, University Park: Penn State Press, 2009.

SCHOBER 1885 - SCHOBER, Karl: Das bürgerliche Leben zu Wiener-Neustadt im Zeitalter Friedrichs IV., Blätter des Vereins für Landeskunde von Niederösterreich NF 19. 1885. 224-259.

Schoenen 1967 - Schoenen, Paul: Epitaph, in Reallexikon zur deutschen Kunstgeschichte, München: Zentralinstitut für Kunstgeschichte, 1937-2014. Vol. 5. 1967. 872-921.

SEIDL 1987 - SeIDL, Christina: Beiträge zur Wiener und Niederösterreichischen Tafelmalerei der zweiten Hälfte des 15. Jahrhunderts, I-III, Dissertation, Universität Wien, 1987.

SIMON 2002 - SIMON, Achim: Österreichische Tafelmalerei der Spätgotik. Der niederländische Einfluß im 15. Jahrhundert, Berlin: Reimer, 2002.

SkVARICS 2000 - SkVARICS, Helga: Volksfrömmigkeit und Alltagskultur. Zum Stiftungsgeschehen Wiener Neustädter Bürger im Spätmittelalter und in der frühen Neuzeit (14. Jh.-16. Jh.) (Beiträge zur Neueren Geschichte Österreichs 15), Frankfurt am Main-Berlin-Bern-BruxellesNew York-Oxford-Wien: Peter Lang, 2000.

SONNTAG 1844 - SonntaG, J. V.: Knittelfeld in Obersteiermark. Ein Beitrag zur Vaterlandskunde, Grätz: Tanzerischen Schriften, 1844

SPROGER 2019 - SPROGER, Sylvia: Das Eggenberger Flügelretabel. Eine Frömmigkeits- und Identifikationsmatrix seines Stifterehepaares Balthasar und Radegunde Eggenberger. Wien-Köln-Weimar: Böhlau Verlag, 2019.

SPRUTH 1960 - SPRUTH, Herbert: Die Hausmarke. Wesen und Bibliographie (Aktuelle Themen zur Genealogie Heft 4/5), Neustadt an der Aisch: Verlag Degener, 1960.

Stange 1961 - Stange, Alfred: Deutsche Malerei der Gotik. Vol. 11. Österreich und der ostdeutsche Siedlungsraum von Danzig bis Siebenbürgen in der Zeit von 1400 bis 1500, München-Berlin: Deutscher Kunstverlag, 1961.

StaUb 1890-1891 - StaUb, Franz: Notizen zur Baugeschichte der Liebfrauenkirche in Wiener Neustadt, Teil
I-II., Berichte und Mittheilungen des Alterthums-Vereines zu Wien 26. 1890. 129-136; 27. 1891. 157-174.

Staub 1894 - Staub, Franz: Notizen zur Baugeschichte der Liebfrauenkirche in Wiener Neustadt, Berichte und Mittheilungen des Alterthums-Vereines zu Wien 30. 1894. 27-66.

Staub 1895 - Staub, Franz: Die Bürgertestamente der Wiener-Neustädter Rathsprotokolle. Ein Beitrag zur Culturgeschichte Niederösterreichs im ausgehenden Mittelalter, Blätter des Vereins für Landeskunde von Niederösterreich NF 29. 1895. 463-531.

Staub 1899 - Staub, Franz: Die Restaurierung der Liebfrauenkirche zu Wiener Neustadt, Berichte und Mittheilungen des Alterthums-Vereines zu Wien 34. 1899. 75-85.

Staub 1995 - Staub, Martial: Memoria im Dienst von Gemeinwohl und Öffentlichkeit. Stiftungspraxis und kultureller Wandel in Nürnberg um 1500, in Memoria als Kultur, Hg. Oexle, Otto Gerhard (Veröffentlichungen des Max-Planck-Instituts für Geschichte 121), Göttingen: Vandenhoeck \& Ruprecht, 1995. 285-334.

SuCKAlE 2004 - SuCKale, Robert: Der Maler Johannes Siebenbürger (um 1440-1483) als Vermittler Nürnberger Kunst nach Ostmitteleuropa, in Die Länder der böhmischen Krone und ihre Nachbarn zur Zeit der Jagiellonenkönige (1471-1526), Hg. WetTER, Evelin (Studia Jagellonica Lipsiensia 2), Ostfildern: Thorbecke, 2004. 363-384.

SuCKALE 2009 - SuCKale, Robert: Die Erneuerung der Malkunst vor Dürer, I-II, Petersberg: Michael Imhof Verlag, 2009

Suida 1911-1914 - Suida, Wilhelm: Österreichische Kunstschätze, I-III, Wien: Kunst und Verlagsanstalt J. Löwy, 1911-1914.

TAKÁCS 1991 - TAKÁCS, Imre: A budapesti Eligius-táblakép: a bécsi késô-gótikus festészet ismeretlen emléke [The Eligius Epitaph of Budapest: an Unknown Remnant of the Viennese Late Gothic Painting], in Annales de la Galerie Nationale Hongroise, Budapest: Magyar Nemzeti Galéria: 1991. 85-94.

TUISL 2014 - TuISL, Elisabeth: Die medizinische Fakultät der Universität Wien im Mittelalter: Von der Gründung der Universität 1365 bis zum Tod Kaiser Maximilians I. 1519 , Göttingen: V\&R Unipress, 2014

WACHAUF 1972 - WACHAUF, Helmut: Nürnbergers Bürger als Juristen, Erlangen: Universität Erlangen-Nürnberg, 1972.

WARNER 2018 - WARNER, Lyndan: Seeing Stepfamilies in European Visual Culture, in Stepfamilies in Europe, 1400 1800, ed. Warner, Lyndan, Milton: Routledge, 2018. 204-232.

WeCKWERTH 1957 - WeCKWERTH, Alfred: Der Ursprung des Bildepitaphs, Zeitschrift für Kunstgeschichte 20/2. 1957. 147-185.

WeILANDT 2007 - WeILANDT, Gerhard: Die Sebalduskirche in Nürnberg: Bild und Gesellschaft im Zeitalter der Gotik und Renaissance (Studien zur internationalen Architekturund Kunstgeschichte 47), Petersberg: Michael Imhof Verlag, 2007.

WeISS 2002 - WeISS, Norbert: Das Städtewesen der ehemaligen Untersteiermark im Mittelalter. Vergleichende Analyse von Quellen zur Rechts-, Wirtschafts- und Sozialgeschichte (Forschungen zur Geschichtlichen Landeskunde der Steiermark 46), Graz: Selbstverlag der Historischen Landeskommission für Steiermark, 2002. 
Winkelbauer 1949 - Winkelbauer, Walter Franz: Der St. Georgs-Ritterorden Kaiser Friedrichs III., Dissertation, Universität Wien, 1949.

Winner 1962 - Winner, Gerhard: Das Diözesanarchiv St. Pölten. Behörden und Institutionen. Ihre Geschichte und ihre Bestände, St. Pölten: Bischöfliches Ordinariat, 1962.

WoISETSCHLÄGER et al (Dehio) 2006 - WOISETSCHLÄGER, Kurt - Krenn, Peter (Hgg.): Steiermark (ohne Graz) (DehioHandbuch: Die Kunstdenkmäler Österreichs; Topographisches Denkmälerinventar), Horn-Wien: Berger, 2006.

Wurster et al (Hgg.) 1995 - Wurster, Herbert W. - BrunNer, Max - Loibl, Richard - Brunner, Alois (Hgg.): Weisses Gold. Passau - Vom Reichtum einer europäischen Stadt (Katalog zur Ausstellung von Stadt und Diözese Passau im Oberhausmuseum Passau, 6. Mai bis 1. Oktober 1995), Passau: Passavia, 1995.

Wünsch 1910 - Wünsch, Joseph: Blasius Höfel. Geschichte seines Lebens und seiner Kunst und Verzeichnis seiner Werke, Wien: Gesellschaft für Vervielfältigende Kunst, 1910.
ZajIC 2004 - ZAJIC, Andreas: "Zu ewiger gedächtnis aufgericht." Grabdenkmäler als Quelle für Memoria und Repräsentation von Adel und Bürgertum im Spätmittelalter und in der Frühen Neuzeit. Das Beispiel Niederösterreichs (MIÖG, Ergänzungsband 45), Wien-München: R. Oldenbourg Verlag, 2004.

Zajic 2009 - ZajIC, Andreas: Ein Genealoge als Epigraphiker oder: Provisorisches zu ÖNB Cod. 9221, einer bislang unerkannten Inschriftensammlung Valentin Preuenhuebers, in Festschrift für Walter Aspernig zum 70. Geburtstag, Hgg. HeilingSeTZer, Georg - Kalliauer, Günter - PROKISCH, Bernhard (Jahrbuch des Oberösterreichischen Musealvereines, Gesellschaft für Landeskunde 157), Linz: OÖMV-GFLK, 2009. 363-390.

ZEINER 2012 - ZEINER, Irene: Jüdische und christliche Stadtbevölkerung im mittelalterlichen Wiener Neustadt. Die Rolle von Stadtarchitektur und visuellen Medien in Zusammenleben und in der Interaktion von Juden und Christen im Herzogtum Österreich, Diplomarbeit, Universität Wien, 2012.

\section{NOTES}

${ }^{1}$ The preparation of the study was supported by the following projects: Integrating Families Research Project of the Hungarian Academy of Sciences (MTA BTK Lendület); Special Research Programme (SFB 42) Visions of Community (VISCOM), P06: Social and Cultural Communities across Monastic, Urban, and Courtly Cultures in High and Late Medieval Central Europe funded by the Austrian Science Fund (FWF); Premium Postdoctoral Research Fund of the Hungarian Academy of Sciences (MTA PPD 462027) and the grant Complex Improvement of Research Capacities and Services at the Károly Eszterházy University (EFOP-3.6 1-16-2016-00001).

${ }^{2}$ Esztergom, KM, inv. no. 56.509. Tempera on wood, the panel is made of two wide boards (of silver fir); it measures $180 \times 120 \mathrm{~cm}$ in its original frame. For a short description, see the homepage of the Christian Museum of Esztergom: https://www.keresztenymuzeum.hu/collections.php?mode= work\&wid=399\&page=0\&vt $=$ (last accessed: 15.03 .2019$)$.

${ }^{3}$ The name appears in the literature in various forms, such as Hainperger, Heimperger, Heinperger. Verzeichniss 1839, 11 (see note 5) in: Frimmel 1913-1914, Bd. 2. 174-175; Hoffmann 1931, 169; Pigler 1934, 130-131; Genthon (ed.) 1948, 129; Boskovits-MoJzer-Mucsi 1964, 170-171; CsORBA 1975, 178. For the first correct identification: KoHN 1998, 92-93.

${ }^{4}$ On Blasius Höfel's personality and interests: WüNSCH 1910.

${ }^{5}$ Frimmel 1913-1914, Bd. 2. 172. A small catalogue was put together for the auction: "Verzeichniss einer Sammlung altdeutscher Gemählde welche Montag den [...] 1839 und die folgende Tage, Vormittag von 8 bis 2 Uhr durch das Bücher- und Kunstsachen Auctions-Institut Stadt Bürgerspital Nr. 1100 9. Hof versteigerungsweise hindangegeben werden. Wien: Gedruckt bei Joseph Edlen v. Schmidbauer, 1839." Published in: Frimmel 1913-1914, Bd. 2. 173-180. In this list the husband's name also appears incorrectly: "11. Ein Votiv Gemählde, mit der im Bilde selbst gemahlten Jah- reszahl 1498. Es ist 5 Schuh 9 Zoll hoch und 3 Schuh 10 Zoll breit, ganz gut conservirt, stellt den Tod Maria, umgeben mit den zwölf Aposteln vor, alle Figuren sind halb-lebensgross. An dem unteren Rande des Bildes knieet links der Stifter, und rechts dessen Familie bestehend aus acht Figuren, diese sind in ganz kleinem Masstabe und haben zwey Wappen; im Hintergrunde zeigt sich ein kleiner Goldgrund mit Zeirathen [sic!]. Dieses Gemählde hat die originale ganz gleichzeitige Rahm mit folgender Unterschrift Anno Domi [sic!] 1498 am Freytag St Matthias-Abend ist gestorben die ehrsame Frau des hochgelarten Stephan Heimperger, Lehrer zu den siehen freyen Künsten und Burger zu der Neustadt N. N. dieses Gemählde ist im reinsten Typus jener Zeit." FRIMMEL 1913-1914, Bd. 2. 174-175.

${ }^{6}$ The inventory of the Ipolyi collection from 1917 states the following in Hungarian [an English translation is provided in brackets]: "99. Mortuarium: Mária halála, mozgalmas jelenet gyanánt megfestve [Mortuarium: the death of the Virgin Mary, painted as a busy scene]. Mária vörös függönyú ágyban fekszik [Mary is lying in a bed with red curtains]; az ágy lábánál térdelố család látható, egyfelól férfi, másfelôl anya és hét gyermeke [at the foot of the bed a kneeling family can be seen; on one side a man, on the other a mother with her seven children]. Alul felirat [The text below reads]: Anno Domini 1496. Am freytag Sand Mathias abendt ist gestorben. Die ersam Fraw [...]hiroltin des wolgelerten Steffan Heinperger lerer in den Siben frewen [...] Burger zu der [...] stat sliche [sic!] hausfrau geweseh ist. Deszkán, egykorú keretben [On a wooden panel, in a contemporary frame]." LAKATOS-BALla 2012, 291.

${ }^{7}$ Rather similar clothing is visible, for example, in the epitaph of Professor Johannes Geuss from 1447, originally placed above his grave in the Friedrichschor of the Stephansdom in Vienna, today preserved in the Dom Museum Wien (DMW). Csendes-Opll (Hgg.) 2001, 367. In manuscripts depicting Viennese university (teaching) scenes, the professors are also represented in red robes with white collars and 
birettas. Vienna, ÖNB, Cod. 3145, fol. 1r; Cod. 2765, fol. 1r. Generally, on the representation of learned people in the Middle Ages (with French and Italian examples): HüLSENEsCH 2006, 61-202, especially 105-106 (the red clothing of doctors).

${ }^{8}$ Kubinyi 1973, 189-191; Kovács S. 2010, 113.

${ }^{9}$ Homeyer 1870, 170-176, 187-193. For further bibliography: SPRUTH 1960, 58-59, especially for Austria (and Styria). For a general summary on the different types: CSORBA 1975. The particular mark depicted on this epitaph will be discussed later.

${ }^{10}$ The word is no longer legible today, since the wood in that part of the frame is very badly damaged. However, the information discovered during research suggests the missing word must have been "artzney" or "ertzney". This was also assumed by Renate Kohn, who was the only scholar to properly identify the donor as Stephan Geinperger (KoHN 1998, 92-93).

${ }^{11}$ The other female epitaph known to us is the one commissioned by Sigmund Walach/Waloch - a goldsmith of Transylvanian origin who had already moved to Wiener Neustadt before 1430 and continued to work and live there, acting as councillor and performing several other urban functions (such as captain of the Ungartor and church warden of the parish church of Zemendorf) - for his first wife, Elisabeth, who died in 1434. Walach later twice remarried, but he appeared in the epitaph of his first wife. This panel, once also part of the Höfel collection, has similar dimensions to the later Geroltin epitaph and was painted in a wellknown Viennese workshop, that of the so-called St Lambrecht votive panel. Today it is preserved in Prague, in the National Gallery: Prague, NGP, inv. no. DO 4597; it measures $179 \times 141 \mathrm{~cm}$ in its original frame. For the description of the panel with earlier art historical literature: KоткоVA 2007, 97 (cat. no. 51). See also: MAYER 1924-1928, I/2. 467-468; Gerhartl 1978, 150; Buttlar 1991/1992, 217-229; KOHN 1998, 16-17 (no. 24); KoHn 2005, 26 (note 20); OBERHAIDACHER 2012, 231.

12 KoHn 1998, 92-93.

${ }^{13}$ In the sources both the Gerolt and the Gerold versions are present, while in the secondary literature either Gerolt or Gerold was used. We use the Gerolt version as this is how the woman's family name appeared on the epitaph.

${ }^{14}$ PICKL 1992, 171-180. The area from where the family originates, the Judenburg-Knittelfeld basin, together with the further territories (e.g. Eisenerz) of the Alps in northern Styria, was rich in iron ore mines (see KLEMM 2010). We should differentiate between bog iron and iron ore. The first type develops in bogs and swamps and appears as a spring. In this case, iron could be produced by smelting, which made it possible for villages to produce iron for local use. The second type is found in rocks and minerals, from which metallic iron can be economically extracted. This requires technology and investment, which accompany certain kinds of urban development. See also PiCKL 1984; KUBinyI 1992.

15 The chapel of St Catherine inside the church was founded by an influential local family, the Muerers. This beneficium was first endowed in 1452 by Anna, the widow of Peter Muerer, and later by Gotthard Muerer in 1479, and the chapel was finally built in 1481. Graz, StLA, A. Knittelfeld Stadt K. 77. H. 342 (Mss by Lois Hammer 1951), p3; SONNTAG 1844, 30; HAMmer 1959, 406-411.
${ }^{16}$ An obvious hint is the presence of iron ore pieces on the ground around the figures. The carving itself is still visible today in the new part of the local parish church, which was erected after the medieval building was bombed in World War II. RINOFNER 2006.

17 SONNTAG 1844; HAMMER 1959

${ }^{18}$ Harl 1954; LindeCK-Pozza 1953-1954; Popelka 19511963; PICKL 1966; PICKL 1967; EIRICH 1971; PICKL 1992; WeIss 2002. Nevertheless, the Wiener Neustadt element of the family history is less frequently touched upon. On the other hand, the works linking Dorothea Gerolt to Wiener Neustadt do not mention the family's Styrian origins in Knittelfeld.

${ }^{19}$ CSENDES 1969, 242-248.

${ }^{20}$ According to the estimations for the 1520s, the local parish community had approximately 1000 members who were served by six to seven priests. There were still six medieval altar and perpetual mass foundations recorded during the church visitation of 1528. Graz, StLA, A. Knittelfeld Stadt K. 77. H. 341 (Mss by Paul Dedic 1943), p2; Graz, StLA, A. Knittelfeld Stadt K. 77. H. 342 (Mss by Lois HamMER 1951), pp3-4. See also Albrecher 1997, 307.

${ }^{21}$ ANDRITSCH 2001, 19-20 (no. 16). The privilege of Judenburg was issued in 1277 and further statutes are known from 1298 (such as the privilege issued for Murau). ANDRITSCH 2001, 12-14 (no. 12), 17-19 (no. 15). For the medieval history of Judenburg, see: PopelkA 1951-1963; CZEIKE et al (Hgg.) 2002 (Städteatlas-Judenburg). Also available online: https://www.arcanum.hu/hu/online-kiadvanyok/OsterreichischerStadtatlas-osterreichischer-stadteatlas-1/judenburg-1C3 C/ (last accessed: 15.11.2018).

22 SonNTAG 1844, 41; HAMmer 1959, 151, 205-206; POPELKA 1951-1963, 338-339

${ }^{23}$ HAMmer 1959, 304 (school), 319-320, 413 (hospital).

24 "Maister Jacob Gerolt der gaistlichn rechten doctor vnnd pfarrer zu Knütlfeld": Diözesanarchiv Graz Seckau, Pfarrurkunden, II-165b (12 October 1489, he sold a few parcels of land from his family's estate); II-165c (17 October 1489, Mert Karner and his wife established a perpetual mass foundation - "ein ewigen jartag" - in the parish church of St John on those lands bought from Jakob Gerolt); II165a (28 October 1489, Wolfgang Schmid, hospital master, exchanged a parcel of land with Jakob Gerolt). The document was used from www.monasterium.net (last accessed: 20.03.2018). In the collection of Lois Hammer, a shorter time in office is stated: Graz, StLA, A. Knittelfeld Stadt K. 77. H. 342 (Mss by Lois Hammer 1951), p 2 (1480-1488 Magister Jacobus Gerold, Pfarrer in Knittelfeld), but a land register (Urbar) dating to 1490 was still prepared by him while he held this office (Graz, StLA, A. Knittelfeld Stadt K. 77. H. 351, 1490). On the other hand, during this time he also studied in Padua, and later, between 1487-1488, he was the rector of the faculty of law there: Padua, UPa, AGA II/3, 48 (Iacobus Giroldus Stiriensis), 253 (Geroldo Iacopo Stiriensis rettore dei giuristi); Facciolati 1757, 16. In 1492 ( 2 October) a document written by Jakob Gerolt himself discusses several issues concerning the parish church of Knittelfeld. Because he was no longer the parish priest of Knittelfeld, but in the Augustinian canonry (much later a Benedictine monastery) of Seckau, which served as a cathedral chapter for the bishopric, his successor, Lawrence Zwikhel, should have taken over this office and his former 
obligations. The document is published: EICHLER 1906, 66-69.

${ }^{25}$ Vienna, UAW, Matrikel Wien 2, 131 (Natio Australium, line 55-56) (Immatriculatio); Vienna, UAW, AFA III/2, 28 (Determinatio); Vienna, UAW, AFA III/2, 55 (Inceptio). See also RAG Datenbank: http://www.rag-online.org/de/datenbank (last accessed: 25.07.2018). During these years the second husband of Dorothea Gerolt also attended the university in Vienna (see below).

${ }^{26}$ Hammer 1959, 55 (1480), 58 (1489), 254 (1480), 362 (1488), 407 (1489), 408 (1480), 411 (1490), 421 (1479).

${ }^{27}$ Mistakenly written by V. J. Sonntag as Passau (Padova - Pataviensis, Patavium; Passau - Patavia, Batavia), where he was stated to be a schoolmaster (SonNTAG 1844, 39). This was corrected by Ferdinand Eichler, who also published a few documents concerning Jakob Gerolt's time in Padova $(1484,1488)$ in the appendix of his work: EICHLER 1906, 56 (note 9), 63-65. For his time in Padova see also Hammer 1959, 408.

28 "Geroldus Iacobus Stiriensis (Styrus) Knuelfeldensis (Cnitelfeldensis) doctor artium legumque scholar rector universitatis iuristarum"; "rector ecclesie S. Ioannis Decollati oppida Cnitelfeldi, doctor artium et licentiatus iuris"; "doctor artium et iuris canonici". Padua, UPa, AGA II/6, 1649. As rector of the law faculty, he appeared at several examinations and in doctoral committees between 20 June 1487 and 28 June 1488: Padua, UPa, AGA II/5, 859-860 (no. 1165 , no. 1167 ), 866-867 (no. 1175 , no. 1177 , no. 1178), 870-873 (no. 1183, no. 1185, no. 1188, no. 1191), 881-882 (no. 1203, no. 1204, no. 1205), 884-885 (no. 1209, no. 1211), 887-889 (no. 1216, no. 1218 - "artium doctor et iuratus scholaris dominus Iacobus Gerold universitas legistarum et canonistarum rector", no. 1220), 891 (no. 1223), 893 (no. 1225), 895-897 (no. 1228, no. 1229, no. 1231), 899-902 (no. 1235, no. 1237, no. 1239). Among these university documents, 28 June 1488 is the last time he appeared among the "Testes" at an examination: Padua, UPa, AGA II/5, 912-913 (no. 1256).

${ }^{29}$ This fact was mentioned in both of his letters sent to the provost of Seckau. Published by EICHLER 1906, 63-65. The first was written during his time as a student (12 December 1484), and the second when he was the rector (4 January 1488). In the second, he also mentioned that his brother, Valentine Gerolt, was in charge of taking care of the matters in Knittelfeld: "[...] super qua re omnem in temporalibus fratri meo Valentino auctoritatem dedi et vellem, quod vestra gratia dignaretur illi vobis presentando omnem auctoritatem meo nomine etiam in spiritualibus trader illam exoro, ut hoc ex sua humanitate facere dignetur cum pro hac re frater meus predictus vel eius nuncius venerit."

${ }^{30} \mathrm{He}$ signed the above (note 29), first letter as "Jacobus Gerolt, plebanus ecclesie S. Johannis decollatis in Chnutelfeld"; and the second, during his rectorate, as "Jacobus Geroldus Patavini gymnasii iuristarum rector, atque ecclesie S. Joannis decollatis in opido Cnitelfeldo plebanus".

${ }^{31}$ Graz, StLA, A. Knittelfeld Stadt K. 77. H. 349 (originally Hs. 69), Urbar 1483 - "Nota das Urbare puech [...] pharrer der pharrkyrchen sand Johannis Gotstawffer sand Veyt vnd sand Vlreich des heyligen bischouen der stat Knütelfelden ist vberschriben [...] durch mich, mayster Jacoben Gerolt dyezeyt pharrer daselbs ausgelassen worden". Graz, StLA, A. Knittelfeld Stadt K. 77. H. 350, Urbar 1489 - whose town book contains a lot of information about the family properties in the town. Graz, StLA, A. Knittelfeld Stadt K. 77. H. 351, Urbar 1490.

32 Graz, StLA, A. Knittelfeld Stadt K. 77. H. 342 (Mss by Lois Hammer 1951), p3. The chancel in the church was started in 1435 and was consecrated in 1451, while the nave was finished during the ensuing decades. WOISETSCHLÄGER et al (Dehio) 2006, 227-230.

${ }^{33}$ Hammer 1959, 407. It is also mentioned that the church tower was constructed that year: Graz, StLA, A. Knittelfeld Stadt K. 77. H. 350 (Urban 1489), fol. 138r.

${ }^{34}$ EICHLER 1906, 66. For his gravestone, seen and described in the parish church of Knittelfeld: SONNTAG 1844 , 70-71 (stating that the inscription was so damaged that the author was not able to transcribe its text with the date of his death). For this text, see also note 76.

${ }^{35}$ Graz, UBG, MS 74 (Alte Sign. 37/18), fol. 2r. EICHLER 1906, 53-69. See also Hans ZOTTER's description of this manuscript online: http://sosa2.uni-graz.at/sosa/katalog/ katalogisate/74.html (last accessed: 08.03.2018).

${ }^{36}$ HAMmer 1959, 55-58.

37 PICKL 1992. From Eisenerz, one iron trade route ran towards Upper Austria (Steyr), and from there to the north, towards Bohemia and Poland (via Freistadt or Krems) and also to the west. Another route passed through Vienna, Moravia and Hungary (Murau, Judenburg, Knittelfeld, Leoben and Wiener Neustadt).

${ }^{38}$ HAMmer 1959, 368 (the Gerolts are documented from the 1440 s onwards at the "Hammer an der Gleinbach"), 370 (Jakob Gerolt - probably the grandfather of Dorothea Gerolt - already in 1445 had an "Eisenhammer an der Glein"). Concerning the next generation, the property register of 1489 , prepared by Jakob Gerolt, also mentioned in several places relevant immovable properties in the hands of his own brothers. Graz, StLA, A. Knittelfeld Stadt K. 77. H. 350 (Urban 1489), fol. 63r: "[...] ain ort an meines brüeder Andre Gerolt grund der vormal ain angerel [sic!] ist gewest an sein hamerhaws vnd das wasser das selbig angerel vnd hamer hinwekch gewaschen stost auch an die strassen [...]"; fol. 96r: "[...] anger habent yetz ynnen mein brueder Bernhardin Gerolt vnd Mathias Brügkler zu irem hamer [...]"; fol. 126r: "[...] ort in des Wernhardin Gerolt meines brüeder wisen vnd mit dem oberen ort an des Valtein Gerolt auch meines brüeder wisen bey sein strekchhamerlen [...]"; fol. 137r: "[...] der ander grund ist ain akcher ligt am steig der am hamer get am Glain [...]". For Valentin Gerolt's sledgehammer in the Haffengasse, see also: HAMmER 1959, 410.

${ }^{39}$ According to Fritz Popelka, the Gerolts were (also) involved in livestock trade and were butchers. This latter piece of information is based only on the fact that a certain Michael Gerolt owned a shamble in Judenburg in 1489 (PopelKa 1951-1963, II. 337; Graz, StLA AUR 8434). Also Valentin Gerolt had shambles in Knittelfeld and later in Judenburg (HAMmER 1959, 206). The ownership of a shamble, however, is not necessarily strong proof of profession. However, as they were involved in trade in general, the family certainly could have benefited from the royal privilege of operating a leather trade and, in this respect, might have been involved in animal trade. The Upper Styrian towns those in the valley of the river Mur (Murtal), such as Judenburg, Knittelfeld, Leoben, Bruck an der Mur, Kindberg and Mürzzuschlag - were granted the privilege to process and 
trade in leather in 1357 , a right that was strengthened by Albert III in 1373. POPELKA 1951-1963, II. 424.

${ }^{40}$ HAMMER 1959, 167-169.

${ }^{41}$ Hammer 1959, 168.

42 The mark appearing on the epitaph was first published by Renate Kohn (KoHN 1998, 313, Anhang 1, Nr. 3), although the "Geroldische Wappen" had already been described earlier by Lois Hammer (HAMmer 1959, 168). This Hausmarke was also visible on the gravestone of parish priest Jakob Gerolt, which had been in the church crypt (but must have perished in the nineteenth century) and was therefore documented as early as 1844 (SonNTAG 1844, 70 with a drawing of the sign as seen on the grave slab). Interestingly, the same Jakob Gerolt, depicted as a kneeling donor on the cover folio of his missal, did not have the family house mark on the coat of arms by his knees but rather an image of his patron saint (see Fig. 6). Graz, UBG, MS 74 (Alte Sign. 37/18), fol. 1r. Nevertheless, the same family sign is painted onto the edge (Schnitt), the cover and the verso of the cover of a book bought by a family member, probably Jakob himself, in Venice ("+IHS 1477 a d(ie) primo czwgno [1 June 1477] chke mi a co(m)prado sto libro in Venesia") and which was later used as the confraternity book of the Corpus Christi brotherhood in Knittelfeld. Graz, StLA, A. Knittelfeld Stadt K. 84. H. 406, cover and fol. 1v. Finally, the Hausmarke is also visible on the seal of Valentin Gerolt, at the time judge of Judenburg. Mell 1896, 26 (the drawing is not a mirror image but shows the seal print on the document).

${ }^{43} \mathrm{He}$ bequeathed a mass at the altar of the merchants' guild: "Item mein weingertl gelegen zu Rustin der Wissen neben dem Pöltel, schaff ich in der kramer zech, Sannd Wolfgangs, vnd Sand Dorothe, in der maynung daz ein yeder zechmeister der benanten zeche darob sein sol [...] ein gesungens selampt in der pfarkirchen auf Sand Dorothe altar singen lassen." WNStA, Ratsbuch II, fol. 252r (p225). WNStA, Ratsbuch I, 532, 533, 535. PICKL 1966, 377-378. In addition, see also MAYER 1924-1928, I/2. 216-232 (trade in general in Wiener Neustadt), 176 (trade guild), 209, 378 (Werdl); Scheutz et al (Hgg.) 1997, 45 (12 March 1439 "Kramer ordnung"), 76-77 (24 May 1470 - "Hanntvest und freyhait der Kramer")

${ }^{44}$ Leonhard Gerolt, the father of Dorothea Gerolt, died in 1474 . His gravestone was observed and fortunately published by J. V. Sonntag, as it has since perished. SonNTAG 1844,42

45 EIRICH 1971, 278 (Gerolt).

${ }^{46}$ This is attested to by the several landed properties, noted by Jakob Gerolt in his land register: Graz, StLA, A. Knittelfeld Stadt K. 77. H. 350 (Urbar 1489), fol. 63r ("wisen in der Glein" - Andre Gerolt), fol. 96r ("anger gelegen in der Glein" - Bernhard Gerolt), fol. 126r ("wisen gelegen ob der Haffengasse" - Bernhard Gerolt as well as Valentin Gerolt), fol. 133r ("wisen gelegen under dem Czehentstadel" - Valentin Gerolt as well as Andre Gerolt), fol. 137r ("Gotzhaws zu Lind wisen die ietz mein brueder hat an des Czehentstadler grund" - Valentin Gerolt), fol. 144v ("garten und stadel die dann ligen neben an sein haws" - Valentin Gerolt), fol. 145r ("hofstat hab ich kchauft von mein lieben brüeder" - Valentin Gerolt and from 1491 onwards Jakob Gerolt), fol. 145v ("zu dem pharrhoff die anderen tzwo dem oberen haws das ietz meines brueder ist" - Valentin Gerolt), fol. 166r ("am Wiesen gelegen ob den oberem Pruckhchtor ob der Haffengassen" - Andre Gerolt). Graz, UBG, MS 74, fol. 360v ("der Haffenngassen ain wisen so ytzt fraw Veronica des Andre Gerolts hausfraw innenhat"). Diözesanarchiv Graz Seckau, Bistumsurkunden, II-164a (19 August 1489 , charter about a family foundation in the parish church of Knittelfeld), the document was used from www.monasterium.net (last accessed: 20.03.2018), fol. 2r ("sechs agkher freyes aygen gelegen bey der stat Knutelfeldt, die funff agkher ligen vnder dem griess im Lontschach feldt [...] der sechst agkher gelegen bey Sand Johanns im Veld raint" Gerolt family heritage).

${ }^{47}$ Graz, StLA, A. Knittelfeld Stadt K. 77. H. 350 (Urbar 1489), fol. 53r, fol. 138r, fol. 139v, fol. 146r. His wife's name is known from the missal of Jakob Gerolt: "[...] Haffenngassen ain wisen so ytzt fraw Veronica des Andre Gerolts hausfraw hat [...]". Graz, UBG, MS 74, fol. 360r.

${ }^{48}$ Relevant research by a few scholars suggest there were elections in every second year in Knittelfeld. SONNTAG 1844 41; HAMmer 1959, 206; POPELKA 1951-1963, 338-339.

49 "Valtein Gerolt, burger zu Judenburg": Diözesanarchiv Graz Seckau, Bistumsurkunden, I-72a (24 July 1492, he sold his ploughland to the bishop of Seckau), the document was used from www.monasterium.net (last accessed: 20.03.2018). Already as a burgher of Judenburg, he sold one of his immovable properties to his brother-in-law, Hanns Anngrer, a member of a butcher's family. Graz, StLA AUR 9598 (1497). POPELKA 1951-1963, II. 337.

50 Mell 1896, 26. PoPelka 1951-1963, I. 692. He might have been commuting between Judenburg and his original hometown; at least in 1503 he had a vice-judge called Hans Stahel ("verweser anstat Valenntin Gerolts statsrichterambts zu Judenburg") Graz, StLA, AUR 4 May 1503 (see also POPELKA 1951-1963, I. 496). He was last mentioned in the town sources of Judenburg in 1504: Graz, StLA, AUR 14 January 1504 (see also POPELKA 1951-1963, II. 33).

${ }^{51}$ In the last will written in 1511 , Paul Stettner from Wiener Neustadt mentioned his debts to his brother-in-law, Valentin Gerolt. WNStA, Ratsbuch II, 361 (see also PICKL 1966 381). However, it is not clear whether this Valentin Gerolt is the same or was already a member of the next generation, which is more probable (especially in light of later information about his appearing in Memmingen, see below).

52 According to Othmar Pickl, he died in 1528. PICKL 1966,25

53 Graz, StLA, A. Knittelfeld Stadt K. 77. H. 350 (Urbar 1489), fol. 98r ("ain akcher ym Lantschach veld gelegen ob des Haczen hof raint mit ainer leng an meiner swester Anna Geroltin akcher"), fol. 130r ("ain stukch akcher ym Lontschachfeld raint mit der leng an des Gotzhaws Sand Margareten neben der Anna Geroltin meiner swester akcher").

${ }^{54}$ In 1495, according to Raimund Eirich: EIRICH 1971, 202 (Funk family tree); also in HarL 1954, 151. Nevertheless, according to Othmar Pickl it happened in 1496: PICKL 1966, 25. For the coat of arms of the members of the Funk family: ANKWICZ-KLEEHOVEN 1955, 51.

55 According to Elfriede von Harl, Dorothea Gerolt's sister Elisabeth married a certain Rembold Funk (HARL 1954 152). Without archival reference, this information could not be checked; furthermore, it was not possible to clarify which of the several Funk family members named Rembold became her husband (see Fig. 16). 
${ }^{56}$ The genealogy of the family was put together by two scholars: PICKL 1966, 24-26 (Stammtafel der Familie Funk); EIRICH 1971, 202-203 (Abb. 14). The family moved from Schwäbisch Gmünd to Memmingen (two brothers, Andreas and Johann Funk), but it was the uncle, Wilhelm Funk, who started trading with Styria. Another brother, Kaspar Funk, married a daughter of a trading family in Nördlingen and was also involved in long-distance trade. PICKL 1966, 23-34.

${ }^{57}$ HARL 1954, 151.

${ }^{58} \mathrm{He}$ appeared in the tax list of the Golden Lion's company first in 1483 and then regularly from 1487. Around this time, he married Anna Gwerlich. In 1506 he became a town official in Memmingen. Afterwards he sat on the council between 1507-1513 and was the mayor in 1512/1513. PICKL 1966, 25-26, 30-31; PICKL 1967; EIRICH 1971, 202.

${ }^{59} \mathrm{He}$ bought a house from Peter Swab in 1506 . EIRICH 1971, 189-203 (Funk Gesellschaft).

${ }^{60}$ His business account books are extant: WNStA, Bde 883-887 (five manuscripts). Published in: PICKL 1966.

${ }^{61}$ Alexius Funk moved from Memmingen to Wiener Neustadt in the 1490s and expanded the family business operations to Hungary as well. First he dealt in the cloth trade (Tuchhandel), but later he increased the array of goods and also extended the trading area from Breslau to Venice. In Wiener Neustadt he bought several houses between 1497 and 1514 (he lived by the fish market - today Hauptplatz 9, next to doctor Georg Taler - PickL 1966, 33). He also had a "Brandstatt" in Neunkirchnerstrasse between 1507 and 1512 (PICKL 1966, 48), in the street where Dorothea Gerolt's second husband, the widower Geinperger, lived. He was councillor several times and also mayor in the town. MAYER 1924-1928, II/1. 62; ANKWICZ-KleEHOVEN 1955, 4546; PICKL 1966, 45-53; PICKL 1967; EIRICH 1971, 189-203; Bastl 1984; Niemetz 1985; Müller 2009.

62 PiCKL 1966, 45. Hyppolit Stainer/Steiner also had family ties to the Gerolts of Knittelfeld (as members of the Hammerherrengeschlecht). He and Hans Werdl the Younger were among the heirs of Margaretha Gerolt, the widow of Leonhard Gerolt of Knittelfeld. WNStA, Gewährbuch I, fol. 174r (p424).

${ }^{63}$ It is presently preserved in Schaffhausen, in the Museum zu Allerheiligen. Schaffhausen, MA, inv. no. A637. See also ANKWICZ-KLEEHOVEN 1955; PICKL 1966, 128; EIRICH 1971, 320-321 (Abb. 18). On the painter Bernhard Strigel in general: Отто 1964. Nevertheless, it is interesting that Anna Gerolt did not use the family house mark but a different coat of arms with a donkey. Discovering the reasons would require more research. Hans (II) Funk also had a devotional diptych, which today is preserved in the Alte Pinakothek in Münich: MülLER 2009, 3 (Abb. 4).

${ }^{64}$ EIRICH 1971, 189-203 (Funk Gesellschaft).

${ }^{65}$ WNStA, Bd 885, 408. PICKL 1966, 244.

${ }^{66}$ EIRICH 1971, 278 (Gerolt); EIRICH 1981, 202 (Funk family tree). This Elisabeth must have belonged to a younger generation than Dorothea Gerolt. As mentioned above, Dorothea Gerolt's sister Elisabeth might have been married to a Rembold Funk (HaRL 1954, 152). Further research is needed to clarify whether there is confusion in the secondary literature, or the older and younger Elisabeths indeed both married Rembolds from different generations of the Funk family.

67 So far, no other hint has been found concerning which brother might be the father. We might speculate that it was
Valentin Gerolt, who moved from Knittelfeld to Judenburg (a more influential trading centre along the "iron road") and continued trading both in iron and most probably in leather, too (see notes 39 and 49).

${ }^{68}$ EIRICH 1971, 278 (Gerolt).

${ }^{69}$ Graz, UBG, MS 74 (Alte Sign. 37/18). EICHLER 1906, 53-69. See also Hans ZotTeR's description online: http:// sosa2.uni-graz.at/sosa/katalog/katalogisate/74.html (last accessed: 08.03.2018).

70 "[...] et ego Jacobus Jeroldus [sic!] artium jurisque pontificij doctor, et prefate ecclesie pastor in fidem omnium premissorum scripsi et me subscripsi, laus Deo." Graz, UBG, MS 74, fol. $2 \mathrm{v}$.

${ }^{71}$ Graz, UBG, MS 74, fol. 3r-8v.

72 Graz, UBG, MS 74, fol. 359r-360v.

${ }^{73}$ Graz, UBG, MS 74, fol. 2v: "[...] omnium defunctorum ex familia Ierolda [sic!] [...]"; fol. 4r (no. 2): "Gregorij papae: [...] commemoracio fiat familie Gerolde cum vigilys mortuorum et laudibus deinde dicte familie Geroldorum sepulchri visitatio ante altare sancti Jacobi apostoli maioris ac deinde fiat per ecclesiam ipsam circuitus et ante karnarium vbi defunctorum ossa requiescunt [...]"; fol. 4v (no. 3): "secunda feria post octauas pasce - anniuersarius Leonardi Geroldi"; fol. 6r: "Marie Magdalene - memoria familie Gerolde [...]"; fol. 6v (no. 12): "Decollacionem Sancti Ioannis Baptiste - anniuersarius Margarethe Ierolde [sic!] [...]"; fol. 7v: "Symonis et Iude apostolorum - officium de mane super altare fundatorum Ieroldorum familie [...]"; fol. 8v: "Nycolai episcopi - de familia Gerolde mortuorum quarta memoria [...]"; fol. 359r (no. 2, no. 3); fol. 359v (no. 6); fol. 360r (no. 9); fol. 360v (no. 12, no. 16).

${ }^{74}$ Graz, UBG, MS 74, fol. 1r ("Hoc missale dedit sanctis ad sacra ministris Geroldus: templi qui pater huis [sic!] erat"). His patron saint, Jacob, is depicted instead of the family house mark in the coat of arms at his knees.

75 SonNTAG 1844, 30 (Muerer), 42-43 (Gerold). HAMmER 1959, 406-411.

${ }^{76}$ Unfortunately, these Gerolt gravestones have not survived. Their texts and the family house mark were documented in: SonNTAG 1844, 42 ("hie ist begraben der ehrbar mann Lienhard Gerold, stifter des gegenwartigen altars, ewigen mess, den Gott gnädig sey, ist gestorben am mondtage vor St Jörgentag 1474"), 70-71 (Jakob Gerolt). Nevertheless, two gravestones belonging to their kin, the Muerers, who founded the chapel of St Catherine in the parish, can still be seen in the church. On that gravestone it reads: "Hie sey begraben Peter Mürer Anna sein hausfraw Valtrin Joachim Jorg / vnd Godiaer [sic!] dy Mürar ir bayder / sun stiffter sand Kathrein cappelln vns Got allen genadig sey 1476." It is not known what happened to the Gerolt gravestones after they were documented in 1844. However, in the early twentieth century, when most medieval parts of the parish church were still visible (it was destroyed in World War II), they were no longer seen in the church (according to the information of a few elderly eyewitnesses). Here, special thanks should be expressed to Hans Rinofner for his help during our visit to Knittelfeld. See also RinOFner 2006.

77 "Ich Jacob Gerolt der siben freyn khünsten maister, und geistlicher rechten lerer auch des wirdigen gotzhaws sand Johanns gotztauffers pharrkirchen inn der stat Khnutelfeld pharrer thue [...] das Anndre Valentin Berenhardin, all dreÿ burger daselbs die Gerolten, vnd Dorothea Elizabeth, Anna, 
alle meine liebe geswistriget, mitsambt mir, auf weylent Leonharten Gerolt burger alhie zu Khnutelfeld vnd Margarethen seiner eelichen hausfrawn, vnnser obgemelten geswistriget lieben vater vnd müeter seligen ordenung, geschäft vnnd leczten willen zuvolbringen [...] dem heiligen zwelifpoten sand Jacob dem merern, sand Cristoff dem heiligen martrer, den heyligen herren vnd peichtigern sand Leonart vnd Wolfgang vnd allen heyligen zu eeren [...] loblichen altar bey den pheyller, gegen dem predigstuel vber, durch sy von neu erhebt vnd gepawt, [...] vmb solh stifft [...]." Diözesanarchiv Graz Seckau, Pfarrurkunden, II-164a (19 August 1489), the document was used from www.monasterium.net (last accessed: 20.03.2018). Graz, StLA, A. Knittelfeld Stadt K. 77. H. 341 (Mss by Paul Dedic 1943), p2. The foundation charter was later translated into German and was preserved among the archival material of the town: Graz, StLA, A. Knittelfeld Stadt K. 82. H. 382, Stiftungsurkunde 1490.

${ }^{78}$ HAMMER 1959, 419-421. The first members written into the confraternity book were: Andre Gerolt and his wife; the old parish priest (called "Lienhart") and the new one (Jakob Gerolt), who began his tenure during Lent of 1479, after he returned from Vienna; Leonhard Gerolt; the members of several other families of craftsmen in Knittelfeld. Graz, StLA, Knittelfeld Stadt K. 84. H. 406, fol. 2r ("Andre Geröllt" 1478-1516, "Andre Gerölltin" 1480-1505); fol. 14v ("Werhardin Gerolt" 1489-1494); fol. 104r ("Jacob Gerolt pharrer hie zu Knütelfeldt" 1479-1484); fol. 122r ("Linhardt Gerolltin" 1478-1480); fol. 228r ("Valthan Gerold" 1481-1490).

${ }^{79}$ Graz, StLA, Knittelfeld Stadt K. 84. H. 406, cover and fol. $1 \mathrm{v}$. See also note 42.

${ }^{80}$ Not only Stephan Geinperger and Hans Glockengiesser, but other relatives (Alexius Funk) and possible friends (Hans and Wolfgang Roll, whose graves neighboured the Geinpergers) were members of the Corpus Christi confraternity in Wiener Neustadt. Hans Roll's and Hans Glockengiesser's names were already on the list written in 1477 . Stephan Geinperger must have been added some time after his move to Wiener Neustadt in 1489. Alexius Funk and his wife, Margaretha, were added in 1508 and Wolfgang Roll and his wife in 1511. WNStA, Scrin. CXIX, Nr. 45, fol. 19. See also DreXler 1955, 89 (Roll), 93 (Geinperger and Funk), Anhang (xviii-xix).

${ }^{81}$ A certain Hans Gerolt (written as Herolt) bought a house in the "mynnerbrüder virteil zunagst weilent Eberhartten Meischner haws am egk vnd gegen Casparn Stainmetzen haws vber" (6 June 1449). WNStA, Gewährbuch I, fol. 33r (p143). This house was sold in 1471 for fifty-eight good Hungarian golden ducats on condition that, until the money was received, Hans Gerolt could live in the "hindern zymmer zinnsfrey" (10 May 1971). WNStA, Satzbuch A, fol. 194r (p249). Two years later a certain "Hans Gerolt purger von Knittelfeld" and his wife, Katherina, bought a house in another quarter, "ain hawsz hie gelegen in vnser frawen virtel annechst des Fridrichen Grym ainhalb vnd anderhalb des caplans auf Sant Achatzen altar hawser sint vj d(enarii) zu gruntrecht" (1 October 1473). WNStA, Satzbuch A, fol. 3r (p28).

82 WNStA, Ratsbuch I, 532, 533, 535. See also PICKL 1966, 377-378.

${ }^{83}$ The Werdls had a house in the outer Ungergasse: "Hanns Werdl der jung [...] eins halben hawss hie gelegen in der aussern vngerstrass zwischen Micheln Ledrer vnd Linhartten Schilher hewsern sint das gantz haws xij d(enarii) gruntrecht $[. .$.$] von Hannsen Werdl seinem vatter seligen erblich$ angeuallen ist [...]" (12 June 1478). WNStA, Gewährbuch I, fol. 159r (p394). Hans Werdl the Elder inherited it together with his wife, Katherina, from his mother, Elisabeth (25 April 1458). WNStA, Satzbuch A, fol. 21r (p64). It was also mentioned in the last will of Hans Werdl the Younger who left it to his stepbrother, Georg Lustock, and his stepsisters, Anna, Barbara and Magdalena: "Item mein haws gelegen in der vngerstrass zwischen Micheln Plancken vnd weilent Clausen Sneider hewsern [...]." (30 December 1483). WNStA, Ratsbuch II, fol. 252r (p225).

${ }^{84}$ In the already mentioned last will, Hans Werdl the Younger left three vineyards ("einer gelegen zu Welestorf im Hayperg, die andern zwen zu Pfafsteten") to his niece's children, born to Hans Glockengiesser: WNStA, Ratsbuch II, fol. 252r (p225). In 1478 another entry in the town book confirms that Wolfgang Lustock (also mentioned in the last will) was the stepbrother of Hans Werdl the Younger: WNStA, Ratsbuch II, fol. 570r (p539). Wolfgang also left a will (14 February 1475) and donated the new panel of the altar of St Dorothea, which belonged to the merchants guild: WNStA, Ratsbuch II, fol. 233r-234v (MAESTRO 1995, 126; SKVARICS 2000, 241). See also SKVARICS 2000 , $111-112$

${ }^{85}$ WNStA, Gewährbuch, fol. 213r (p500): "Maister Stephan Geinperger lerer in der ertzney etc. hie, Dorothea uxor, sind nutz und gewer komen ain egkhawss hie gelegen in der newnkircherstrass, neben des hochwirdigen fursten vnd herren, herrn Vrban erwelter vnd bestetter zu bischouen zu Erlach, vnd gegen weilent Jörgen Hafendler seligen hawse vber, sint dasselb hawse xxj d gruntrecht et non plus, das der benanten Dorothea fur das gemechte so ir irerer hawsswirt maister Hanns Glockengiesser seliger nach laut irs gemechtsbrief getan [...] darumb dieselb fraw Dorothea den obgenanten master Stephan Geinperger auss sonnderer liebe vnd trew zu ir nutz vnd gewer hat setzen vnd schreiben lassen." (1 December 1489).

${ }^{86}$ WNStA, Satzbuch A, fol. 219r (p297): "Maister Stephan Geinperger et hic, Dorothea uxor, haben versatzt ir egkhawse hie gelegen in der newnkircherstrass neben des hochwirden fursten vnd herren herrn Vrban erwelten vnd bestetten zu bischouen zu Erlach vnd gegen weilent Jorgen Hafendler seligen haws vber sint $\mathrm{xxj} d$ gruntrecht et non plus, vmb zwayhundert gulden vngrisch, Magdalen Cristoffen vnd Barbara den vnuogtpern kindern so weilent maister Hanns Glockengiesser seliger bey der benanten Dorothea auch seiner hausfraw hinder sein verlassen hat, die an dieselben kindern nach lautt ihres vermelten vatters seligen heyrattbriefs vnd darauf innhalt des spruchbriefs von burgermaister vnd ratte hie auszgangen vnd ir erben komen sind dieselb zwayhundert gulden sol die egenant Dorothea Geinpergerin ir lebttege innhaben nutzen vnd niessen vnd nach irem abgang auf die obgenanten drew kinder gefallen wie versteet." (1 December 1489).

${ }^{87}$ MAYER 1924-1928, I/2. 209 (note 2). However, no such direct relationship is stated in the source he refers to: WNStA, Ratsbuch II, fol. 252r (p225) - 3 December 1483 The testator only mentions Glockengiesser's children and a vineyard in Höflein, half of which was owned by Hans Werdl, and the other half by Hans Glockengiesser. 
${ }^{88}$ MAYER 1924-1928, I/2. 208-210. For the relevant summaries of the related documents from the urban archives of Wiener Neustadt: MAYER 1886, 82-88 (Nos. 3872, 3874, 3882, 3896, 3903, 3923, 3927, 3943, 3962).

${ }^{89}$ WNStA, Ratsbuch II, fol. 140r (p36-37): "Dem ersamen hochgelerten maister Hannsen Glogkengiesser decretorum licenciat(us) vnsern turn genant Pewsching gelegen bey Newnkirchen mit aller sein zugehörung, nichts darinnen ausgenomen noch hindan gesaczt sunder alles inbeslossen zu ain rechten vnd redlichen leibgäding auf sein ains leib vnd lebteg in leibgädingsweis vmb iijc vngerisch vnd ducaten guldein gut vnd gerecht in gold vnd wag [...]." MAYER 19241928, I/2. 45, 53-54 (a related council meeting in 1482).

90 WNStA, Gewährbuch I, fol. 139v (p355): "Maister Hanns Glockengiesser, et hic licenciat(us) in geistlichen rechten, ist nutz vnd gewer komen ainns halben hawss gantzes hie gelegen in der inner wiennerstrass zwischen des spitalmaister vnd N des Herreser hewsern." (27 August 1473). The previous owner was "Sigmund Schiesser der Schuster". WNStA, Gewährbuch I, fol. 127v (p331). He very soon sold it to Peter Lepharzöder and his wife, Elisabeth (15 July 1474): WNStA, Gewährbuch I, fol. 114v (p365).

${ }^{91} \mathrm{He}$ bought it from Walthesar Egkenperger from Graz in 1476, who had previously bought it in 1471 for a thousand Hungarian ducats. For more on him: NASCHENWENG 2016, 231-237; SPROGER 2019, 54-62 (on his donations and gravestone), 69-79 (on his social standing). This sum in itself suggests the dimensions and importance of the given plot (and its buildings). The previous noble owners were "Maria herrn Sebastians grafen zu Ortemburg vnd Barbara herrn Hainreichs Nothaft gemaheln", who were sisters and inherited the house from their mother, "weilent fraw Scolastica, herrn Johannsen freyherren zu Newnburg auf dem Yn vnd zu Rorbach irs vattern seligen wittibe" (5 April 1471). WNStA, Gewährbuch I, fol. 127v (p331 - two entries one after the other). For Johann, Freiherr zu Neuburg am Inn und Rohrbach (and Scholastika von Weißpriach): HeINIG 1997, I. $62,107,116,118,248,287-290$. Hans Glockengiesser, upon buying this corner house, became the neighbour of "Hans Süssenhaimer" (6 February 1476). WNStA, Gewährbuch I, fol. 150r (p376).

92 "Maister Hanns Glockengiesser licenciat in geistlichen rechten ist nutz vnd gewer komen ains hawss hie gelegen in vnser frawn virtail in der newengassen, zwischen Jorgen Maler vnd Thoman Grünawer hewsern, sint xij d(enarii) gruntrecht vnd ains hauss hinden daran gelegen zwischen Wentzla Zingiesser vnd Micheln Ryemer hewsern vnd stosset an Müschl des Juden hoff sint vj d(enarii) [...] mit kauff von burgermaister vnd ratt [...]." (12 November 1479). WNStA, Gewährbuch I, fol. 167v (p411).

${ }^{93}$ This vineyard (see also notes 84 and 87 ) is mentioned in the last will of Hans Werdl the Younger: "Item mein weingartl gelegen zu Höflein, den halben der Glokengiesser hat, vnd halber mein ist [...]" (30 December 1483). WNStA, Ratsbuch II, fol. 252r (p225).

${ }^{94}$ WNStA, Ratsbuch II, fol. 143v (p43), fol. 144r-v (p4445).

${ }^{95}$ WNStA, Ratsbuch II, fol. 9r (p5): "Das sind die Genandten" - in the second column third from the bottom - "maister Hanns Glockengiesser". For the significant changes in the urban council initiated by Emperor Frederick III, see later note 106.
${ }^{96}$ Rathschlag, 2 Februar 1485: "Augustin Pottenstainer, master Hannß Glokhengießer, und Jeronimuß Schoßl haben als anwält der müns so durch die kais(erliche) mai(estät) hie zu münsen geschafft ist". WNStA, Schrin. E 159/5. BoEHEIM 1886, 32 (no. 3361). Mayer 1924-1928, I/2. 209, 235.

97 WNStA, Ratsbuch II, fol. 28r (p23) - 1484; fol. 28v (p24) - 1485; fol. 29r (p25) - 1486.

98 WNStA, Ratsbuch II, fol. 29v (p26) - 1488.

${ }^{99}$ The altar of St Andrew was founded by the councillor Friedrich Sechsperger and his wife sometime after the mid-fifteenth century. SkVARICs 2000, 115-117. For its present location: Niemetz (Hg.) 20032. The mass foundation was supported with income from the mills that were taken over by Hans Glockengiesser: "als vormals weilnnt Fridreich Sechsperger vnnser mitburger vnd Anna sein hausfraw seligen ir beider mule gelegen zu Ekhendorff mit aller irer zugehörung dauon man jerlich dint dem edeln herren herren Hannsen von Künigsperg vnd sinen erben iiij tal(enta) $\mathrm{d}$ (enariorum) zu grundtrecht [...] zu einer ewigen messe vnd stiffte in vnnser lieben frawen pfarrkirchen hie zu der Newenstat auf sant Anndres altar in der abseitten gegen dem pfarrhof vber gelegen geordnet [...].” (22 April 1479). WNStA, Ratsbuch II, fol. 143v (p43). For Alexius Funk's order for his burial next to his brother-in-law (19 March 1515): WNStA, Ratsbuch II, fol. 353v (see also PICKL 1966, 47, 393). For Hyppolit Steiner's gravestone: RöHRIG (Hg.) 1979, 332-333 (no. 29); KoHN 1998, 107-108 (no. 160).

100 MAYER 1924-1928, I/2. 168, 209.

${ }^{101}$ MAYER 1924-1928, I/2. 209 (note 4).

$102 \mathrm{He}$ is named as "hochgelerter, maister Hannsen Glogkengiesser, decretorum licentiatus" in the document from 1471 (28 May). WNStA, Ratsbuch II, fol. 140r (p36-37). Otherwise, he usually referred to himself as master "Hanns Glockengiesser, licenciat in den geistlichen rechten vnd burger zu der Newenstat". For example, WNStA, Ratsbuch II, fol. 144r (p44) - 22 April 1479.

${ }^{103}$ Heinig 1997, I. 138-139, 807. Also mentioned: WACHAUF 1972, 33, no. 62 (with other source references).

${ }^{104}$ MAYer 1924-1928, I/2. 209. Concerning this problem, Paul-Joachim Heinig (Heinig 1997, I. 138-139, 807) referred to the works of Helmut Wachauf (WACHAUF 1972 33, no. 62) and Peter Moraw (Moraw 1986, 134). To complicate matters, there is also a famous Hans Glockengiesser in Judenburg, who moved there sometime in the 1440s and died there in 1471 (PopelKA 1951-1963, II. 337-338). This person's son could also be a possibility thanks to the strong trade connections between Judenburg and Wiener Neustadt. However, nothing is known about his studies, and he sometimes appears with an additional name "Mitter", while the Hans Glockengiesser in Wiener Neustadt did not. Nevertheless, Paul-Joachim Heinig accepted the identification made by Helmut Wachauf, who also mentioned that the Hans Glockengiesser of Nuremberg died in 1488, which corresponds to the date of death of Hans Glockengiesser in Wiener Neustadt. In the given year, he was still listed as a member of the outer council of Wiener Neustadt, but a comment by his name notes that he was deceased. WNStA Ratsbuch II, fol. 29v (p26). On the other hand, there was a certain "Johannes Gloggengiesser de Sancto Gallo" who paid four groschen when he matriculated at the university of Vienna in 1451 (14 April); Vienna, UAW, Matrikel Wien 2, 2 (Natio Renensium, line 17). In that case, however, we 
only find him studying in the faculty of arts, and there is no further information on his legal studies. Furthermore, given the intensive contact between Nuremberg and Wiener Neustadt during the reign of Emperor Frederick III, the place of origin posited by Paul-Joachim Heinig might be accepted. This fact is further strengthened by other evidence discussed later in this article.

105 About his birth and studies: WACHAUF 1972, 33, no. 62. About his family: GRIEB 2007, 480-481. About his university studies: Padua, UPa, AGA II/2, 125 (no. 332 - 2 June 1464): "dominus Iohannes Glockengiesser de Nuremberga scolaris iuris canonici". See also RAG Datenbank: http://www.ragonline.org/de/datenbank (last accessed: 25.07.2018). He studied together with a member of the Funk family: "magister Henricus Funch (de Alamania) de Gamundia decretorum doctor". Padua, UPa, AGA II/2, 177 (no. 450 - 28 June 1465): "In palatio episcopalis super salla: licentia concessa domino Iohani Gluckengiszer de Nuremberga quod possit quandoque publicum examen in iuris canonici subire, qui fuit examinatus et approbatus nemine disentiente sub promotionis suis [...]". We have already seen some elements of the kin relationships between the Funks and the Gerolts. In addition, now it seems that because of their common university studies in Padua, Hans Glockengiesser of Nuremberg might have remained in closer contact with a member of the Funk family

${ }^{106}$ According to the text, it was decided by Frederick III that the council of Wiener Neustadt should have thirtyseven members, out of which thirteen sat in the inner council together with the mayor and the judge, while the remaining twenty-four should be named as "Genannt", and it was the gremium from which the members of the inner council were chosen each year. If somebody among the "Genannten" died, the mayor, together with the members of the inner council, decided upon the installation of a new member in order to maintain the required number of people in the urban government. In addition, the final choice of officeholders was confirmed by the emperor. WNStA, Ratsbuch II, fol. 8r (p3). On the rules of 1468 concerning the council election, see: SCHOber 1885, 225-226; MAYer 1924-1928, I/2. 145-153, especially 146-148; GERHARTL 1978, 161-162; Hofmann 2010, 24-25, 31-32. It was modified later in 1604: Rist 2005/2007, 137

${ }^{107}$ For 5 August 1468: Landesregierungsarchiv Innsbruck, Hs. 117, fol. 30v. Quoted in: KNolle 1965, 115 (note 45). For 1471: Hessischen Staatsarchiv, Darmstadt, Sign. E 9 Nr. 2/1: Kammergerichtsordnung. Quoted in: BATTENBERG 1978, 58

108 WNStA, Ratsbuch II, fol. 140r (p36-37): "Versatzung des turn Pewsching in leibgädingsweis maister Hannsen Glogkengiesser". According to Josef Mayer, he also appeared as the "Pfleger" of a certain land (most probably the castle of Pitten) in the environs of Wiener Neustadt in 1473. MAYER 1924-1928, I/2. 110 ("Pfleger zu Pütten").

109 WNStA, Scrin. CXIX, Nr. 45, fol. 19. See also DreXLER 1955, 94. Elfriede Drexler discusses the members not as they were listed, but in several groups according to their different social standings, although the order in which they were listed also seems to have relevance. The first name was Emperor Frederick III, followed by Johann Siebenhirter, the first master of the Order of Saint George, founded by the emperor in 1469. Next was the marshal of the house- hold (Hofmarschall), Georg Fuchs von Fuchsberg, and nine other significant people (Ritter Christoph von Rappach, Ritter Wilhelm von Aichberg, Ritter Leopold Wehinger, Ritter Florian Winkler, Ritter Niklas Bundäckh, Master Hans Glockengiesser, Hanns von Wilfelstorf, Ritter Veit von der Alben and Burkhard von Waldsburg) were listed before Procop Zinner, the confraternity master himself.

110 If we accept the identification of Dorothea's first husband as Hans Glockengiesser of Nuremberg, then Dorothea must have been his second wife. In Nuremberg he married Dorothea Huber. For this first marriage, see WACHAUF 1972 33, no. 62 (with reference to sources in the Nuremberg Town Archives that we were not able to check). For the members of the Glockengiesser family, see also: GRIEB 2007, 480-481.

${ }^{111}$ This date (year) corresponds to the relevant entry in the Wiener Neustadt Ratsbuch already mentioned above: WNStA, Ratsbuch II, fol. 29v (p26).

112 According to the entries of Sebolt Schreyer, the church master of St Sebald (1487-1503), the liturgy was ordered in the period between 28 May and 17 September 1488. BURGER (Hg.) 1961, 117, line 3703: "hr. Hs. Glockengießer, doctor". At the same time there is an exact date (6 September 1488), when his name was written in the Totengeläutbuch of the other parish church of St Lawrence: "Item doctor Glockengiesser eodem die [am sambstag vor unser lieben frawen gepurtt 1488]." BURGER (Hg.) 1967, 134, line 2543. For the burial places of the father and the brother: GRIEB 2007, 479 (brother), 480 (father).

${ }^{113}$ In this respect, the case of Alexius Funk is relevant. Funk came from Memmingen but lived in Wiener Neustadt. However, he was buried in Memmingen (although he stipulated in his will that he should be buried in Wiener Neustadt), since he died there while visiting his hometown. PICKL 1966, 46-47; EIRIK 1971, 192-193. Nevertheless, according to his wishes, an epitaph was indeed placed in the parish church of Our Lady in Wiener Neustadt in his memory. ANKWICZ-KLEEHOVEN 1955, 49-50.

${ }^{114}$ If the Nuremberg origin is correct and Dorothea Gerolt was Hans Glockengiesser's second wife, another hypothesis can also be proposed in connection with the epitaph in question, namely that among the children depicted on the female side, some might have been stepchildren to Dorothea. Otherwise, if Dorothea was married to Glockengiesser around 1480, and he died in 1488, all seven children must have been born within these years. However, it is also known that in 1462, a funeral was held for the daughter of a certain Hans Glockengiesser in the church of St Lawrence in Nuremberg (the family parish church - GRIEB 2007, 480). "Item merer des Hans Glockengiesserß tochter" (15 October 1462), BuRGER (Hg.) 1967, 24, line 577. The question remains whether this child was from the first marriage of the Hans Glockengiesser who then moved to Wiener Neustadt.

${ }^{115}$ For his person: MAYER 1924-1928, I/2. 282. See also later, note 168 and 172

116 Vienna, UAW, AFA III/2, 7 (Determinatio); Vienna, UAW, AFA III/2, 37 (Inceptio). Tuisl 2014, 299-300. See also RAG Datenbank: http://www.rag-online.org/de/datenbank (last accessed: 25.07.2018).

117 Lectures: Vienna, UAW, AFA III/2, 52 (1477 I), 58 (1478 I), 65 (1479 I), 72 (1480 I), 79 (1481 I), 85 (1482 I), 90 (1483 I), 96 (1485 I), 99 (1486 I). Examinations: Vien- 
na, UAW, AFA III/2, 84 (1 June 1482, Stephanus Genperger ex Patavia, mag., Examinator der Sächsischen Nation), 92 (12 March 1484, Steffanus de Patavia, mag., Examinator der Rheinischen Nation), 97 (3 January 1485, Steffanus Geyperger ex Patavia, mag., Temptator), 100 (10 March 1487, Stephanus de Patavia, mag., Examinator der Rheinischen Nation). For further information on Johannes Tichtel, see: https://www.geschichtewiki.wien.gv.at/Johannes_Tichtel

(last accessed: 28.12.2018), with further references.

${ }^{118}$ In 1480 he paid twenty-one denars for his inscription; later in 1486 he paid one florin before his determination (27 September) and also three groschen for his intitulatio. In 1488 he asked to take the examination for which he could receive the title doctor medicus (28 February), and finally he was promoted by the vice-chancellor (18 March) and inducted into the consilium facultatis (30 October). Vienna, UAW, AFM II, 218 (1480); Vienna, UAW, AFM II, 211 (1486); 209 (1488); Vienna, UAW, AFM II, 187 (1486); Vienna, UAW, AFM II, 192-193 (1488); Vienna, UAW, AFM III, 306. TUISL 2014, 299-300. See also RAG Datenbank: http://www.rag-online.org/de/datenbank (last accessed: 25.07.2018)

${ }^{119}$ Vienna, UAW, AFM III, 1. TuISL 2014, 300; HoRN 2003, 164. See also: Horn 2001.

${ }^{120}$ For a short description of his university years and later career, see also: Müller 1993; Müller 1994, 440-441.

${ }^{121}$ The book itself was prepared in 1422. Passau, PStA, II.A. 25 (Alte Sign. B23 H28), fol. 3r. However, the guild was already mentioned in a document in 1306. EICHHORN 1995, 91; Boshof et al (Hgg.) 2003², 107. A certain Peter Gailsperger appeared in the sources in the 1440s (quoted in: ERHARD 1862-1864, I. 175), but it is hard to decide whether it is a distorted form of the family name or whether this Phleger of the Holy Spirit belonged to another family.

${ }^{122}$ Passau, PStA, II.A.25, fol. 5v (20 February 1448); fol. $6 \mathrm{v}$ (27 June 1441). We also come across his name in other town documents, for example, in the "Verzeichnis der einnahmen und ausgeben für die passauischen söldner": Passau, PStA, II.A.32 (1445), II.A.33 (1447).

${ }^{123}$ Chmel 1853, 226-227 (Kammerbuch IV: 867-870 Revers der Salzfertiger zu Hallein, XVIII. 27 Juni 1441).

${ }^{124}$ Hainisch-Woisetschläger (Dehio) 1977, 88 (Geinberg).

125 Generally, see: Maier 1965; Palme 1983; Rausch (Hg.) 1988; Loibl 1995; Wurster et al (Hgg.) 1995, 51-52; BOSHOF et al (Hgg.) 20032, 107-111. For a map of the environs: Boshof et al (Hgg.) 20032, 102 (although Geinperg itself is not indicated). On the region in the context of the other East Central European salt mining areas: DRASKÓCZY 2018, 9-17. On the "Unser Lieben Frau Salzfertiger- und Schiffleut-Zech" (mainly on its history in the sixteenth and seventeenth centuries, but also its sources): EICHHORN 1995.

${ }^{126}$ As a research idea, the possibility was raised that during his time at university in Vienna, Geinperger practiced the art of fencing, in which shorter swords were also used, and that might have inspired his heraldic "choice". The first fencing school in Vienna is documented from 1468. The first German fencing manuals were actually written by burghers (examples in: JaqueT-Verelst-DaWson (eds.) 2016), such as the one by the fencing master Hans Talhoffer in 1467. Bayerische Staatsbibliothek in Munich, Cod. icon 394a available online: https://www.digitale-sammlungen.de/ (last accessed: 25.07.2018). In addition, the first printed German fencing book entitled "Ergründung ritterlicher kunst der fechterey" was written by a Viennese free fencing master, Andre Pauernfeindt, and was published in 1516. In the beginning of the sixteenth century, the Viennese free fencers had their own guild, too. CZEIKE 1992-2004, II. 265; JAQUET-VerELST-DAWSON (eds.) 2016, 249. Unfortunately, it is not documented - at least we were not able to trace it whether the university in Vienna had such a fencing brotherhood around the 1480s or not. On the other hand, the triangles might refer to a mountainous area (thus probably to his hometown). Consequently, this coat of arms requires further research.

127 "Rette: maister/doctor Stephan Geinperger". WNStA, Ratsbuch II, fol. 31r (p29 - 1491); fol. 31v (p30 - 1492); fol. 32r (p31 - 1492); fol. 33r (p33 - 1495); WNStA, Gewährbuch I, fol. 267v (p612 - 1500).

128 The election in Wiener Neustadt is a problematic issue. In the secondary literature there is no clear-cut reference to the day of the council election. There are relevant articles in which no date is given (e.g. Hofmann 2010); in other cases different dates are quoted, usually for the early modern period: the first Sunday of Advent (RIST 2005/2007, 137, with a wrong reference to MAYER 1924-1928, II/1. 138); 4 December 1588 (LinDNER 1975, 10); 14 January 1593 (LindNER 1975, 20). In the seventeenth century, council elections could take place at different times depending on the actual date of affirmation by the ruling emperor: LINDNER 1975 , $59,234,235$. The town monographer, Josef Mayer, did not discuss the matter (MAYER 1924-1928). However, in referring to the period in which the office was held, he only provides one date, thus implying the election was on one of the last days of the previous year or on the first days of the given year, and the period of service then lasted through one calendar year. Following his lead, Gertrud Gerhartl makes similar allusions (GERHARTL 1978). It is not our task here to investigate this question further, but Geinperger's first one-year period of service as mayor (1493/1494) (with his service proven in both years) suggests that more research should be done on the election date, since Josef Mayer provided only the date of 1494 (MAYER 1924-1928, I/2. 134). Nevertheless, in our article we provide two years for the period of service only in cases when the sources we have examined ourselves verify that service indeed began and ended in two different years.

129 "Der Rath sendet den Doctor Stefan Geinperger als Bürgermeister vnd den Steinmetz Jörg Goltperger zur Regierung nach Wien um den Wiederaufbau der durch Brand zerstörten Stadt zu fördern." (26 November 1493). WNStA, Schrin II, 43. Quoted in: BoeneIM (Hg.) 1886, 37, no. 3387. "Burgermeister doctor Stephan Geinperger". WNStA, Ratsbuch II, fol. 32v (p32 - 1494).

130 "Stattcamrer maister Stephan Geinperger". WNStA, Ratsbuch II, fol. 31v (p30 - 1492).

${ }^{131}$ MAYER 1924-1928, I/2. 134 (1494, 1499); MAYER 19241928, II/1. 61 (1505-1507); Scheutz et al (Hgg.) 1997, 155 (17 July 1505 - issuer of the "Bäckergesellen Ordnung"), 121 (7 July 1505 - issuer of the "Huf- und Scherenschmiedermeistern und gesellen Ordnung"); GERHARTL 1978, 562; Vienna, ÖStA, HHStA, AUR 15 May 1506 ("Stephan Geinperger doctor etc. zu dem zeiten burgermeister" appeared as witness and issuer of the testament of Lasslau Reichenauer). 
WNStA, Gewährbuch I, fol. 305r (p673) - 26 June 1504 as a buyer of a house (see below, note 137).

132 The several tasks (offices) were either fulfilled by inner councillors or members of the "Genannt". The town had three "Schlüsselherren", two "Grundherren", one or two "Kirchenmeister", one "Spitalmeister", two "Stattkamrer" and after 1479 with the salt monopoly one "Salzkamrer", three to six "Raittherren", two "Zeugmeister", two "Baumeister", and four or five "Steuerherren". SCHOBER 1885, 225-227. For Geinperger as "Grundherr", see WNStA, Gewährbuch I, fol. 267v (p612 - 1500): "sind gruntherren worden doctor Stephan Geinperger von dem ratte vnd Cristoff Wülfing von den genanten"; fol. 274v (p626 - 1501): "doctor Stephan Geinperger vnd Sebolt Werpacher grüntherren"; fol. 283r (p643 - 1502): "doctor Stephan Geinperger vnd Sebolt Werpacher grundherren"; fol. 288r (p653 - 1503): "Gruntherren doctor Stephan Geinperger vnd Caspar Holtzer".

${ }^{133}$ As far as we can infer from the available sources, Geinperger's second term as mayor might have started only a year after the completion of the epitaph. Otherwise it would most likely have been stated that he was mayor in that year. The dominance of his figure (and his repeated coat of arms) in the painting might also have served to further strengthen his social (leading) position in Wiener Neustadt after the death of his renowned wife, "die Geroltin".

${ }^{134}$ Winkelbauer 1949. For the topography of the Kreuzhöfe, see: CzEIKE et al (Hgg.) 1982 (Städteatlas - Wiener Neustadt). Also available online: https://www.arcanum. hu/hu/online-kiadvanyok/OsterreichischerStadtatlas-osterreichischer-stadteatlas-1/wiener-neustadt-529D/ (last accessed: 15.11.2018).

135 For its location, see MaYer 1924-1928, I/2. Tafel VII, no. 46.

${ }^{136}$ MAYER 1924-1928, I/1. 423, I/2. 346-348; RIsT 1994; RIST 1998; SKVARICS 2000, 121-124.

137 "Doctor Steffan Geinperger derzeit burgermeister hie [...] ist nutz vnd gwer kommen ains hawss hie gelegen in der heiligen drivaltikeit viertl zwischen dem probsthoff vnd des pharrer zu Zemendorff hewsern [...] mit kauff von Wolfganngen Zeydenickhl von Olmüntz vnd Regina sein hawsfrawen die vormaln Wolfganngen Osterperger auch eelichen gehabt hat [...]." WNStA, Gewährbuch I, fol. 305r (p673).

138 The concerning document was issued "[...] in Steffan Geinpergers doctor etc vnd diezeit burgermaister zu gedachter Newnstat hauß in der Newnkircher gassen [...]" (8 June 1507). The document was used from www.monasterium.net (last accessed: 15.03.2018). For a summary of the document: WinNer 1962, 249-250. For the attempts to merge the bishopric with the order: WinkELBAUER 1949; GERHARTL 1978, 193-194.

${ }^{139}$ WNStA, Ratsbuch II, fol. 324v-328v (p362-370). Staub 1895, 501 (note 5); SkVARICs 2000, 238. For a general analysis of late medieval female testaments: RIST 1994 (without Geinpergerin).

14026 June 1528: "Hanns Geinperger weilent doctor Stephan Geinperger seligen beleiblicher [sic!] sone ist nutz vnd gwer komen ains hawss hie gelegen in der heiligen driualtigkeit viertel zwischen der krewtzerherrnhoff vnd Thoman Ryemer hewsern dint xij d(enarii) grundtrecht vnd nit mer. Das obegemelt hawss nach berurts seins vattern abganng erblichen lautt seiner beweisten frundtschafft an inekomen ist. [...]." WNStA, Gewährbuch I, fol. 458r (p 982).
${ }^{141}$ There are two entries in which Andre Kromer and his wife, Katherina, are named as owners of this corner house, and they still paid the sum (four schillings) to the chaplain of the hospital altar of St Elisabeth, which was established by Stefan Geinperger in 1500. WNStA, Satzbuch A, fol. $231 r$ (p321). For the entries: WNStA, Satzbuch A, fol. 270r (p399) - 28 August 1517; WNStA, Satzbuch A, fol. 271v (p402) - 17 May 1518.

14210 April 1531: "Matheus Tewfl derzeit haubtman auf Vorchtenstain vnd Appolonia sein hawsfraw sein nutz vnd gwer khömen ains hawss hie gelegen in der heiligen driualtigkeit viertl zwischen der krewtzherrn sand Geörgen ordenns hoff vnd Thomann Ryemer hewsern dint xij d(enarii) [...] das obgemelt hawss mit kauff von Hannsen Geinperger [...]." WNStA, Gewährbuch I, fol. 478r (p1022).

143 She also received a dowry from the testator: "Item meinen dieren der Gredl die ich ertzogen hab, schaff ich ain gericht pett. Mer mein plassen, grun rokh, ain schlair, vnd ain kue." WNStA, Ratsbuch II, fol. 325v (p364). "Junkfraw Margreth so obenant fraw Magdalena gescheffterin auff ertzogen hat alt bey sibentzehen jaren verhort auff all [...]." WNStA, Ratsbuch II, fol. 327v (p368).

144 "Item von erst [...] meinen leichnam hie bey vnser lieben frawen thumbkirchen am freythoff, neben der Rollen begrebnuss, gegen dem karner vber, vor vnsers lieben herren angst bildnuss, ersamenlich mit gemainer briesterschafft, berurter thumbkirchen, auch mit den vier orden, der krewtzherren sand Georgens orden, in der pharr, vnd der closter, sand Peters, sand Pauls, vnd sand Jacobs, belaidt zu der erdt bestett [...] mit gentzer oblay, zum ersten, sibenden vnd dreissigisten hailsamlich begangen." WNStA, Ratsbuch II, fol. 325r (p363). SkVARICs 2000, 48.

145 She left money not only for her burial but also for masses and for a liturgical vestment. For the latter she left a red damask dress with pearl collar, two red velvet dresses with sleeves and pearl collars, and an additional sleeve. In addition, she also donated a silk veil of five or six layers to be placed above the sacrament in the parish church of Our Lady of Wiener Neustadt, and another veil for the church of Our Lady of Zemendorf. Finally, she left one pound to each of the ecclesiastical persons mentioned when her burial was detailed. WNStA, Ratsbuch II, fol. 325v (p364). SkVARICS 2000, 104, 123.

${ }^{146}$ WNStA, Satzbuch A, fol. 231r (p321): "Doctor Stephan Geinperger lerer in der ertzney et hic hat vorsatzt sein egkhaws hie gelegenn in der newnkircherstrass neben des hochwirdigen fursten vnd herren herrn Vrban erwelter vnd bestetter zu bischouen zu Erlach vnd gegen weilennt Jorgenn Hasenndler seligen haws vber [...] dem caplan sannt Elspeten altar in dem spital hie in wyennervorstat vnd seinen nachkomen caplenen desselben altar vmb xx tal(enta) d(enariorum) vnd sol zu einer yeden qüottember dauon dienen iiij sch(illing) d(enarii) [...]." (6 March 1500). It was paid by the later owner of the house, too (see note 141). On the hospital altar of St Elisabeth: LECHNER 1965, 49, 57-58, 68, 104-106, 239.

${ }^{147}$ Between 1477 and 1520 altogether fifty-four names were listed among the confraternity members. WNStA, Scrin CXIX, Nr. 45, fol. 19. DreXLER 1955, 93 (Geinperger), Anhang (xviii-xix). For the monk, Andreas Geinperger see: JARITZ 1973, II 147-148.

148 Several witnesses appeared in front of the public notary on 30 September 1511 and reported the date and content 
of the will made on 30 July 1511. In addition, it was also recalled that after the death of Magdalena on 9 September 1511, her mother and the servant present at her deathbed were called to testify about the circumstances in which the will was left. Since the intended executors, a certain Benedict Smid and Wolfgang Prugkner, were not at home and could not come when they were urgently needed to listen to the last will of Magdalena, two other "geschefftherren", Hans Osterperger and Andre Wildegker, were present. However, the testator wanted to ensure that they would not be the guardians of her baby son. Consequently, many were involved in testifying about the bequests. WNStA, Ratsbuch II, fol. 324v-328v (p362-370).

149 "[...] haws hie gelegen in der heiligen driualtikeit virtl in der kesslerstrass zwischen der von Künigsperghawss ain ainer seitten vnd annderhalben an doctor Stephan Geinperger hawss [...]". WNStA, Satzbuch A, fol. 253r-v (p365-366).

150 Vienna, ÖNB, HS-AltD, Cod. 9221, fol. 41r, no. 5. For details on the possible location of this no longer extant grave, see later note 186 and 189.

${ }^{151}$ That both Stephan and Magdalena died within half a year suggests that the husband's death was sudden, probably due to an epidemic (this would need further research concerning plagues in Wiener Neustadt) and thus had not left a last will. The sick widow would have felt the need to rather quickly secure their baby son's inheritance, thereby preventing misuse of their estate by certain people named (see note 148).

${ }^{152}$ For the topic, see a few summaries on late medieval and early modern epitaphs: BAUCH 1976, 198-214; WECKWERTH 1957, 151-152, 156-158; ZAJIC 2004, 172-173; SCHOENEN 1967, 875; MÜLler 2011; MÉRAI 2017

${ }^{153}$ Further examples from Wiener Neustadt will be discussed later. In several epitaphs, the theme chosen relates to the actual date of death (WEILANDT 2007, 260, note 124). Although it was common for the subject matter of the painting to allude to this day, this is not the case in Dorothea Gerolt's Dormition of the Virgin, as she died on the eve of St Matthias's day (the evening before 14 May).

${ }^{154}$ There are still copies of the etching from around 1500. KEMPERDICK 2004, 260.

155 On this in general, see: Suckale 2009, 223-229 (Chapter 3: Der Meisterstich des Marientodes). In the older painting tradition, the generally narrow format of panel paintings made it rather problematic for the painters to arrange all the apostles around the death bed without overlapping each other or the central figure of the Virgin. Martin Schongauer's new composition brought a solution that could successfully cope with this problem.

${ }^{156}$ Its painter was recently identified by Robert Suckale as Hans Engelhart of Nuremberg. He posits that Engelhart had also worked as a contributor to the Schottenaltar in Vienna and received independent commissions in Wiener Neustadt and several other Austrian localities such as Sankt Wolfgang im Salzkammergut by Salzburg (the rear side of the high altarpiece of Michael Pacher) and Braunau am Inn in Upper Austria (the so-called Bäcker-altar). SuCKALE 2009, 284285. For the earlier description of the epitaph, see: RÖHRIG (Hg.) 1979, 330-331 (no. 26).

157 Wiener Neustadt, StMWrN, inv. no. B 15. On Florian Winkler/Winckler, a knight and burgher and also an imperial military leader: GerHARTL 1978, 168-170. On the epitaph: Friedrich III. Kaiserresidenz 1966, 307 (cat. no. 31), with earlier literature; SEIDL 1987, I. 77-81, II. 17-20; ButTLAR 1995, cat. no. 82; SiMON 2002, 280-289.

${ }^{158}$ HÖFler 1976, 163-172; Seidl 1987, II. 30-35; BRinKMANN-KEMPERDICK 2002, 282-295.

159 Gerhartl 1979, 132; Koller 1979, 148; Seidl 1987, I. 81, II. 21-24; SimON 2002, 353; ZeINER 2012, 64-72.

160 LANC 1983, 389.

${ }^{161}$ An overview of these works that once decorated the parish church of Our Lady in Wiener Neustadt is therefore relevant here, because - as it will be proven later - this was also most likely the original location of the Geroltin epitaph. There are also a number of works from this workshop that are preserved in various localities and countries, but in most cases the original location of those pieces is not known. Among others see, for example, SuCKale 2009, 285 (Abb. 469); Feuchtmüller 1970, 28-29. Or for the works by a member of the workshop: SARKADI NAGY 2017.

162 The epitaph of Florian Winkler is dated to 1477 and the figures of the prophets to the 1490s. GERHARTL 1979, 132; Koller 1979, 148; Seidl 1987, I. 81, II. 21-24; SimON 2002, 353; ZEINER 2012, 64-72.

${ }^{163}$ It was established in 1444 , on the site of the former Dominican friary. BENESCH 1930, 195; KüHnEL (Hg.) 1967, 107; Suida 1911-1914, III. Tafel LXX; Stange 1961, 48, 51-52, Abb. 98, 111.

164 Since 1881, the Neukloster monastery has belonged to the Abbey of Heiligenkreuz. Consequently, a considerable part of its collection, including the panels in question, were transferred and are presently preserved there. However, a larger number of the art objects once belonging to the Cistercian monastery (Stift Neukloster) of Wiener Neustadt came from the art market and arrived in the monastery after 1783 as part of P. Bernard Sommer's collection (Perger 1997, 177-183, especially 180 and footnote 19). Two of those paintings now in the art collection of Heiligenkreuz, the Flight to Egypt and the Return of the Holy Family from Egypt (Heiligenkreuz, KSH, inv. no. 319; inv. no. 318) unquestionably originated in Wiener Neustadt, as a detail of the town is portrayed in the background. Interestingly, the background of the second piece shows the Neunkirchnerstrasse (see Fig. 13) - a view from the Neunkirchnertor (BALDASS 1963, 91) - where the Glockengiesser-GeroltinGeinperger corner house (already discussed in detail above) stood (see Fig. 17). However, the origin of the Death of the Virgin panel (Heiligenkreuz, KSH, inv. no. 316) is not as obvious as it is for the previous two. Although its style suggests Wiener Neustadt could easily be its place of origin, all we know for sure is that it belonged to the collection of the Neukloster monastery. There is no unanimous agreement on its original place, function and date of creation.

${ }^{165}$ In this respect, the so-called Tryptichon-Meister and Meister der Heiligenmartyrien should be mentioned. The first master, thought to be responsible for the Calvary triptych from St Florian (found in the collection of the Augustinian monastery in St Florian in Upper Austria), was recently identified by Robert Suckale as the leading master of the workshop of the Schottenaltar (SUCKALE 2004), after his name was deciphered on the edge of the robe of the soldier Stephaton, who is shown offering the sponge to Christ. It was thus possible to identify him as the painter Hans Siebenbürger, known from various Viennese written sources. Nevertheless, 
so far no attempt has been made at an exact differentiation of the hands that worked on the above-mentioned panels, nor has a thorough analysis and identification of the painters and workshops been performed with regard to the works related to the Schottenmeister's workshop. Furthermore, no scholars have offered an explanation for the stylistic variety observed in preserved paintings identified as belonging to this stylistic circle. Again, it was Robert Suckale who has lately contributed a great deal to this topic (SUCKALE 2004; SuCKALE 2009, 186-198). In addition, see also TAKÁCS 1991. However, a number of questions still remain unanswered.

${ }^{166}$ As far as we know, that person has not yet been identified. In the scholarly literature no attention was paid to the donor, as researchers merely analysed the panel from a stylistic point of view. Wilhelm Suida raised the possibility that the person depicted could have been a doctor, basing his arguments on the identification of his patron saint as either St Cosma or St Damian. SuIDa 1911-1914, III. Tafel LXX.

167 MAYER 1924-1928, I/2. 281-283.

168 Josef Mayer also mentioned a certain master, Niklas Unger, but he is documented only in 1440 , which is too early with respect to the panel in question. For the last will of "Hainrich Hopf lerer der ercznej" (1491): WNStA, Ratsbuch II, fol. 276r-v. For the last will of his wife, Anna - already as "Anna des hochgelertten ersamen vnd weysen doctor Jorgen Taler burger in der Newenstat eeliche hausfraw" - (1496, opened in 1500): WNStA, Scrin. Nr. Z 39. For the last will of "doctor Jörg Taler vom Arnsdorff doctor der ertzney burger zu Newnstat" (1508): WNStA, Ratsbuch II, fol. 308v-310r. See also Müller 1994: 441.

${ }^{169}$ Like Geinperger, Georg Taler from Arensdorf matriculated at the university of Vienna in 1465, was promoted to the faculty of arts in 1468 (12 March), started his medical studies in 1471 (which he finished in 1476), but also taught at the faculty of arts between 1471 and 1476. For the studies of Stefan Geinperger during this time, see the sources above. For Taler: Vienna, UAW, Matrikel Wien 2, 91 (Natio Renensium, line 51) (Immatriculatio); Vienna, UAW, AFA III/1, 162 (Determinatio); Vienna, UAW, AFA III/1, 183 (Inceptio). For his teaching: Vienna, UAW, AFA III/1, 191 (1471: "Arismetricam"); Vienna, UAW, AFA III/2, 21 (1473: Examinator), 26 (1474: "De generacione et corrupcione"), 32 (1475: "De anima"), 38 (1476: Examinator), 41 (1476: "Parva logicalia"). For his medical studies: Vienna, UAW, AFM I, 98; Vienna, UAW, AFM II, 165, 173, 209 (45), 215 (48); Vienna, UAW, AFM III, 2 ("Gregorius Taler de Arenstorff in Melico Austriae residet"), 306 (61).

170 Just one year after the second term for Stephan Geinperger. GERHARTL 1978, 537.

${ }^{171}$ His will mentions among the debts to be cleared after his death: "Item von des Pöltel wegen hie bin ich schuldig 1 guldin reinisch, davon hat er von dem Gerolt von Knüttelfeld xv guldin vngrisch." WNStA, Ratsbuch II, fol. 276v. He was "Genannter" (1468) at the same time as the first husband of Dorothea Gerolt. WNStA, Ratsbuch II, fol. 9r (p5). He was also "Spitalmeister": WNStA, Ratsbuch II, fol. 21r (p9 - 1469), fol. 21v (p10 - 1470); became inner councillor: WNStA, Ratsbuch II, fol. 23r (p13 - 1473), fol. 24r (p14 - 1474); was the "Verweser des Statgerichts", namely deputy judge: WNStA, Ratsbuch II, fol. 26 r (p19 - 1480).

172 In Heinrich Hopf's last will, the first stipulation reads: "Item ich schaff mir mein begrebnüß vnder dem paradeyß vor vnnser lieben frawen pildnüß, ob der thür, vnd darzu ein epitaf, oder tafel, zumachen mit vnser lieben frawen pildnüß, sand Bartholomee, sant Erasm, vnd sant Cristoffen." WNStA, Ratsbuch II, fol. 276r. Nevertheless, the wife was to decide about the final composition of the epitaph that was prepared. See also StAub 1890-1891, I. 130-131; SKVARICS 2000, 48-49.

${ }^{173}$ In the last wills of Anna Talerin and Georg Taler there is no mention of any devotional picture or "tafel" to be made after their death, which, of course, does not mean that they did not have something made during their lifetime. Anna left fifty Hungarian guldens "zu vnser liebem frawn thümbkirchen" to the building fund ("zu dem paw") - WNStA, Scrin. Nr. Z. 39 - while Georg Taler, in his will, included a perpetual donation of six hundred pounds to the university of Vienna ("zu ainer ewigen stifft vnd stipenden der hochen schuel ze Wienn in bursa Paulj auf zerichten [...] zeordnen der Nacion Renensium") - WNStA, Ratsbuch II, fol. 309r.

174 The epitaph ordered by Alexius Funk was originally located in the parish church of Our Lady (Liebfrauenkirche). Today it is on display in Vienna, ÖGB, inv. no. 4726. For the complex relationship between the Gerolt and the Funk families, see above (and also see Fig. 16).

175 FRICK 2003, 151, W41.

176 Unfortunately, its provenance is unclear. It arrived in the museum from a private collection. Budapest, HNG, inv. no. 92.19M. For its analysis: TAKÁCS 1991.

177 ZaJIC 2004, 124, note 203.

178 KoHn 1998, 92-93, with reference to PERGER 1979.

179 Vienna, ÖNB, HS-AltD, Cod. 9221, Inscriptiones variae sepulcrales. Catalogued under this item number are two manuscripts bound together. The first one is a collection of gravestone inscriptions from all over Upper Austria. For its detailed description, see KoHN 1998, XL; ZAJIC 2009, 369371. The only inscriptions it contains from Wiener Neustadt are from the parish and cathedral church (fol. 32r-4lv). The first few related pages describe the inscriptions on the Habsburg tomb/cenotaph, which once (until 1755) stood in the choir: "zur Neustatt in der thumbkirchen afn [sic!] einer grosser castell beym chor" (fol. 32r-38r). For the Habsburg cenotaph, whose cover stone today can be found in the left side aisle, see AichingER-Rosenberger et al (Dehio) 2003, 2606. The text of the codex continues with the "andere grabschrifften in gemelter kirchen" (fol. 38r-38v). It first describes a few that must have been close to the abovementioned Habsburg memorial in the chancel (fol. 38r-v), followed by some in the vicinity of the baptismal font ("beim taufstein", fol. 38v). Two blank pages later, it continues with a description of those in the middle of the church, near to the image of Our Lady standing behind the crucified Christ ("Mitten in der kirchen bey dem eysenen schaetter ist die jungfraw Marie wie sie hinterm kreütz Christi gestanden abgemahlt und dabey geschrieben," fol. 40r). Finally, it lists a few outside the church ("Heraussen an der kirchen im freüdhoff," fol. 40v-41r).

180 ZajIC 2009. The Protestant Preuenheuber supposedly studied in Graz, later worked in Steyr, then, during the campaigns against the Protestants, fled to Regensburg, but afterwards returned to Austria. His work entitled Castrum Styrense was published there. Another, the Annales Styrenses, was given as a manuscript by his widow to the town of Steyr. OFNER 1966, 63-64; ZAJIC 2009, 388-389. 
${ }^{181}$ The only exception is an altar that relates to a painter of the king (later emperor) Frederick III: "Anno Domini 1447 obÿt der erbar maÿster Hanns Wohlgenant, der des rom(ischen) kaysers mahler gewesen ist, dem Gott gnad, vnd die tafell ist gemahl worden im 55 jahr und des altar ist geweiset in den ehren St Procopÿ, St Vlrich, St Elen(us), St Ruprecht, St Virgil." Vienna, ÖNB, HS-AltD, Cod. 9221, fol. $38 \mathrm{v}$, no. 1 . It is also worth quoting here the full entry, since this medieval altar of the parish church is not mentioned in the scholarly literature - at least Josef Mayer or Helga Skvarics, who in their works listed all the medieval altars, including their first appearance in the sources, did not make any reference to it: MAYER 1924-1928, I/2. 323-340; SKVARICS 2000, 117.

${ }^{182}$ In addition to these panels, which were identified in several collections, several others must have decorated the inner space of the late medieval parish church. We have at our disposal a considerable number of last wills in which the testators refer, sometimes in great detail, to their desired place of burial (SKVARICS 2000, 43-61) and, in several cases, also to a painted memorial panel they wanted made and placed above their tombs. For example: BoEHeIM (Hg.) 1886, IV/2. no. 3146 (1456), no. 3296 (1478), no. 3355 (1483), no. 3378 (1491), no. 3379 (1491), no. 3406 (1507), no. 3608 (1560).

183 "Anno Dom[ini] 1498 am freitag St. Matthias abent ist gestorben die ersam frauw [sic!] Dorothea Geraltin und des wolgelherten Steffan Hainperger lehrer in den sieben freÿen künsten und in der artzneÿ burgers zu der Neustatt ehliche hausfraw gewesen ist, der Gott gnadt." Vienna, ÖNB, HSAltD, Cod. 9221, fol. 38r, no. 4. The inscription quoted in the codex does not match exactly to the text of our epitaph. On the one hand, this could simply be due to the inaccurate work of the copyist (as Renate Kohn surmises when she quotes the text of the codex and identifies it with that of the epitaph, KOHN 1998, 92-93). On the other hand, the slight differences could also mean that the copyist did not reproduce the text of the epitaph but that of the grave slab. Although inaccurate copying is a plausible explanation, given that the other texts in the codex were taken from tombstones, the second option is more likely. While in many cases the text of the grave slab starts with words such as "hic iacet" or "hie leyt/ligt begraben", there are many other examples that do not correspond to this rule: for example, the text on a gravestone belonging to a relative of the Gerolt family and still visible in the parish church of Knittelfeld (recent photo by Judit MAJOROSSY) reads as follows: "Anno Domini MCCCCC ${ }^{\circ}$ II an Sand Kathrein tag ist gestorb(en) der ersam Gothart Mürrer dem Got gnadig sey."

${ }^{184}$ The grave slabs of the church of Our Lady were partially elevated and placed along the walls of the church during its Baroque renovation in the eighteenth century (around 1755, under the episcopacy of Ferdinand Graf von Hallweil, 1741-1773). However, only those considered more interesting at that time were presented this way. The rest were either cleared away from the church or left in their original places on the floor and covered by the new, Baroque ground level. See Aichinger-Rosenberger et al (Dehio) 2003, 2603. During the excavation in the 1970s, unfortunately only a few medieval (basically fourteenth-century) gravestones were found in secondary usage. See the several archaeological reports: FARKA 1977; FARKA 1978; FARKA 1979.
${ }^{185}$ In 1628, the large wall painting of St Christopher, which had been commissioned by Emperor Frederick III in 1493 and was located on the northern wall of the sanctuary (GERHARTL 1978, 186; KoHN 1998, 91, Taffel XXI, Abb. 55), was whitewashed (Koller 1979, 147). This is also the same period (during the episcopacy of Melchior Khlesl [1588-1630]) when the prophet and apostle figures in the nave (completed around the 1490s) were repainted and a number of new Baroque altars were founded. BUTTLAR-ELBERBERG 1997. The new ambo was finished in 1608-1609, and several early modern Baroque epitaphs were placed in the church. Thus, a sort of restoration of the interior, an early Baroque re-decoration, must have taken place by this time. GerHArTl 1979; Koller 1979. Aichinger-Rosenberger et al (Dehio) 2003, 2607, 2608-2610, 2610-2614

186 The following text appears a few pages after the entry on Dorothea Gerolt: "Anno Dom[ini] 15[... - with dots, space was left out] ist gestorben der hochgelährt Stephan Heinperger doctor burger zu der Neustatt, dem Gott gnad." Vienna, ÖNB, HS-AltD, Cod. 9221, fol. 41r, no. 5. The former existence of the gravestone was also mentioned by Renate Kohn, who, citing the text from the codex (KoHN 1998, 109), noted that the last two ciphers of the year are missing; they were either illegible or were never completed (she considers the latter more plausible). Thus, the gravestone and its inscription might have been ordered and made before his death, and the exact year was never added later. For a possible explanation (since the widow also died soon after him), see the discussion in the main text above about Stefan Geinperger's death.

187 GerHARTL 1979, 130-131. For the excavation of the Gruft and its description: FARKA 1977, 554; FARKA 1978, 30; FARKA 1979, 139; REIDINGER 2001², 355-362.

${ }^{188}$ For the beginning of the bishopric and its first bishop: MAYER 1924-1928, I/2. 306-307, 314-317. For Engelprecht's activity, see also: GERHARTL 1978, 172-174, 183184. For the description of the gravestone: RöHrIG (Hg.) 1979, 330 (no. 25); KoHn 1998, 89-90, Tafel XX, Abb. 51. For its possible medieval and present location in the church, see Fig. 18.

189 Although it is just a hypothesis, it is still a telling detail that the burial place of Stephan Geinperger's second wife could be located not very far from the same entrance, outside the church by its wall (see Fig. 18). "Magdalena weilent des hochgelerten doctor Steffan Geinperger burger hie zu der Newenstat seligen gelassen witib" in her last will written on 30 June 1511 stated that "meinen leichnam hie bey vnser lieben frawen thumbkirchen am freythoff, neben der Rollen begrebnuss gegen dem karner vber, vor vnsers lieben herren angst pildnuss". WNStA, Ratsbuch II, fol. 324r-328v. With the help of Johann Nepomuk Fronner's work documenting the text and location of several epitaphs and memorials that were later moved to a new place (FRONNER 1836), it was possible to determine the original location of the grave slab of Anna Roll, the wife of Hans Roll from Straßburg: next to the southern entrance on the outside wall of the church and later relocated to the inner wall of the northern side nave by the entrance, where it is still visible today. See KонN 1998, 36 (Anna Roll, †1451), 87-88 (Hans Roll, †1489), and Tafel LIV. At the same time, although the memorial slab of Bishop Engelprecht was not moved between 1836 and 1997 (KoHN 1998, Tafel LIV), its medieval location might 
have been closer to the contemporary main altar and the Habsburg Gruft in the sanctuary.

${ }^{190}$ For the excavations in detail: FARKA 1977; FARKA 1978. As a summary: FARKA 1979. The gravestones of Hippolyt Steiner (died 1506) and Marx Treitzsaurwein (died 1527; for his will: SKVARICS 2000, 49-50) were found not far from their supposed medieval locations (see Fig. 18). Hippolyt Steiner was buried by the medieval altar of St Andrew, which was thought to be somewhere in the vicinity of the northern entrance to the transept (see above, note 99). For the possible medieval location of the second grave: RöHRIG (Hg.) 1979, 334 (no. 33); Gerhartl 1979, 132-133. There are only two graves with no further descriptions in the excavation material, namely graves no. 3-4 in the crossing (FARKA 1977, 556, Abb. 501; FARKA 1978, 35, Abb. 35). However, no grave goods were found that could offer any further assistance. In addition, the description of the nineteenthcentury restoration offers no relevant details concerning late medieval burials (STAUB 1894; StAUB 1899).

${ }^{191}$ In most cases, painted epitaphs are found in the immediate vicinity of the gravestones, if not exactly by the grave itself. This is why their texts do not usually refer to the burial place but to the date of death, in contrast to many gravestones whose inscriptions often begin with the phrase "hic iacet". For further information on this: WeILANDT 2007, 247 (note 35). A special, but not at all unique case, was the epitaph for Florian Winkler, the text of which reads: "Anno $\mathrm{D}$ [omi]ni $\mathrm{M}^{\circ} \operatorname{cccc}^{\circ}$ lxxvijo iar an sand Matheus abent starb der edl hest [sic!] Florian Winkchler vnd ligt da pegraben dem Got genedig sey." BoeHeIM 1889, 93-94; GerHARTL 1967, 136; KoHN 1998, 77-79. Nevertheless, epitaphs can also be placed in a completely different location, as happened, for example, in the case of the already-mentioned Alexius Funk. As a burgher of Wiener Neustadt, on a journey in 1521, he suffered a sudden death and consequently was buried in Memmingen, in his town of origin, where his tombstone is still visible in the family chapel of the church of St Martin. This happened even though in his last will, which was written in 1515 (WNStA, Ratsbuch II, fol. 353v$355 \mathrm{v})$, he stated that he wished to rest in Wiener Neustadt and also arranged for an epitaph above his grave in the church of Our Lady. This was finally made and placed in the Liebfrauenkirchen and today is preserved in Vienna (Vienna, ÖGB, inv. no. 4726). For the almost complete edition of his last will, see PickL 1966, 393-396. See also: AnkwiczKleEHOVEN 1955, 49-51, Abb. 5 (the gravestone).

192 Nevertheless, as mentioned earlier, there is no written evidence (so far) that refers to the burial place or tomb of Hans Glockengiesser. His testament has not survived in the town protocols either (SKVARICS 2000, 237-247, the list of the medieval testators of Wiener Neustadt). The single piece of evidence on his death is a reference to his being deceased in 1488 in the Ratsbuch of Wiener Neustadt (WNStA, Ratsbuch II, fol. 29v) and that masses were commissioned for him in the parish churches of St Sebald and St Lawrence in Nuremberg (see note 112). The fact that masses were celebrated for his soul by his family and kin does not exclude the possibility that his actual burial place was not in Nuremberg; it could have been in Wiener Neustadt.

193 See, for example, the case of Margarethe Hayd (WEILANDT 2007, 255). In the Kingdom of Hungary, according to the statutes of ecclesiastical synods (for example, the synod of Veszprém), a wife was allowed to choose her own burial place, but if she did not do so, she was automatically buried next to her ex-husband ("si sine electione sepulture obierit [...] in sepulchre viri premortui tumuletur"). Quoted in: Majorossy 2011, 116 (note 73). In wills from late medieval Pressburg, there are a few examples of remarried burgher women who explicitly wished to be buried by their earlier deceased husbands. For example, Barbara, the wife of Sebastian Eichenreich, wanted to be buried by Hans Plantscher, her "hawswirdt saligen", while the second husband was buried together with his own second wife, Margareth, as was revealed in her last will. MAjorossy 2011 , 116-117. For examples from Wiener Neustadt: SkVARICS 2000, 47-52, especially 47 (although there are no explicit cases mentioned of remarried women wishing to be interred next to their former husbands. However, the author states that this custom must have been the most common).

${ }^{194}$ As mentioned, Valentin Preuenhueber's manuscript informs us that he was finally buried outside the church, most probably on its southern side, close to the wall of the sanctuary. Vienna, ÖNB, HS-AltD, Cod. 9221, fol. 41r, no. 5 (see note 186). There are only a limited number of inscriptions from outside the church, despite the presence of the graveyard all around. Furthermore, a considerable number of gravestones that had originally been located there are presently preserved inside the church (KOHN 1998, Tafel LIV). Thus, it is highly probable that the person who copied the inscriptions limited his activity to those gravestones situated along and close to the wall. On the one hand, unfortunately, nothing more is known about the appearance of Geinperger's gravestone; only its inscription was transmitted. On the other hand, since his second wife was buried by the entrance (although not described by Preuenhueber) next to the Rolls, he presumedly rested next to his second wife.

195 Such information is preserved, for example, in Nuremberg: WeILAND 2007, 247.

${ }^{196}$ It is comparable in size to the other few preserved (that we know of) painted memorials of significance from Wiener Neustadt, from the church of Our Lady. While the Geroltin epitaph measures $180 \times 120 \mathrm{~cm}$ in its original frame, the Winkler epitaph is of similar height but narrower, measuring $188 \times 89 \mathrm{~cm}$ (see notes 157 and 191), and the Funk epitaph is considerably smaller, at $151 \times 94 \mathrm{~cm}$, but it is preserved without the inscription part (see note 174). Finally, the so-called St Lambrecht votive panel (the Walach epitaph) also corresponds in size, measuring $179 \times 141 \mathrm{~cm}$ in its original frame (see note 11).

197 On the value and appreciation of painted epitaphs, see WEILANDT 2007, 246 (with examples from Nuremberg). In 1458, Margarethe Hayd's epitaph cost around twenty-five guldens and was considered an expensive piece, while another Bildepitaph in 1512 cost only fourteen and a half guldens. As a comparison, a liturgical ornate donated by Sebald Schreyer in 1492 was worth one hundred and sixty-seven guldens. For further examples, see also SCHOENEN 1967, 898 The costs of such memorials, however, could be quite wideranging. In Pressburg, for example, the most expensive gravestone was ordered for fifty golden florins by Niklas Jung from Neusohl ("zu ainem stain auf mein grab L fl."). MAjOROssY 2011, 111 (note 58). Meanwhile a Totenschild in Nuremberg could be purchased for three florins. ZAJIC 2009, 181. 
198 WeCKWERTH 1957, 172-175; WeILANDT 2007, 253; Zajic 2004, 172-180; SCHOENEN 1967, 875.

${ }^{199}$ This might happen at least in cases when the woman outlives both her husbands and orders an epitaph for herself. However, when the husband is responsible for ordering a memorial to the deceased woman, the attitude might be different - as in our case. In Nuremberg, the majority of late medieval painted epitaphs were commissioned for women. The reason might be that men had another type of memorial image, a funerary hatchment, the so-called Totenschilde. Consequently, only those men of lower social rank, who thus did not have the right to place a Totenschild in the church, commissioned a Bildepitaph for themselves. WEILANDT 2007, 243-246, 247sqq.

${ }^{200}$ For example, two pieces in the collection of the Stadtgeschichtliches Museum Leipzig, the memorial panel of Ulrich Lintacher and his family from 1525 (inv. no. Kirchliche Kunst Nr. 20), or the epitaph of Cunz Preusser from around 1520 (inv. no. Kirchliche Kunst Nr. 25).

201 Such a case was analysed by Corine Schleif and Volker Schier concerning the Holzschucher-Imhoff-Tetzel epitaph (SCHLEIF-SCHIER 2009). The epitaph was made around 1520 by an artist in Albrecht Dürer's circle for Ursula (born as Holzschuher) Imhoff Tetzel, who died in 1504, and is still visible in the church of St Sebald in Nuremberg. In its final version, the painting depicts both husbands on the heraldic right-hand side, the earlier deceased Paul Imhoff and the surviving Nikolaus Tetzel. Nevertheless, with the help of infrared photography, it became clear that originally only one of them was represented in the epitaph. The authors leave the question open whether the Tetzel relatives were offended by the first version, because it did not depict the more recent husband, or the Imhoff daughters protested because the painter had not included their earlier deceased father.

${ }^{202}$ For example, the epitaph of Barbara Tucher in the church of St Sebald in Nuremberg, which was finished sixteen years after her death (WEILANDT 2007, 253), or the epitaph of Ursula Imhoff Tetzel, which was made sixteen years later (see note 201).

203 On the topic, see ScHoENEN 1967, 875. In addition, for example, a testator, the blacksmith Wentzla Hakchl from Wiener Neustadt, ordered in his last will, written in 1483 , that after he died an already available painting should be used as his epitaph and his previous wife and their children should also be depicted on it. For the will: WNStA, Ratsbuch II, fol. 252v. Also quoted in: Boeneim (Hg.) 1886, IV/2. no. 3355.

${ }^{204}$ Weilandt 2007, 253. The son, Nikolaus, who appears in the above-discussed epitaph of Barbara Tucher (see note 202), was married years after the memorial to the mother was made. Nevertheless, he was depicted with his and his wife's common heraldic shield (Allianzwappen); this was unquestionably a later addition to the original image.
Consequently, in such cases, the epitaph becomes a sort of pictorial family chronicle. An additional example is the Thanhauser epitaph from the parish church of St John of Neumarkt in der Oberpfalz (most likely also produced in Nuremberg in 1497), whose image is available in the Virtuelles Museum Nürnberger Kunst online: https://museumnuernberger-kunst.de/projects/show/513-thanhauser-epitaph (last accessed: 15.09.2018). A similar case is the alreadymentioned female epitaph from Wiener Neustadt, commissioned by Sigmund Walach for his wife (see note 11). The panel was undoubtedly painted prior to his wife's death in 1434. However, the second part of the inscription was most probably added later, after Walach's own death in 1450. KOTKOVA 2007, 97; OBERHAIDACHER 2012, 231.

${ }^{205}$ In the epitaph of the Ayrer family in Nuremberg (GNM, inv. no. GM 547), the departed members of the family were marked with a little cross above their heads. See also the epitaph-altar of the von Trauttmansdorf family in the church of St Corona in Leiben. ZajIC 2004, 178.

${ }^{206}$ In general, dendrochronology may provide deeper insight into the dating of any artwork made of wood. However, the investigation on this epitaph by Dr András Grynaeus (Hungarian Dendrochronological Laboratory) did not produce any clear results. Unfortunately, the wooden boards of the panel were cut from a part of a silver fir trunk close to the heartwood and therefore contained only the juvenile growth-rings; consequently, accurate dendrochronological dating was not possible.

${ }^{207}$ Knowing the blazon of the Nuremberg branch of the family is important if we are to accept the identification of Hans Glockengiesser suggested above. It is depicted on the Glockengiesser epitaph, among others, in the parish church of St Lawrence in Nuremberg (and shows a bell in a red field rather than the dagger known from the Geroltin epitaph). It was made for Agnes Scherp/Scharpf, the first wife of Hans (I) Glockengiesser, who died in 1433 (25 July) and who must have been the grandmother of Johannes Glockengiesser "kaiserlicher Rat", who worked in the court of Emperor Frederick III. In the Nürnberger Künstlerlexikon it is also stated that this Johannes Glockengiesser arranged a new, imperial coat of arms for his father (Konrad Glockengiesser) and brothers (Andre, Hans [II], Peter and Stefan Glockengiesser). Grieb 2007, I. 480. For his father: WACHAUF 1972, 33, no. 62. On the several members of the Glockengiesser family, grandparents, parents and brothers: GRIEB 2007, I. 480-481. On the family memorial practices in Nuremberg: STAUB 1995.

${ }^{208}$ Even with the help of the written material - as discussed above - it can be stated with certainty only for the three who survived and were documented at the time of the mother's second marriage (see note 86).

${ }^{209}$ Most recently on stepfamilies in visual culture: WARNER 2018. 